\title{
Bedforms and their Hydrodynamic Interpretations from the Thakuran Drainage Basin of the Sunderbans, Eastern India
}

\author{
Gautam Kumar Das \\ Department of Chemical Engineering \\ Jadavpur University, Kolkata- 700 032, India \\ Email: gautamkrdas@yahoo.com
}

\begin{abstract}
The exposed portions of the Thakuran River bed and the intertidal mid channel bars revealed various bedforms of tidal origin. Sand flats with small and large-scale bedforms dominate over the downstream portion of the shoals whereas; mudflats are with less physical structures. The presence of megaripple marks and ripple marks as bedforms indicates that the river goes up to the upper part of the lower flow regime. Both the surface and internal structures are indicative of tidal influence. Surface structures like small ripple marks, linguoid ripples, megaripples, sandwaves, rill marks, rhomboid marks etc. are recognized. Internal structures like flaser and lenticular type is highly indicative of flood and ebb cycles. Zones with distinctive bedform characteristics can be delineated based on their morphological variations and orientations. Moreover, $5-15 \mathrm{~cm}$ wide intertidal belts are populated by hybrid bedforms. The structures indicating modification of bedforms due to fluctuating velocity and depth with ebb and flood periods include i) skewed spurs, ii) ripplefans, iii) flat-crested megaripples and sandwaves, iv) dissected channels and v) microdeltas.
\end{abstract}

Keywords: Bedforms, Ripples, Megaripples, Sand waves, Ripplefans, Rill marks, Rhomboid marks, Skewed spurs, Flaser bedding, Swash marks, Backwash marks

The Thakuran River channel in the Hugli-Matla estuarine complex of northeast India (Fig. 1) experiences semi-diurnal spring tidal range above $5 \mathrm{~m}$ near the mouth (Das, 2015). The tidal prism covers the entire $80 \mathrm{~km}$ length of the river. Most of the sediments of the river are recycled by tidal currents under extreme paucity of fresh water discharge from the headland except for the monsoonal months. The intertidal sand flats are ornamented by bedforms of various kinds and scales. Several scales of unsteadiness are marked in the tidal process. Among many such processes the following are the most important: i) fluctuations in water depth and velocity associated with ebb and flood periods, ii) flow reversals associated with ebb and flood, iii) neap and spring tidal flow variations, and iv) seasonal tidal variations with equinoctial cycles. A single bedform type and the assemblage of bedform populations display features due to one or more of these scales of unsteadiness at a particular point of time. Thus bedforms in a tidal situation often exhibit a quasi-equilibrium form under effects of unsteadiness.

With a purpose to examine the internal manifestations of bedforms generated of the mid channel bars several L-shaped trenches were dug during the time of emergence. Megaripples bedding, parallel stratification, horizontal stratification, reactivation surfaces in 
cross-bedded units and penecontemporaneous deformation structures have been encountered as internal structures.

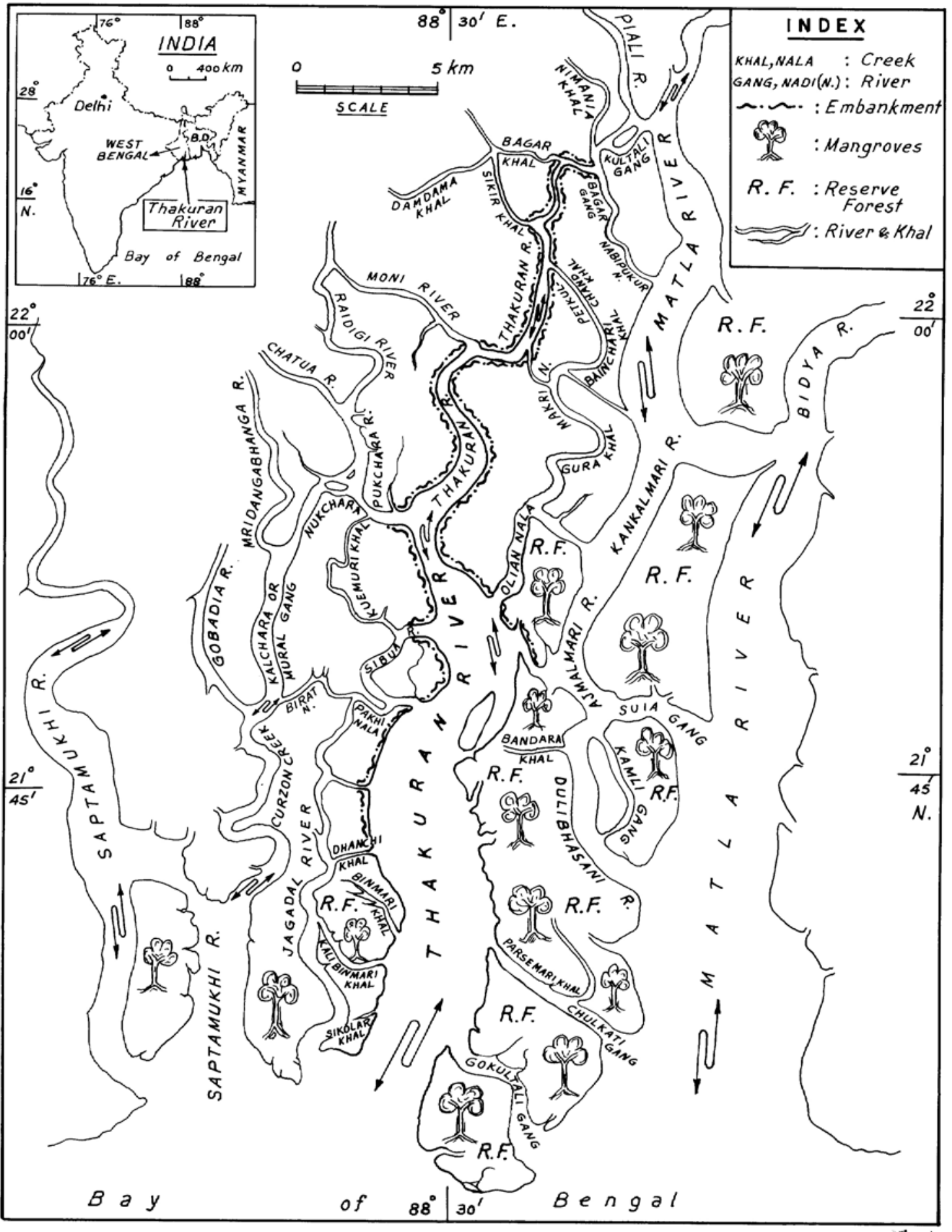

Fig. 1: Map of the Thakuran River with its connective drainage networks. 
Ripples and megaripples originated in mesotidal and macrotidal estuaries have been described by many workers (e.g. Van-Straaten, 1950, 1961; Klein, 1970, 1971, 1977; Boothroyd, 1978). But studies on intermediate and large-scale transverse bedforms like megaripples and sand waves originated in the macrotidal settings are relatively few. Further, they cannot be duplicated in laboratory flumes. The only known classical studies of such large-scale bedforms in natural settings are obtained from the Bay of Fundy, Canada (Dalrymple et al. 1975, 1978, 1990) and the Loughor estuary, South Wales, UK (Elliott and Gardiner, 1981). The morphology of bedforms studies in the meso-macrotidal Thakuran River, that with some exceptions closely resembles those described by Dalrymple et al. $(1978,1990)$ and Elliot and Gardiner (1981).

Flume experiments with steady flow conditions have been used extensively for theoretical understanding of bedform mechanics (Simons and Richardson, 1961, 62; Simons et al. 1965). But the large-scale natural flows and their unsteady nature limit the applicability of flume data (Allen, 1973; Jackson, 1975; Middleton and Southard, 1978; Dalrymple et al., 1978). The present work in a meso-macrotidal river system has renewed the stimulus for studying bedforms produced by large-sale unsteady flow in natural settings. The sand dominated middle to lower stretch of the river has become significantly important in this respect where the intertidal sand bodies with numerous bedforms of different scales get exposed after each ebb tide. Observations in the field were only possible during the span of time following ebb tides and advent of flood tide.

\section{Bedforms Characters}

Field study for years revealed that the bedforms, though not static, are permanent features. An individual bedform zone is a reflex of the prevailing tidal domain in the area. The tidal domains have a general tendency of shifting their positions and these, in turn, change the bedform characteristics of a particular locality (Das, 2016). The bedform zones and the interzonal areas are thus dynamic features.

Inherent unsteadiness and reversals of tidal currents as well as bedform-current interactions also cause frequent changes in bedform architecture. Smaller bedforms quickly change their orientations, but large sandwaves do not, in response to flood-ebb change over (Dalrymple et al., 1978; Boothroyd, 1978). The following deliberation presents an account of bedforms, generated in the meso-macrotidal Thakuran River, as comprehensively as possible.

\section{Sedimentary Structures on the Mid Channel bars}

Three different scales of bedforms are recognizable in the mid channel bars of Pachim Sripatinagar of the Thakuran River (Fig. 2) viz. the small-scale, the intermediate-scale and the large-scale and these have been classified based on the scheme of Reineck and Singh (1980). The small-scale bedforms include all varieties of ripples, the intermediate-scale embodies two different megaripples types and the large-scale features comprise the sandwaves (Table$1)$. 
Open access e-Journal

Earth Science India, eISSN: 0974 - 8350

Vol. 9 (II), April, 2016, pp. 53 - 103

http://www.earthscienceindia.info/

\section{Megaripples}

\section{Straight-crested Megaripples}

The mid channel bar surface is extensively sculptured by trains of straight-crested megaripples. These megaripples are two dimensional forms with low height $(\mathrm{H})$ ranging between 0.15 and $0.43 \mathrm{~m}$, moderate wavelength (L) ranging from 4.6 to $12.3 \mathrm{~m}$ (Fig. $3 \mathrm{E}$ ) and long span ranging from 5.9 to $13.7 \mathrm{~m}$ (Table-1). They are parallel to each other over considerable distances (Fig 4) but exhibit minor sinuosity (Fig. 5). These megaripples show broadly convex-up profiles and their crestal heights remain more or less constant without showing any well-developed scour pits in the troughs. The troughs contain small ripples with crestal orientations perpendicular to the megaripples crests. This is because of the generation of a secondary flow pattern along the troughs of megaripples during falling water level.

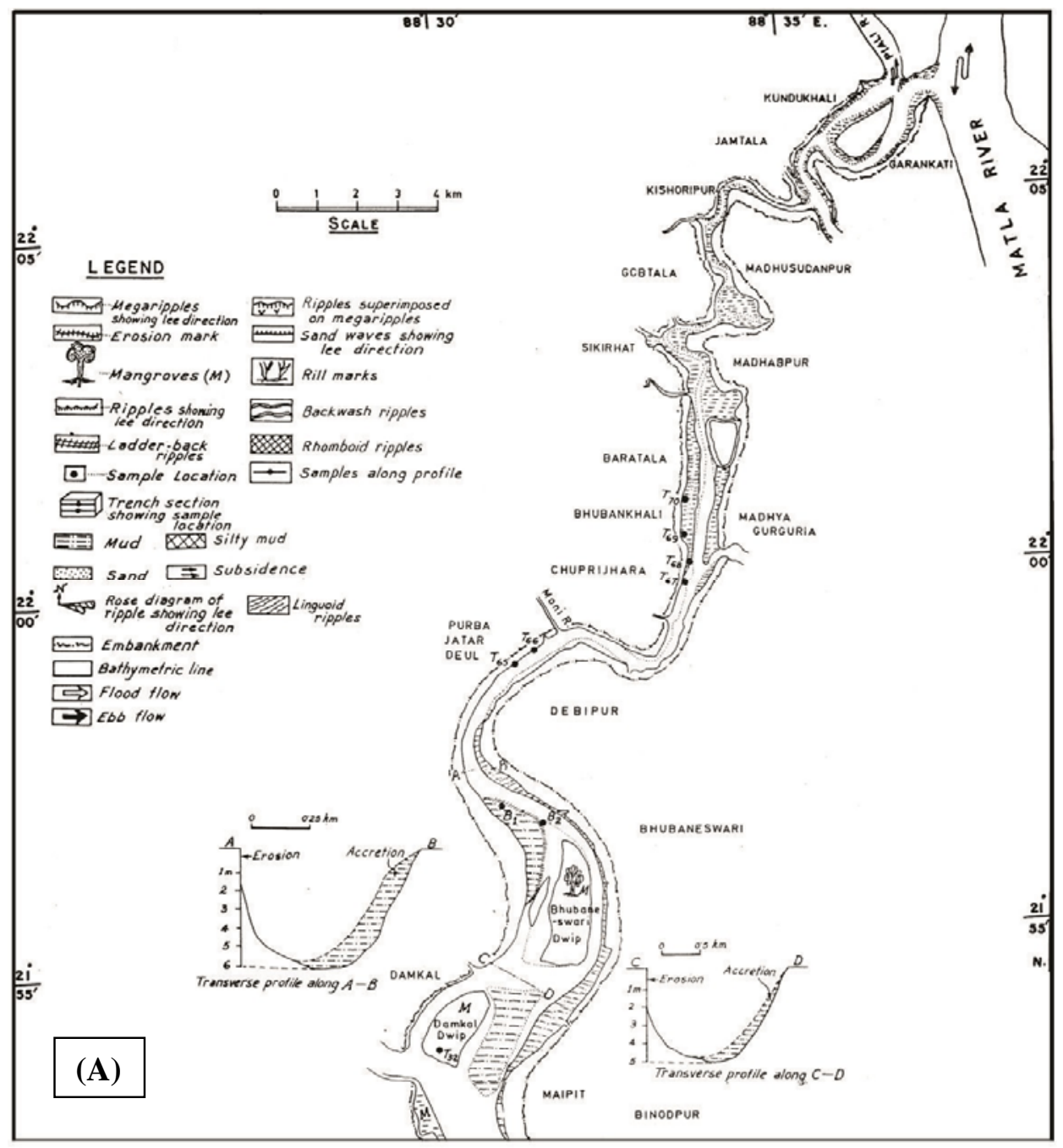




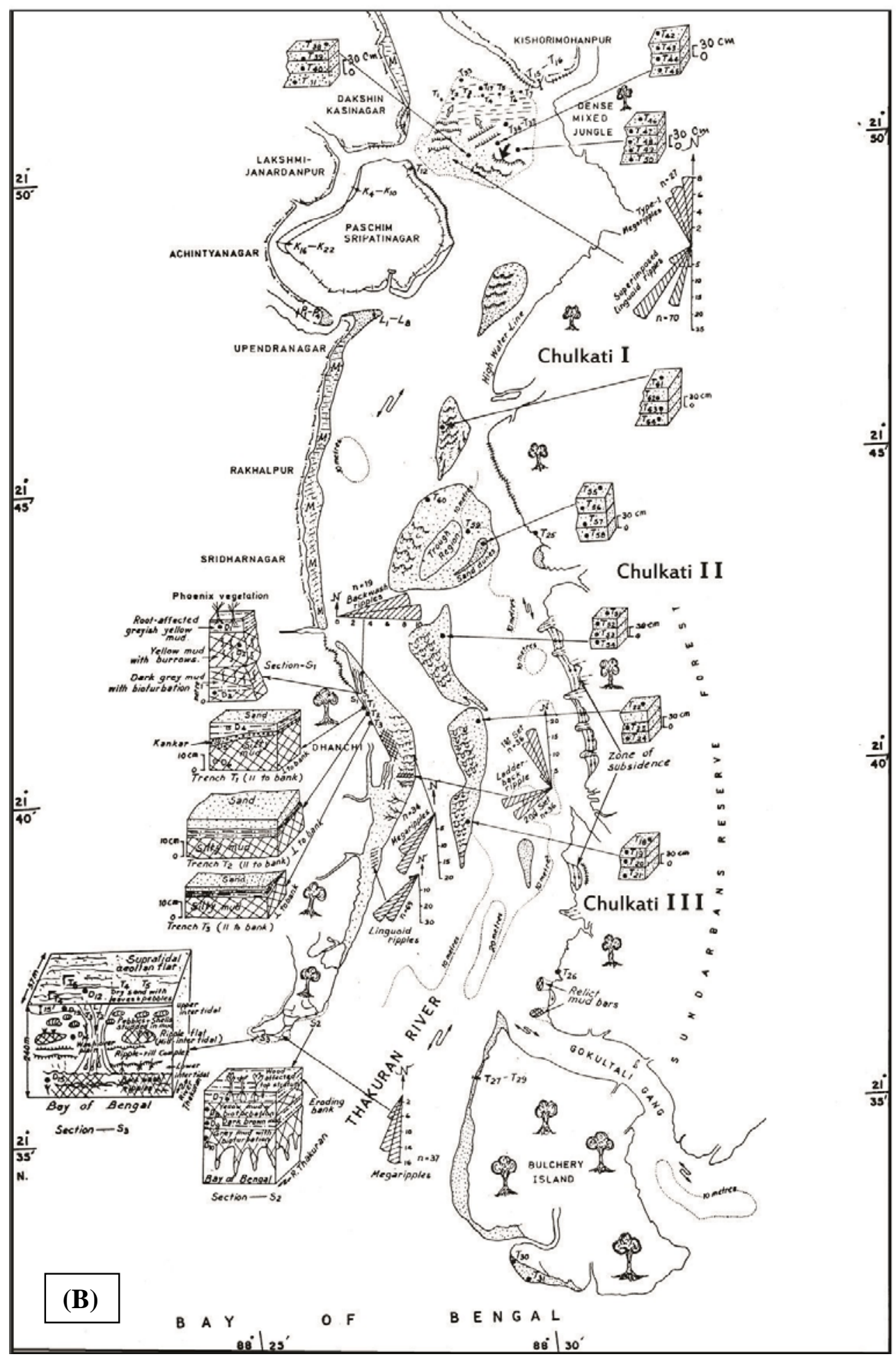

Fig. 2 (A\&B): Geomorphological and Sedimentological map of the Thakuran River showing sample locations. 


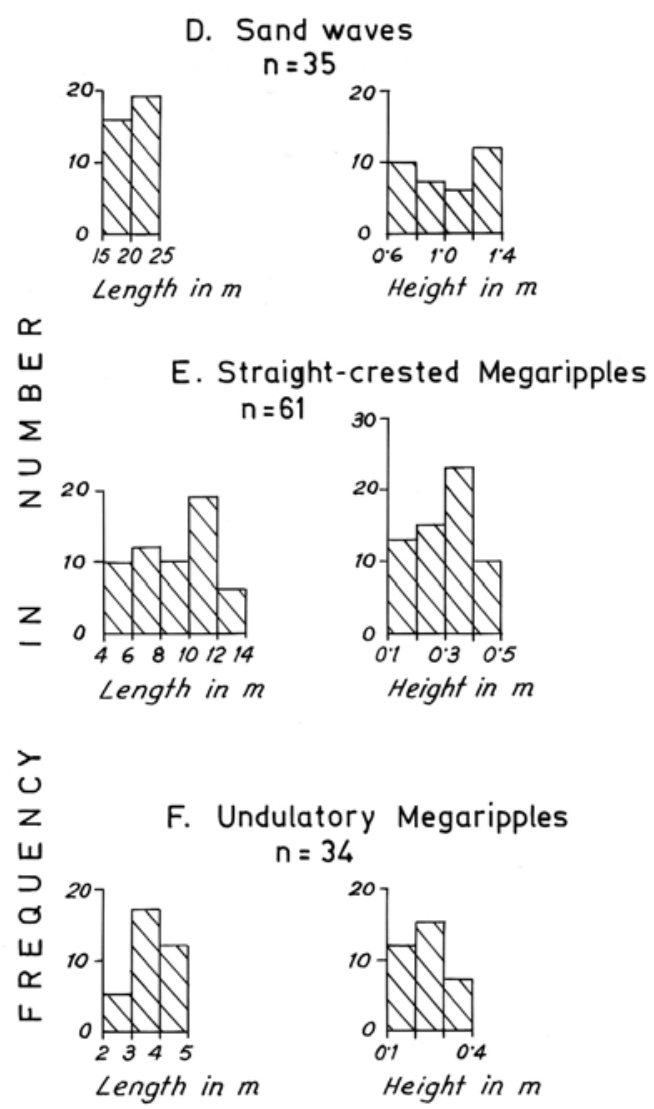

Fig. 3: Histograms of distribution of Length and Height values of sandwaves, straight-crested megaripples and undulatory megaripples

The $\mathrm{L} / \mathrm{H}$ ratio of the megaripples ranges from 14.87 to 57.14 . Wavelength versus height maintains a definite correlation (Fig. 6A). The graphic mean size $\left(\mathrm{M}_{\mathrm{Z}}\right)$ of these megaripples ranges from 2.45 to 2.96 phi with a mean of 2.66 phi. Trench sections on mid channel bars often reveal intact preservation of crests and troughs of megaripples (Fig. 7, 8, 9 \& 10).

The lee slope amount of the megaripples near the crests was around $32^{\circ}$, whereas, near the base the angle is reduced to around $10^{\circ}$. However, in areas where these bedforms are modified by a change in flow direction with falling water level, several spurs emerge out from the slip-faces which are further mantled by ebb-oriented, falling-stage ripple-fans (Figs. 11, 12, 13 and 14). The ripplefans are modification structures in front of slip-faces and are formed by the formation of helical flow-cells in between the spurs (Allen, 1984). These megaripples are formed at somewhat lower velocities (max. velocity of $70 \mathrm{~cm} / \mathrm{sec}$ and water depth of $2 \mathrm{~m}$ ) than that required for the undulatory or lunate megaripples (Dalrymple et al., 1978; Reineck and Singh, 1980). In some instances small-scale wave ripples climb over the megaripples or interfere with their crestal trains (Figs. 15 and 16). 


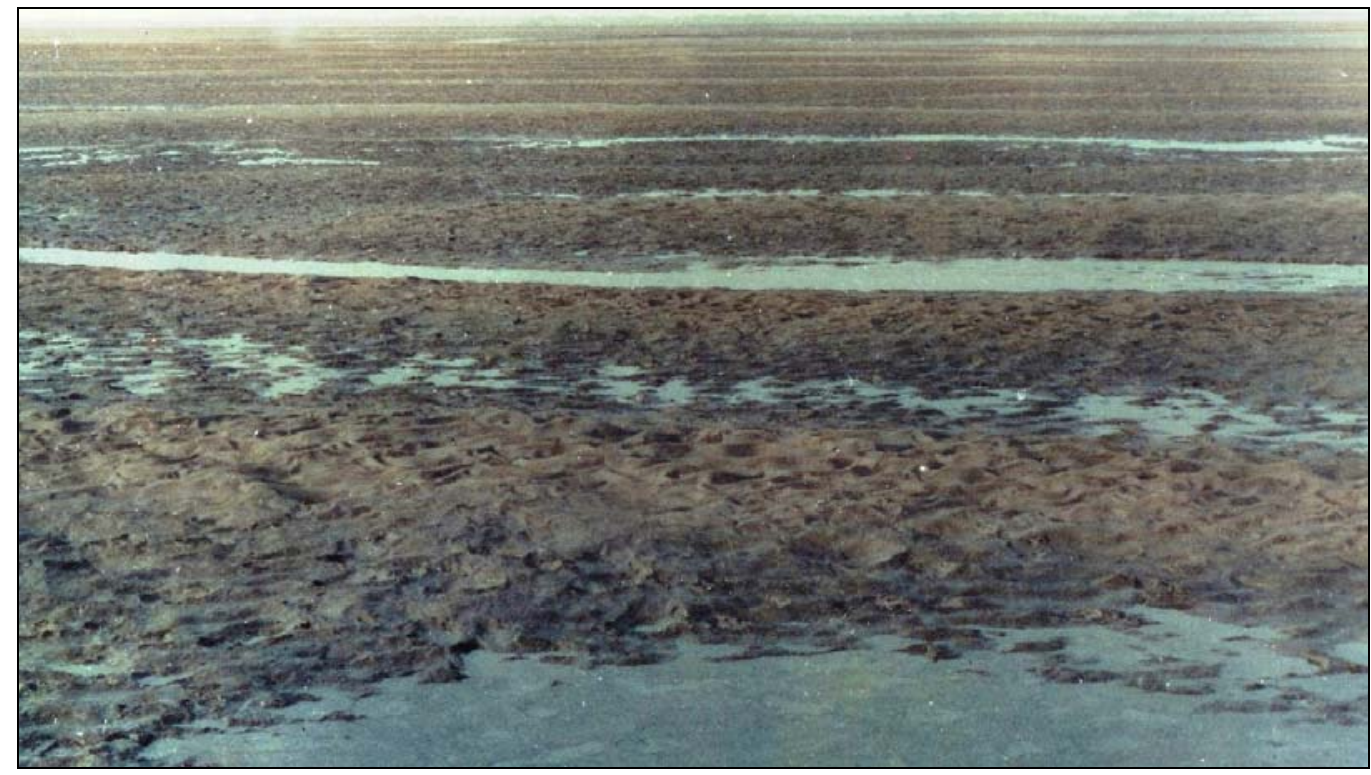

Fig. 4: Typical appearance of straight-crested megaripples (Type-I). Note the straight crests, constant crestal heights and lack of scour pits.

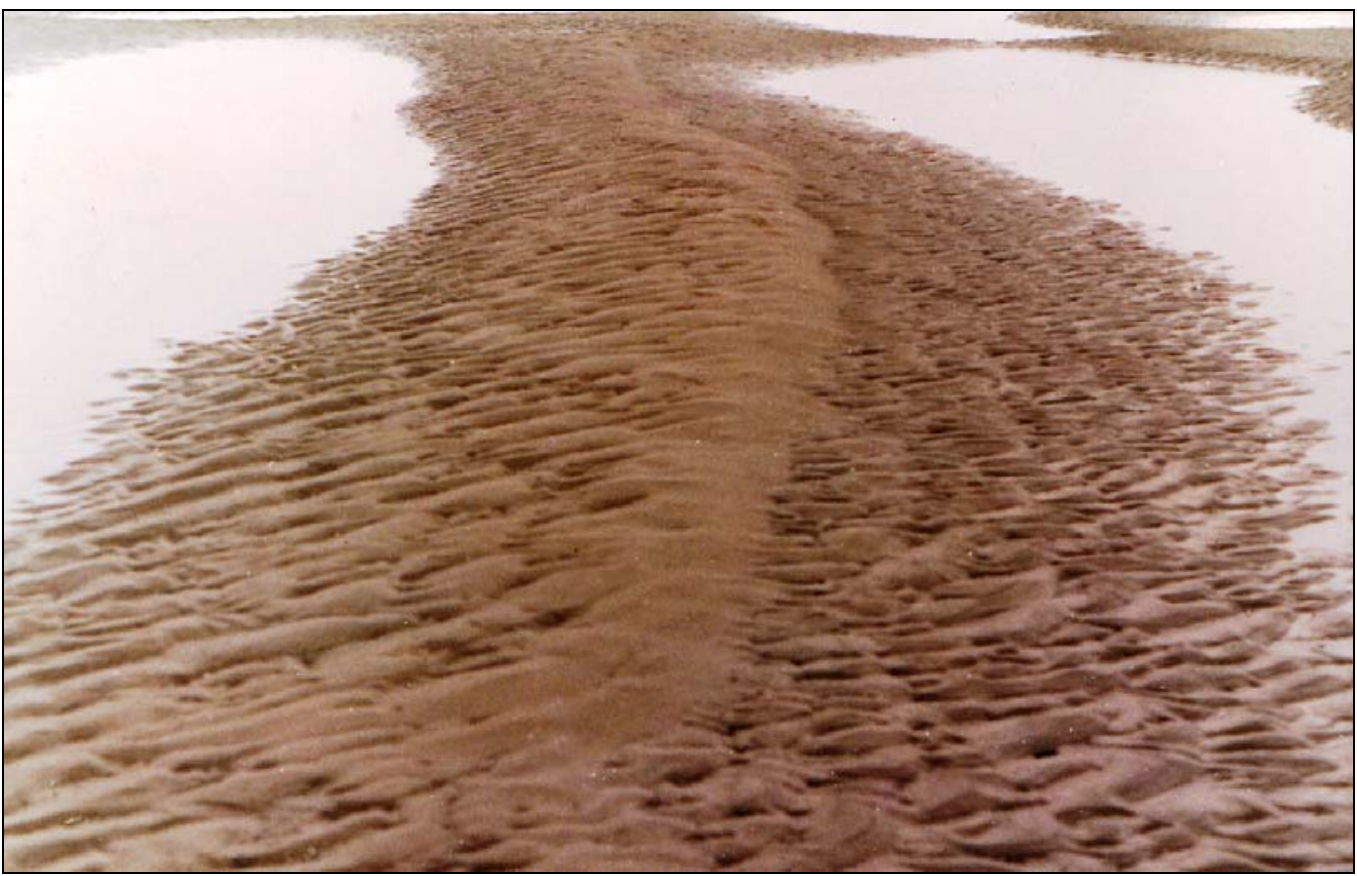

Fig. 5: Typical appearance of ebb-oriented, straight-crested megaripples (Type-I) with superimposed linguoid ripples on both stoss and lee slopes. 

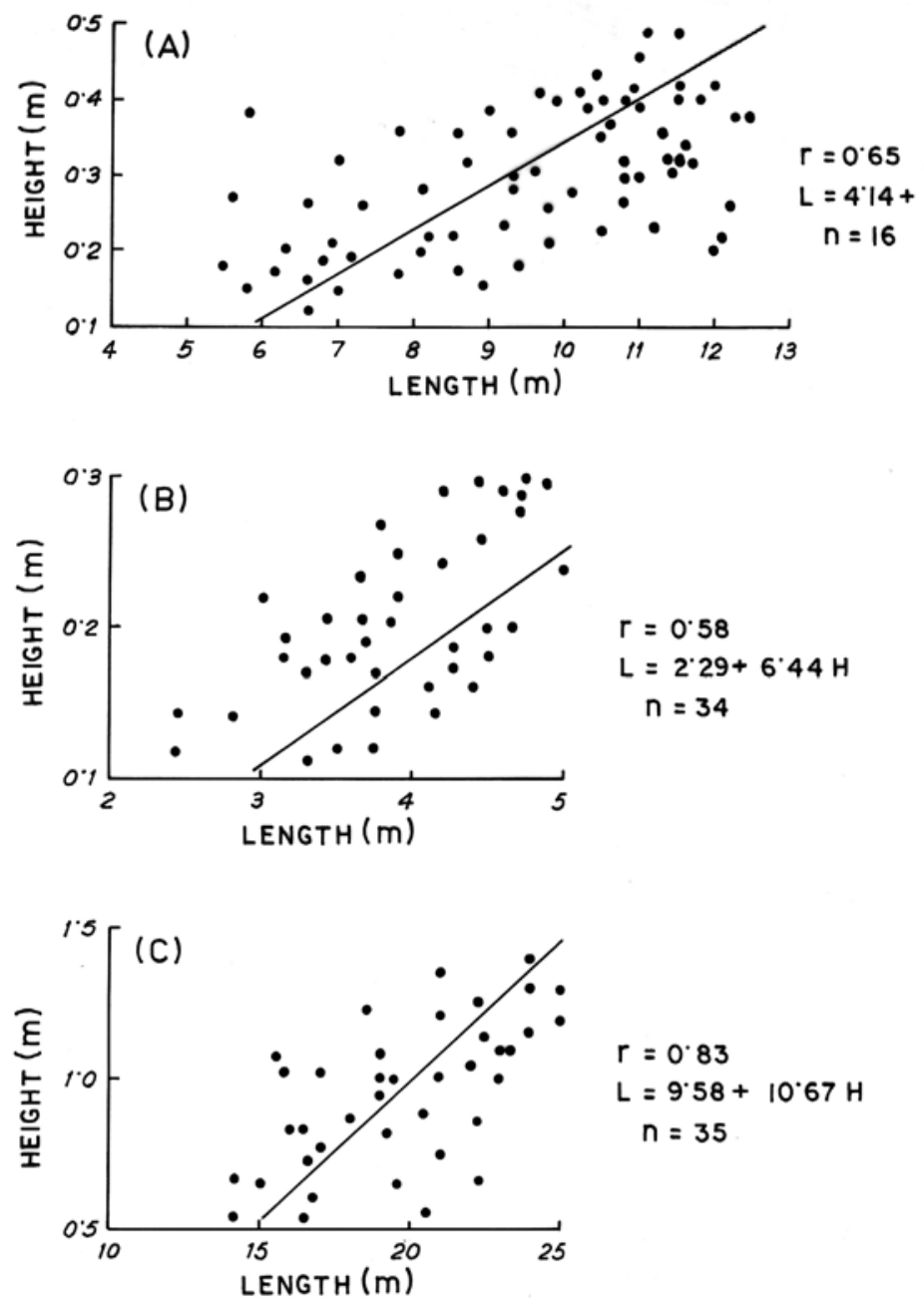

Fig. 6: Plot of Length versus Height of Straight-crested megaripples (A), Undulatory megaripples (B) and Sandwaves (C)

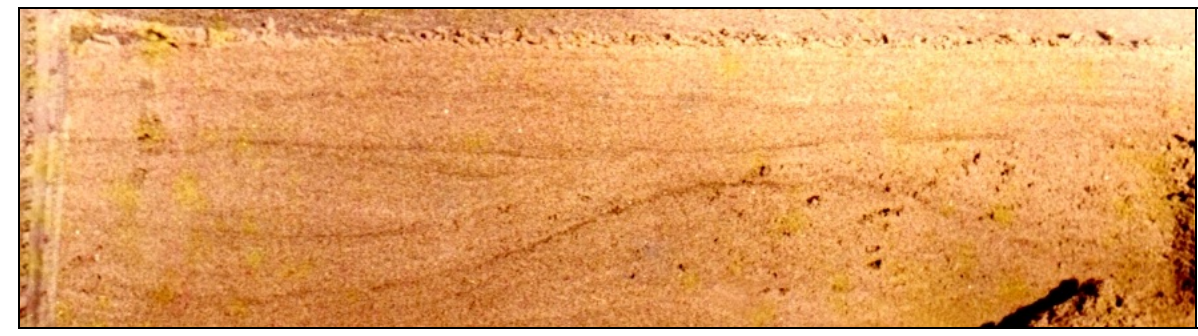

Fig. 7: Section parallel to river length through mid channel bar sand flat. The section shows a megaripple phase of sand deposits followed upward by horizontal and sub-horizontal bedding. 


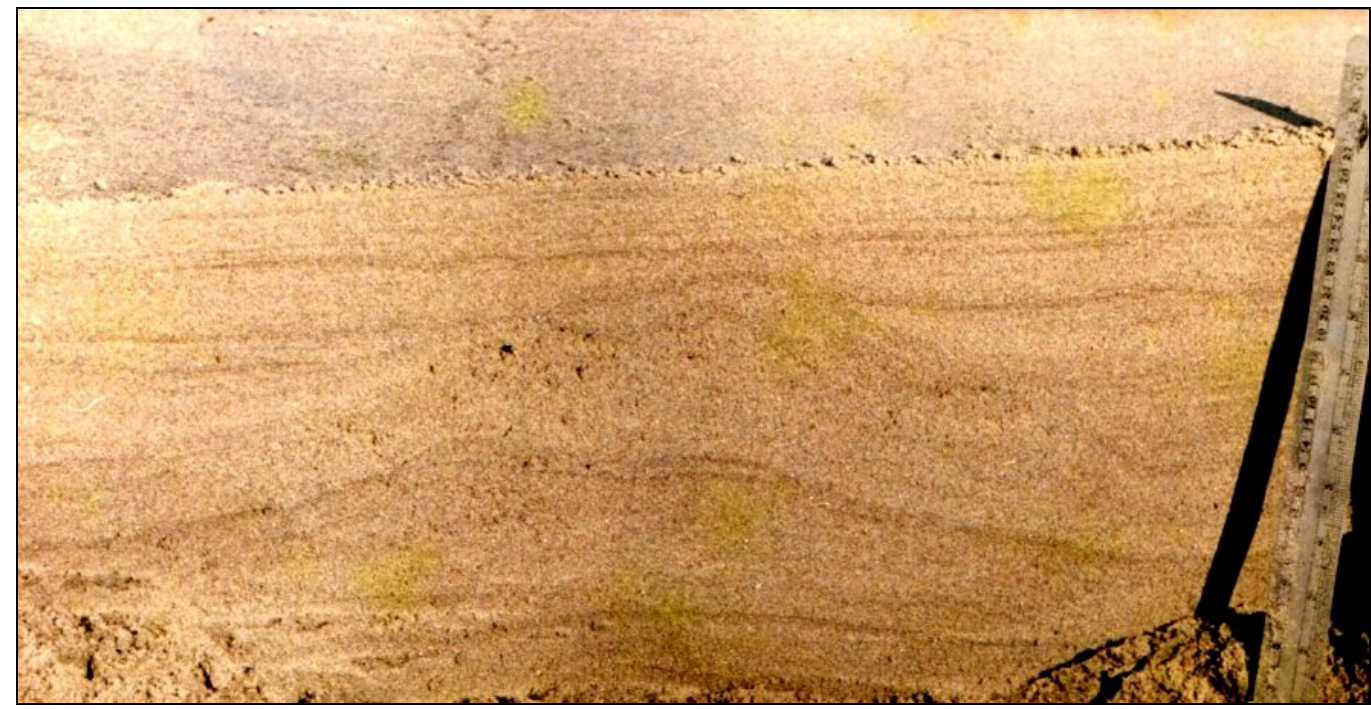

Fig. 8: Section parallel to river length through mid channel bar sand flat reveals megaripple phase followed upward by a plane bed sequence with a plane of truncation in between. The internal laminations of the megaripple phase show wavy undulation due to penecontemporaneous deformation. Megaripple crest with mud couplets and tidal bundles with sand-mud layers are also seen.

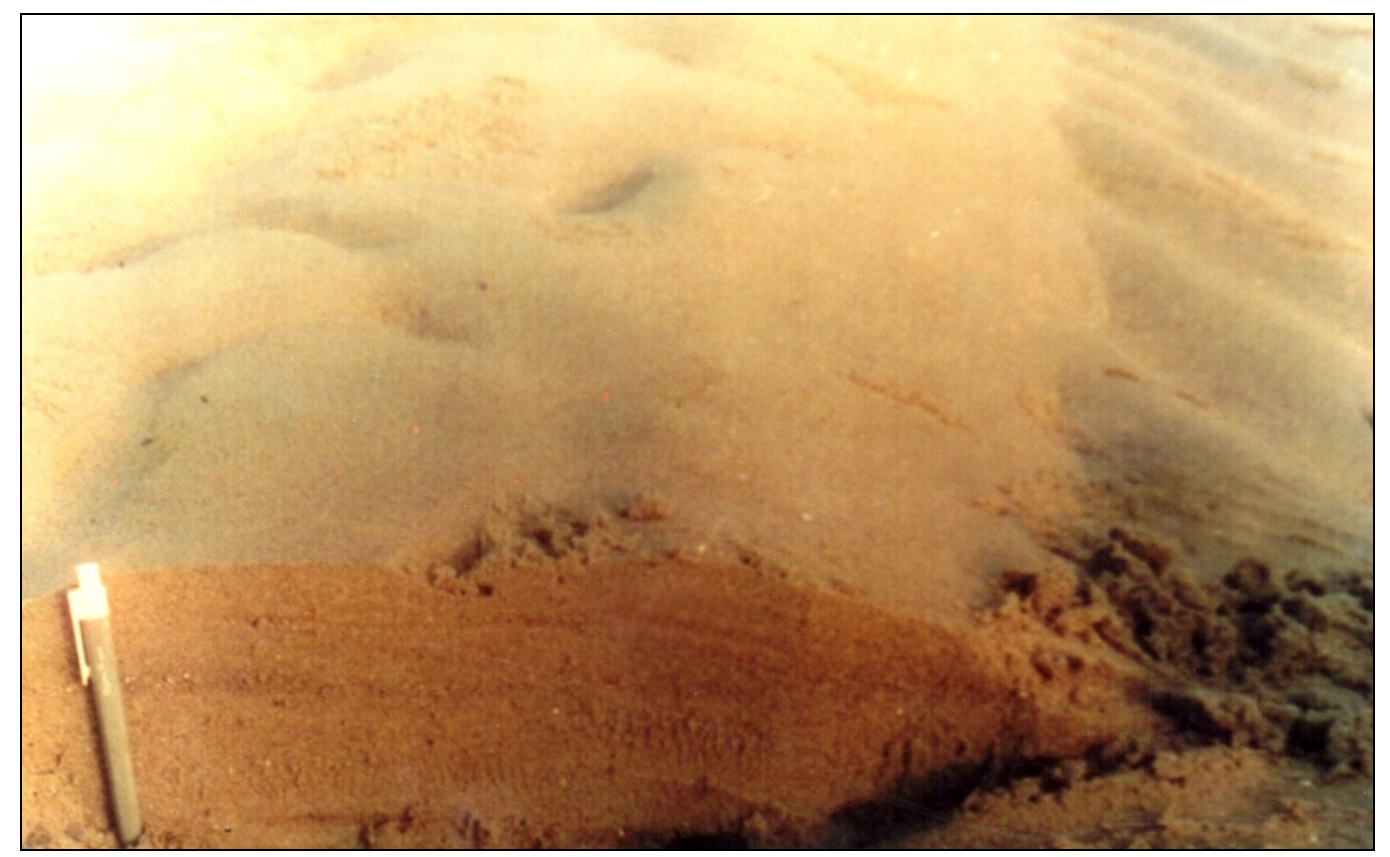

Fig. 9: Section through Paschim Sripatinagar mid channel bar revealing low angle cross stratification with convex upward reactivation surface. Pen is $15 \mathrm{~cm}$ 


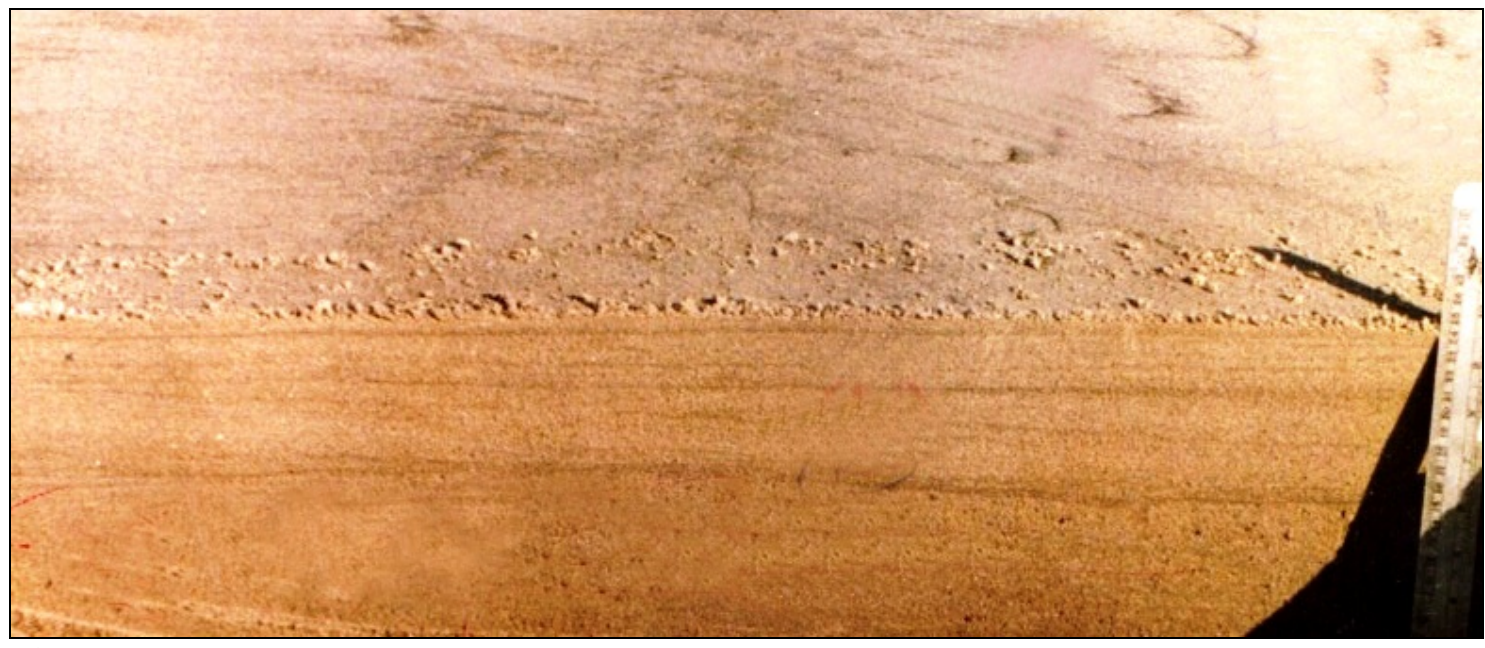

Fig.10: Section through Dhanchi mid channel bar showing tidal beddings with alternation of sand mud laminae. Note the deformed foresets in the lower unit. The surface shows current crescents. Rular is $30 \mathrm{~cm}$

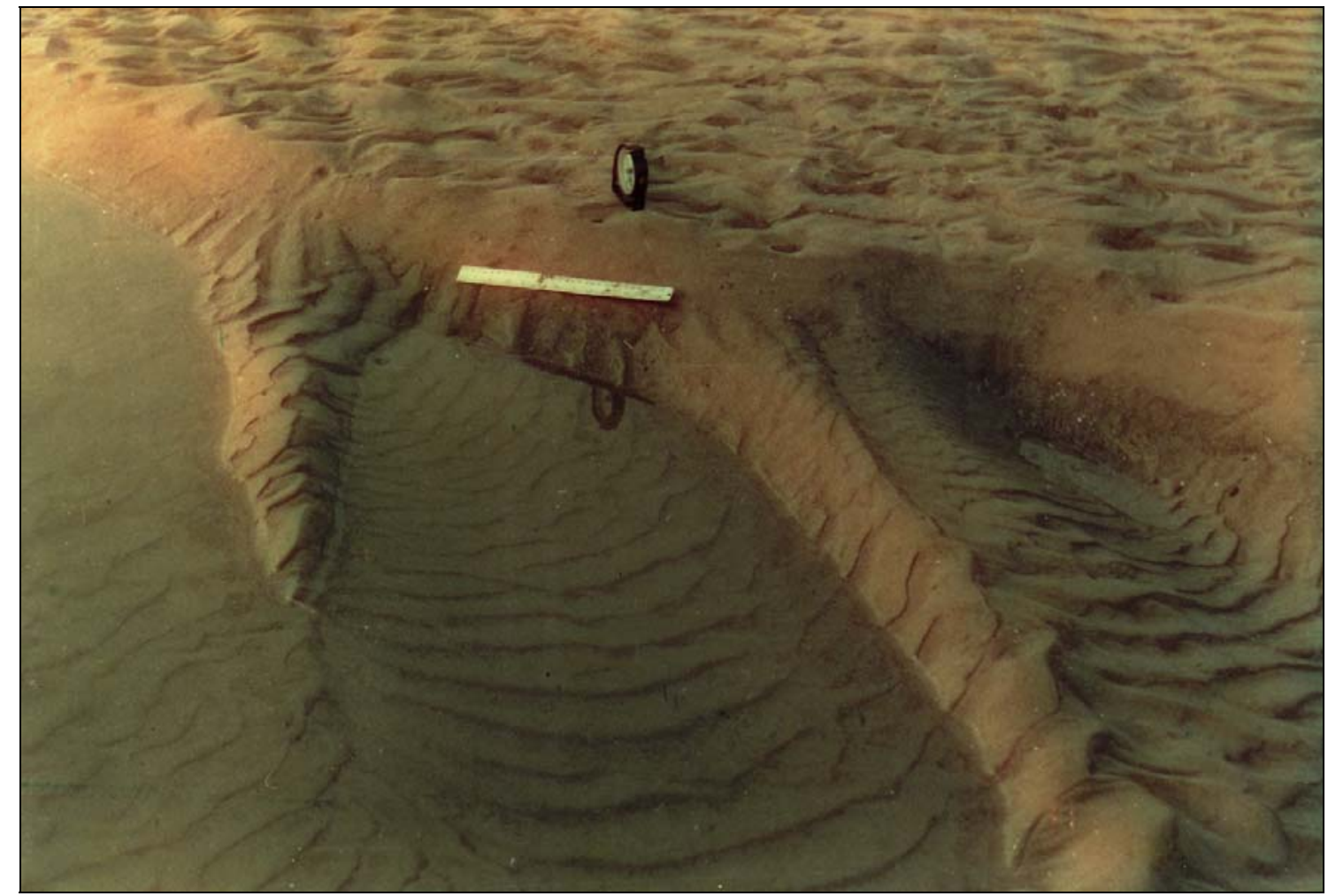

Fig. 11: Ebb-oriented straight-crested megaripples with sharp-crested spurs attached to the slip face at an angle of $45^{\circ}-80^{\circ}$ and mantled by ebb-oriented falling-stage ripplefans. The main current is from upper left to lower right. Scale is $30 \mathrm{~cm}$. 
The superimposed ripples are often eroded away from the crestal regions of megaripples because of flattening by tidal currents. In some cases the ripple trains are noticeable only along the flanks of megaripples. These conspicuous bedforms are supposed to form due to interference of tidal current-generated ripples with wave-generated ripples at the falling water stage with emergence of the mid channel bar.

The straight-crested megaripples correspond to Type-I megaripples described by Dalrymple et al. (1978) from the intertidal sand bodies in the macrotidal Bay of Fundy, Canada and by Elliott and Gardiner (1981) from the Loughour estuary, South Wales, UK. These megaripples, further, correspond to 'bar' phase of Costello (1974) and 'sandwave' phase of Middleton and Southard (1978). Many of the 'sandwaves' described from the macrotidal estuaries by Boothroyd and Hubbard (1975) and Boothroyd (1978) closely resemble the straight-crested megaripples of Reineck and Singh (1980) or type-I megaripples of Dalrymple et al. (1978).

\section{Undulatory Megaripples}

They possess long wavy or undulating crests and are devoid of well-developed scour pits in front of the slip face (Figs. 17 \& 18). In this respect they differ from lunate megaripples of Reineck and Singh (1980) or Type-II megaripples of Dalrymple et al. (1978) in which the crest line is broken and megaripples possess distinct scour pits in front. Both inphase and out of phase arrangement of undulations are present in a single megaripple train (Fig. 18). The crests show forward tongue-like projections and steep profiles in contrast to those of the straight-crested megaripples. The megaripple surface is ornamented by linguoid ripple and these ripples are produced during emergence. Allen's (1968) catenary megaripple corresponds to this type.

They form at higher velocities ( $>70 \mathrm{~cm} / \mathrm{sec}$ as specified by Reineck and Singh 1980) than that of the straight-crested type. The wavelength $(\mathrm{L})$ of the undulatory megaripples ranges from 2.43 to $4.88 \mathrm{~m}$, height $(\mathrm{H})$ from 0.14 to $0.32 \mathrm{~m}$ (Fig. 3C) and span from 7.3 to $11.58 \mathrm{~m}$ (Table-1). L/H ratio ranges from 9.48 to 29.16 and so less than that of straightcrested megaripples. A definite correlation also exists between length and height for these megaripples (Fig. 6B). Graphic mean size (Mz) of sediments constituting these megaripples ranges from 2.31 to 2.86 phi with mean of 2.42 phi. The undulatory megaripple is supposed to be an intermediate form between straight-crested megaripple of Reineck and Singh, (1980) or Type-I megaripple of Dalrymple et al. (1978) and lunate megaripple of Reineck and Singh (1980) or Type-II megaripple of Dalrymple et al. (1978).

\section{Sandwaves}

They are the largest scale bedforms observed on the mid channel bar. They are floodoriented two-dimensional forms and appear mostly on the floors of the flood-dominated portions of bar surface. They lack scour pits in their troughs and spurs on their slip faces. Ripples superimposed on sandwaves have been partially planed off by the preceding ebbflow. Their wavelength ranges from 15 to $25 \mathrm{~m}$, height from 0.65 to $1.4 \mathrm{~m}$ and span 43 to 97 m (Table-1). Their crests are straight to sinuous (Figs. 19, 20 \& 21). Crestal height remains constant along span. Plotting of wavelength versus height of sandwaves reveals a strong correlation (Fig. 6C). The length-height ratio ranges from 15.38 to 27.54. 
Open access e-Journal

Earth Science India, eISSN: $0974-8350$

Vol. 9 (II), April, 2016, pp. 53 - 103

http://www.earthscienceindia.info/

These sandwaves are similar to the "rippled sandwaves" (Dalrymple et al., 1975, 1978; Elliott and Gardiner, 1981) in terms of their scale of formation and superimposition by small-scale ripples. The relatively larger set of 'megarippled sandwaves' described by Dalrymple et al. $(1978,1990)$ is not found in the present study area. Despite a general similarity in the appearance of these ripples sandwaves with those of the Bay of Fundy and the Loughour estuary, they show marked differences in other attributes (Table-2).

Table-1: Bedforms of Thakuran and their dimensions.

\begin{tabular}{|l|l|l|l|l|}
\hline Bedform type & Length (m) & Height (m) & Span (m) & Steepness (L/H) \\
\hline \multicolumn{1}{|c|}{ A. Small-scale: } & $0.05-0.1$ & $0.005-0.009$ & $0.08-0.12$ & $10-24$ \\
\hline Ripples n=143 & $4.6-12.3$ & $0.15-0.43$ & $5.9-13.7$ & $14.8-57.14$ \\
\hline \multicolumn{1}{|c|}{ B. Intermediate-scale: } & & & \\
\hline $\begin{array}{l}\text { I. Straight-Crested } \\
\text { Megaripples } \\
\text { (=Megaripples Type-I of } \\
\begin{array}{l}\text { Dalrymple et al., 1978) } \\
\text { n=61 }\end{array}\end{array}$ & & $0.14-0.32$ & $7.3-11.58$ & $9.48-29.16$ \\
\hline $\begin{array}{l}\text { II. Undulatory Megaripples } \\
\text { (=Catenary and Sinuous } \\
\text { Megaripples of Allen, 1968) } \\
\text { n=34 }\end{array}$ & $2.43-4.88$ & & & \\
\hline \multicolumn{1}{|c|}{ C. Large-scale: } & $15-25$ & $0.65-1.4$ & $43-97$ & $15.38-27.54$ \\
\hline Sandwaves n=35 & & & \\
\hline
\end{tabular}

Table-2: Comparisons of the rippled sand waves of the present study area, Bay of Fundy and Loughour estuary.

\begin{tabular}{|l|l|l|l|}
\hline Parameters & $\begin{array}{l}\text { Bay of Fundy } \\
\text { (Dalrymple } \text { et al., 1978) }\end{array}$ & $\begin{array}{l}\text { Loughour Estuary } \\
\text { (Elliott \& Gardiner, 1981) }\end{array}$ & $\begin{array}{l}\text { Thakuran River } \\
\text { (Present Work) }\end{array}$ \\
\hline Orientation & Not stated & Majority Flood oriented. & Flood-oriented \\
\hline Lee-slope angle & $\begin{array}{l}\text { Much below angle of } \\
\text { respose, } 10-20^{\circ}\end{array}$ & $\begin{array}{l}\text { Steep angle of respose, 26- } \\
30^{\circ}\end{array}$ & $\begin{array}{l}\text { Steep angle of respose, } \\
25-28^{\circ} \text { (Comparable to } \\
\text { the megaripples lee } \\
\text { slope) }\end{array}$ \\
\hline $\begin{array}{l}\text { Nature of dominant } \\
\text { and subordinate tides }\end{array}$ & $\begin{array}{l}\text { Dominant and subordinate } \\
\text { tides not differentiated }\end{array}$ & $\begin{array}{l}\text { Dominant and subordinate } \\
\text { tides differentiated }\end{array}$ & $\begin{array}{l}\text { Dominant and } \\
\text { subordinate tides well- } \\
\text { differentiated }\end{array}$ \\
\hline Grain Size & $\begin{array}{l}\text { Coarser than medium sand } \\
\text { (Av. Mean size }=1.44 \text { phi) }\end{array}$ & Fine sand & $\begin{array}{l}\text { Medium to fine sand } \\
\text { (Av. Mean size }=2.66 \\
\text { phi) }\end{array}$ \\
\hline Stability & $\begin{array}{l}\text { Do not form stable } \\
\text { bedform field; shows } \\
\text { disequilibrium and } \\
\text { decaying form of } \\
\text { megarippled sandwaves }\end{array}$ & $\begin{array}{l}\text { Stable bedform field; } \\
\text { without showing } \\
\text { progradation or retrogration } \\
\text { to another bedform type }\end{array}$ & $\begin{array}{l}\text { Stable bedform field; do } \\
\text { not prograde or } \\
\text { retrograde to other } \\
\text { bedform type }\end{array}$ \\
\hline Tidal amplitude $>16$ m & $\begin{array}{l}\text { Semidiurnal } \\
\text { Tide }>7 \text { m } \\
\text { mean neap: } 4.0 \mathrm{~m} \\
\text { mean Spring: } 8.1 \mathrm{~m}\end{array}$ & $\begin{array}{l}\text { Semidiurnal } \\
\text { Tide }>4.5 \mathrm{~m} \\
\text { mean neap: } 3.0 \mathrm{~m} \\
\text { mean Spring: } 5.5 \mathrm{~m}\end{array}$ \\
\hline
\end{tabular}




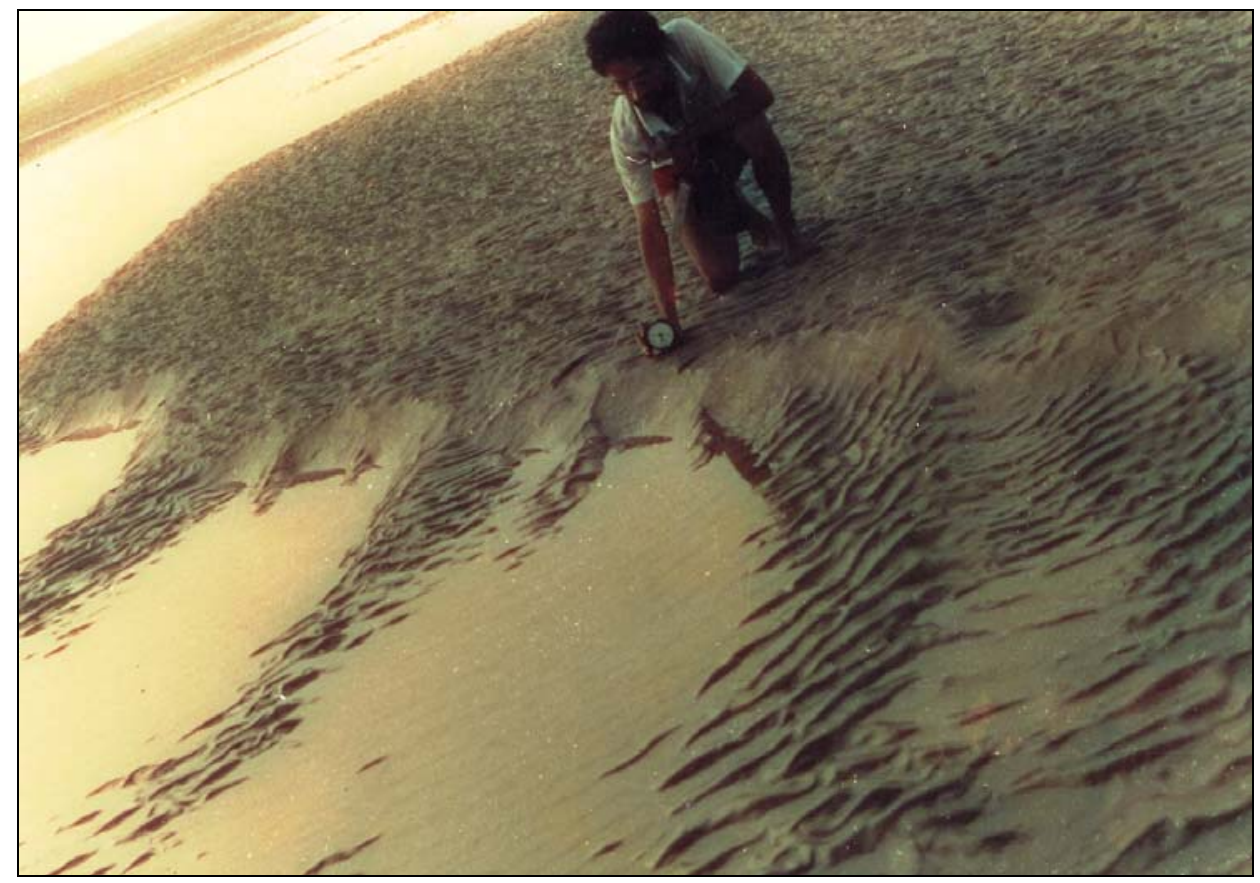

Fig.12: Ebb-oriented straight-crested megaripples in decaying stage. Slip face of megaripples not clearly discernable in places. Note the continuation of the crests of small ripples from megaripple surface to the crests of spurs up to underwater ripples. Ripple fanning is not prominent in front of slip face.

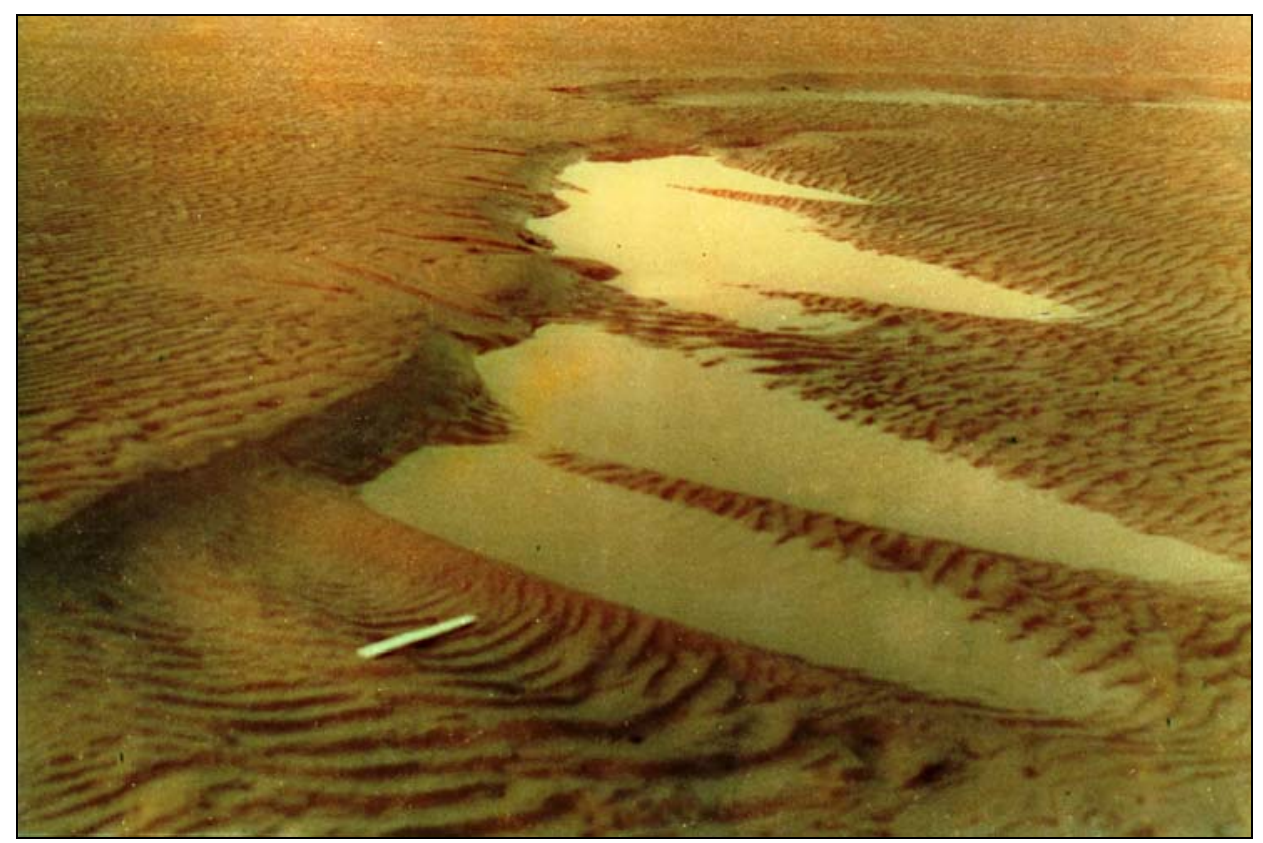

Fig. 13: Ripple troughs are partly filled with water. Water level marks are seen on the slip face of the straight-crested megaripples. The superimposed small ripples were formed after megaripples ceased to migrate. Note the change of ripplefans into linguoid ripples. Scale is $30 \mathrm{~cm}$. 


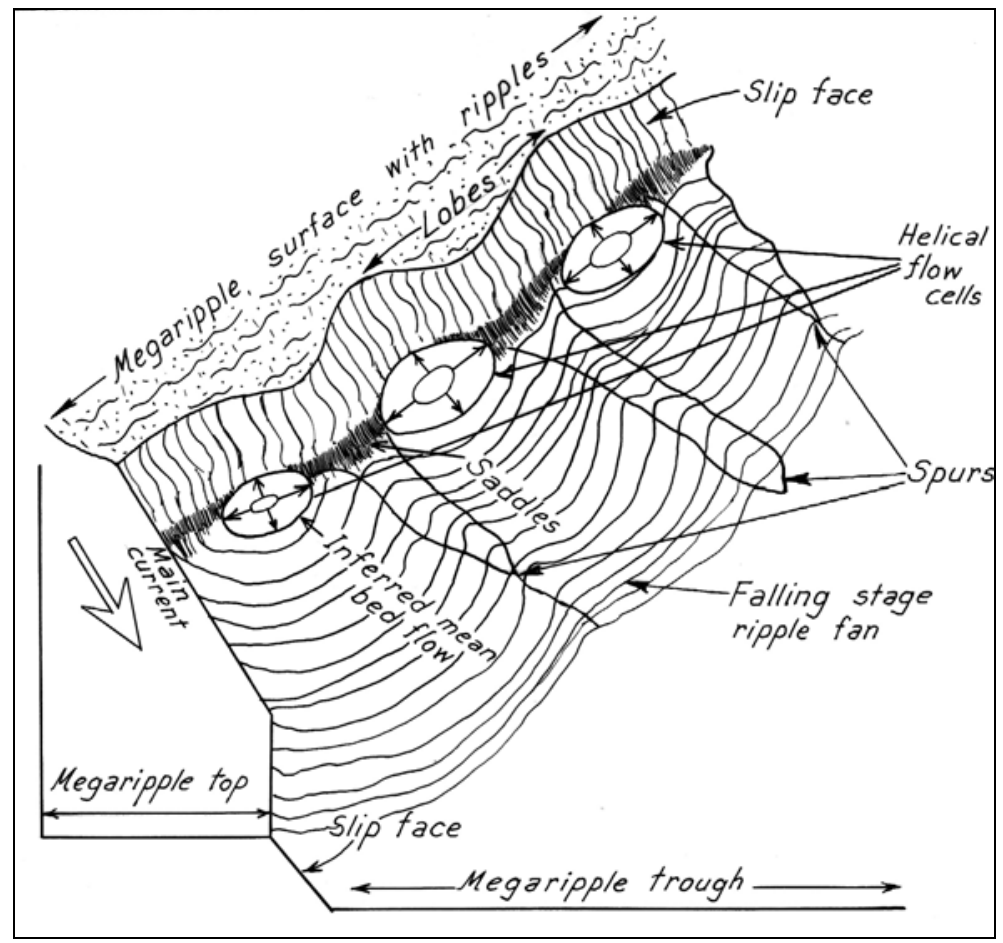

Fig.14: Ripple fan development in the separated flows to lee (slip face) of straight-crested megaripples (modified after Allen, 1984).

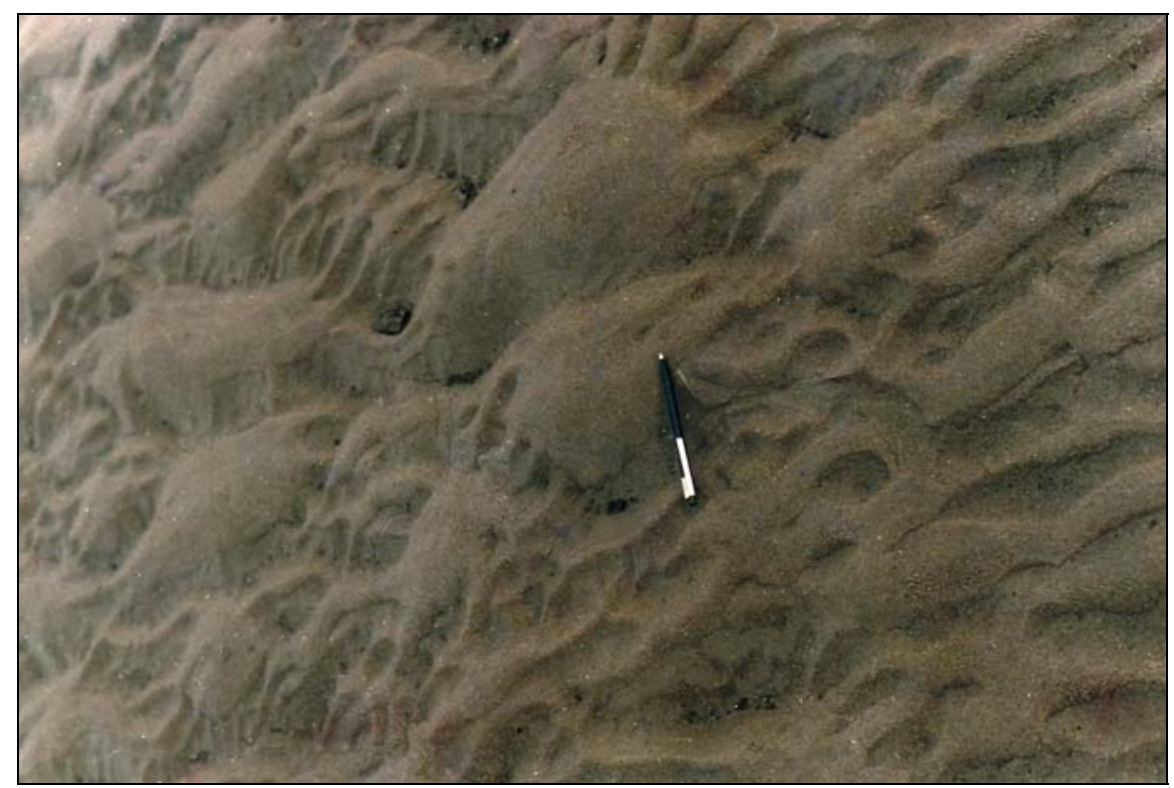

Fig. 15: Small-scale wave ripples climb over the megaripples and interfere with the crestal trains of megaripples. Flattening of crests of megaripples often obliterate the superimposed ripples. Pen is $15 \mathrm{~cm}$. 


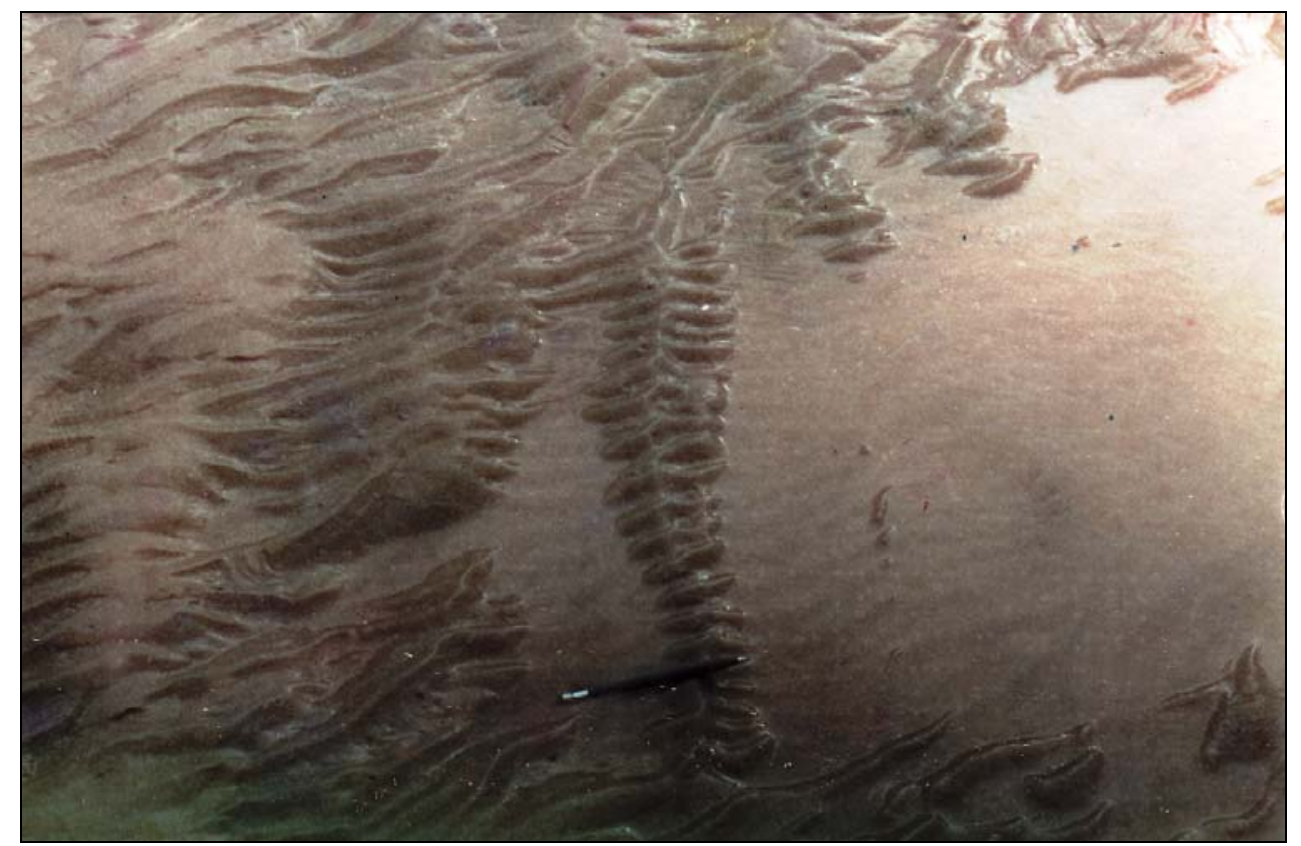

Fig. 16: Climbing-up of small scale ripples over the medium-scale asymmetric ripples. Crestal trends of two sets of ripples are at oblique angles. Fanning of ripples across medium-scale ripple crests is seen during period of bar emergence.

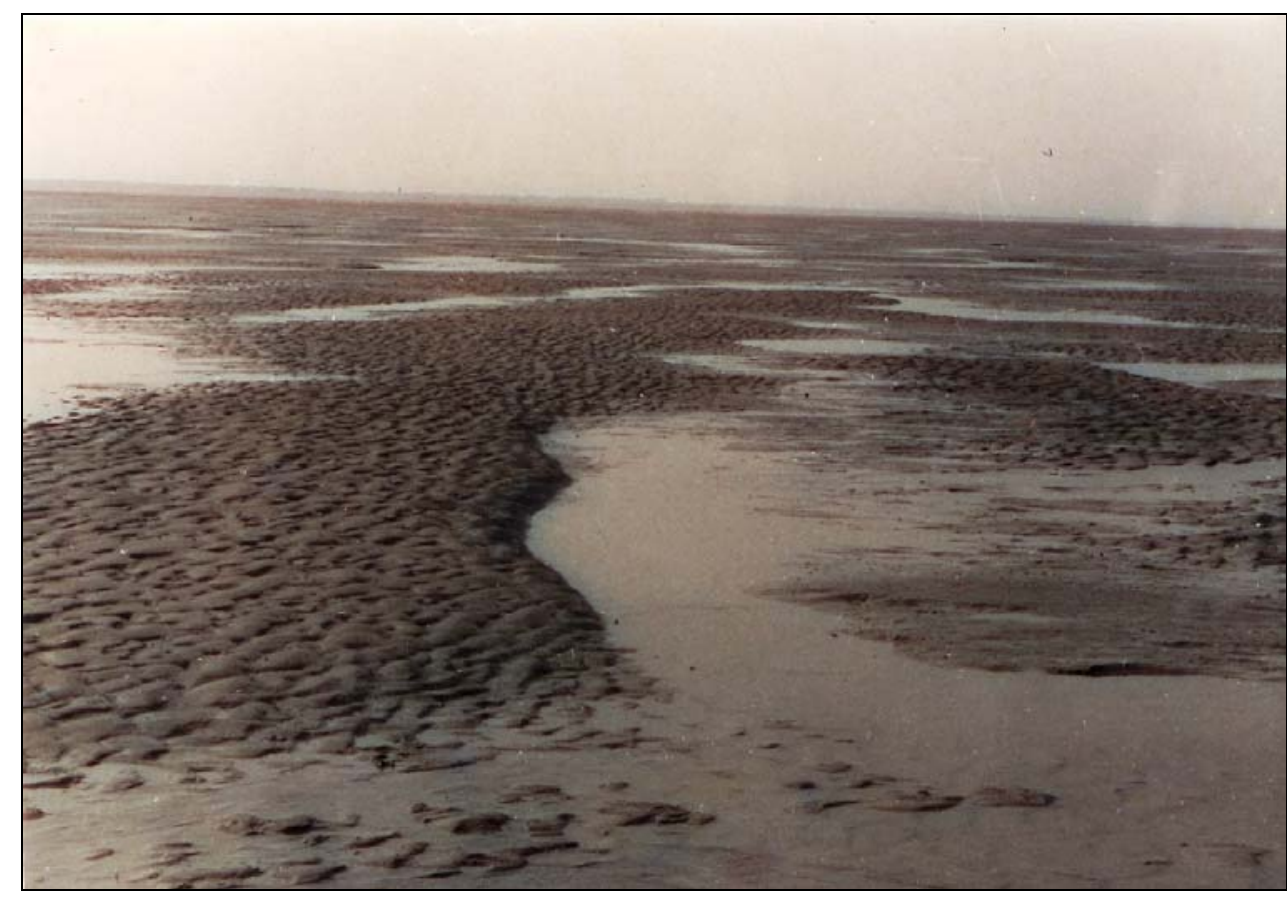

Fig. 17: Undulatory megaripples with continuous wavy crests projected forward into tonguelike extension. Ripples are superimposed on megaripple. Megaripple spacing is about $2 \mathrm{~m}$. 


\section{Internal Physical Structures of the Mid Channel Bars}

With a purpose to examine the internal manifestations of the bedforms generated on the mid channel bars several L-shaped trenches were dug during the time of emergence. Barring a few mid channel bars (e.g. that of Paschim Sripatinagar, Dhanchi), many of the mid channel shoals undergo complete submergence during both flood and ebb-tides. As a result, there was limited opportunity for examining the trench sections. However, the following types of internal structures were identified and examined in details.

\section{Megaripple Bedding}

The upper surface of this type of bedding is undulatory, non-erosional surface of the megaripples preserved as foreset (Fig. 7). The megaripple form is capped by a thin veneer of mud of a few mm-thicknesses. The megaripples in section are $50-60 \mathrm{~cm}$ long, 12 to $18 \mathrm{~cm}$ high and correspond well with that of the surface megaripples.

This bedding type is the internal manifestation of megaripples that migrate with flood currents. The thin mud veneer at the crests and troughs of megaripples presumably indicates deposition of mud during periods of slackening of tidal currents. The angle of repose of lee slopes of surficial megaripples corresponds well to the angle of inclination of the foreset laminae of subsurface cross-bedded units.

\section{Parallel Stratification}

The megaripple bedding in most cases is followed upward by parallel stratification (Harms and Fahenstock, 1965) with distinct tidal bundles characterized by alternations of fine sand-mud couplets (Figure 8). The thickness of individual layer ranges in mm-scale being confined within cm-scale sets of parallel stratification.

Parallel stratifications have non-erosional contact with the underlying unit. The fine sand and mud are quite obviously deposited from suspension by slowly moving tidal currents. The intercalated mud stringers within fine sandy laminations also imply deposition from tidal slackening during ebb tide.

\section{Horizontal stratification}

Trench sections on sand flat surface of mid channel bars exhibit sets of horizontal stratifications as internal structure. The laminae within the sets of horizontal stratifications are often ill-defined or faintly marked (Fig. 10). Some laminae become quite prominent due to concentration of heavy minerals. The sets of horizontal stratifications range from less than a $\mathrm{cm}$ to a few $\mathrm{cm}$. The lower bounding surface of each set is erosional, horizontal to subhorizontal and planar. The horizontal stratifications are essentially made up of sand size particles and in this respect they differ from parallel stratifications, which are made up of finer sized particles and essentially maintain a non-erosional contact with the underlying unit.

Horizontal stratification is the internal manifestation of plane bed or featureless surface of sand transport (Harms and Fahenstock, 1965). Such surfaces generally occupy relatively more elevated areas of mid channel bars where sand moves in a streaming fashion without any turbulence. 


\section{Reactivation surfaces in cross-bedded units}

In some occasions, convex-upward reactivation surfaces are present within crossbedded units (Fig. 8). Mud drapes are absent in the cross-bedded units (Houthuys and Gullentops, 1988). Reactivation surfaces indicate pause planes (Boersma and Terwindt, 1981) within the cross-bedded units and appear as discontinuities in pattern and attitude of foreset laminae. Fluctuations or changes in flow mechanism or direction in tidal currents is responsible for the generation of such discontinuity or pause planes.

\section{Penecontemporaneous deformation of soft-sediments}

These structures include some disturbed, distorted or deformed sedimentary layers (Figs. $9 \& 10$ ) in the mid-channel bar deposits. The deformations occur simultaneous with or shortly after the deposition of sediments. The deformed laminae remain confined to a single unit within a sequence of undeformed units.

Somewhere, the deformations are marked by slightly disturbed layers with minor undulations or folding (Fig. 9). The deformed layers (2-3 cm thick) are confined within absolutely undeformed horizontal stratifications. The deformations broad warp of laminae at a depth of 3-4 cm from the mid-channel bar surface.

Deformations noticed in other trench sections are much more complicated showing convolutions of laminae within undeformed overlying and underlying units (Fig. 10). The deformations are confined within 3-4 cm thick unit. Very fine alternations of sand and mud laminae reflect a tidal-bedding origin of the deposits.

Both varieties of deformation in the present situation point to their origin from plastic flow of materials resultant from unequal shear as explained by Mckee et al. (1962a).

\section{Modification Features Resultant from Unsteady Flow in Tidal Environment}

Tidal processes are characterized by many scales of unsteadiness in usual natural settings. Of many such causes of unsteady flow the following seem to be the most important.

(i) Fluctuating velocity and depth within ebb and flood periods

(ii) Flow reversals associated with successive ebb and flood periods

(iii) Contrasts in neap and spring tidal flow

(iv) Seasonal variation in tides between equinox and solstice i.e. with equinoctial cycles

Although bedforms are generally considered to be the result of principal flow and related sediment transport conditions, several effects of unsteadiness in flow are not commonly emphasized. But individual bedforms and the overall bedform assemblages at a point of time do reveal features due to one or more of the above mentioned scales of unsteadiness. The present section deals with a wide range of modification bedforms in the Thakuran River bed that are associated with (i) to (iii) of the above mentioned scales of unsteadiness. The author however, could not detect any feature in response to equinoctial cycle. 
Open access e-Journal

Earth Science India, eISSN: $0974-8350$

Vol. 9 (II), April, 2016, pp. 53 - 103

http://www.earthscienceindia.info/

\section{Modification bedforms resultant from fluctuating velocities and depths with ebb and flood periods}

For large-scale bedforms like megaripples and sand waves, modification takes place when the flow velocity falls during waning phase of ebb or flood currents from peak flow conditions. This velocity is unable to migrate the slip faces of these large-scale features. Waning of flood periods involve a progressive reduction in flow velocity accompanied by an increase in flow depths. On the contrary, during waning ebb periods, decrease in flow velocities is accompanied by decrease in flow depths. As a consequence, the intertidal mid channel bar surface undergoes a brief period of high flow velocities with shallowing depth immediately prior to emergence. These changes in flow conditions are referred to as "falling stage" (Elliott and Gardiner, 1981) and during this state of change of ebb periods the following modification features have been noticed. Observations of these features on the bar surface can only be made for a short period after the ebb flows.

\section{i) Skewed Spurs}

These features appear under direct observations and measurements for a short span of time limited within low water periods after recession of tides. Some of the straight-crested megaripples are unique by possessing sharp-crested skewed spurs, which project downcurrent from the slipface at an angle of $60-90^{\circ}$ (Figs. 11, $12 \& 13$ ). The slipface is planar or curved. The portion of the lee slope which projects down-current is called the "saddles", whereas, the re-entrant sections form the "lobes" (Fig. 14). The spurs in the present study area are generally attached to the saddles of the slipface (Figs. $13 \& 14$ ).

The spacing between two successive spurs ranges from 0.85 to $1 \mathrm{~m}$ and the spurs continue for 1-3 m down-current before dying out (Figs. 11, 12 \& 13). The elongated scour pits that occur in between the spurs contain ripple fans, which run continuously across the spurs. The ripple trains surmount the crests of the spurs in almost all cases. The ripplefans, however, are not always associated with spurs and grooves. Such features known as "ripple scours” (Figs. 11 \& 13) have been described by Potter and Pettijohn (1963) and Allen (1984). Straight-crested megaripples with skewed spurs are more or less permanent features of mid channel bar surface although they shift their position with time.

Spurs attached to have been described by Allen (1968), Knight (1972), Dalrymple et al. (1978) and Elliott and Gardiner (1981). In Allen's experiment these scours and spurs were developed by pairs of contra-rotating vortices with helical-spiral motion. Knight (1972) described the skewed vortices to be the product of a change in flow direction during falling stage of ebb-flow. Elliott and Gardiner (1981) supported the interpretation of Knight (1972). The present worker, in accordance with the interpretation of Elliott and Gardiner (1981) holds that with the fall of water-level from the earlier deeper flows, the flow direction changes with increase in local slope in front of the slipface. Vortices developed in front of the slipface produce evenly-spaced swept areas and spurs. With further fall of water level the ripplefans superimpose the spurs and grooves (Fig. 14). 
Open access e-Journal

Earth Science India, eISSN: $0974-8350$

Vol. 9 (II), April, 2016, pp. 53 - 103

http://www.earthscienceindia.info/

\section{ii) Ripplefans}

The ripplefans (Allen, 1968) are mostly superimposed on the stoss slope of sandwaves and on the troughs of the straight-crested megaripples (Figs. 11, 12 \& 13). However, their occurrence along the troughs of straight-crested megaripples is by far the most common. They have an overall fan shape with the ornamentation of an ordered pattern of asymmetrical ripples. Their continuous crestlines fan away from the slip face of megaripples (Figs. 11, 12 \& 13). Wavelength of this ripplefans break down and change into linguoid ripples as they ascend the stoss slopes of the next succeeding megaripples (Fig. 13).

In the present field of study the ripplefans develop at the falling stage conditions when a number of helical flow cells generate in front of the slip face (Fig. 14). These "cells" are divided transversely along imaginary stream lines called "seams" (spurs) towards which the ripples have a component of facing (Figs. 11, 12 \& 13). The seams usually coincide with the crest of spurs (Allen, 1984). This is substantiated by the fact that the point of origin of the ripplefan is located close to the foot of the slip face. This suggests that the separation of eddy has effectively contracted with distance. Further, the skewed nature of the ripplefans downslope points to increasing influence of the slope as the water level falls (Elliott and Gardiner, 1981).

\section{iii) Planned-off Crest of Megaripples and Sandwaves}

At places the megaripples and sandwaves are planed off removing the superimposed ripples; the bedform crests become wider (Figs. 20 \& 21). The superimposed ripples may be retained only in isolated patches on the generally planed off surface. These surfaces originate just before the bedform emergence when the plane bed flow regime prevails only for a short while.

The superimposed ripples formed earlier are largely obliterated due to swift erosion of the large-scale bedform crests. These modulations are obvious responses of bedforms to changing flow velocity and depth within flood-ebb periodicity. Boothroyd and Hubbard (1975), Dalrymple et al. (1978; 1990), Elliott and Gardiner (1981) described these structures from intertidal sand bodies under meso- and macrotidal settings. Boothroyd and Hubbard (1975) considered them to constitute a separate class of bedforms having a specific position in a flow-regime scheme rather than results of modification of pre-existing bedforms as suggested by Dalrymple et al. (1978).

\section{iv) Dissection Channels and Microdelta}

The spurs attached to the slip face of straight-crested megaripples are occasionally cut by narrow steep sided channels transverse to the spurs. Sediments eroded by these channels are deposited at the mouth of the channels as a microdelta which progrades towards the troughs of the megaripples (Fig. 22). In plan, the microdelta is typically triangular with a lobate front. The surface of the microdelta is often characterized by linguoid ripples developed during late-stage run off.

\section{v) Strandlines}

Slip faces of megaripples and sandwaves are very commonly etched or marked by closely spaced parallel lines which reflect slight reworking of slipface by successively lower water level (Klein, 1970; Reineck and Singh, 1972). With falling water, at different levels a series 
of such markings are formed. They indicate sinking water levels in an area exposed to intermittent subaerial exposure.

\section{Modification Bedforms due to flow reversals}

The flood-oriented megaripples and sandwaves on the mid channel bars are exposed in many areas following the ebb tide. Observations in the field reveal that the crests of these large-scale structures are occasionally rounded and their upper surface supports small asymmetrical ebb-oriented ripples. The subordinate ebb tide has limited reworking ability to wholesale change the orientation of the large-scale structures. The ebb-oriented ripples also occur locally as low-angle mounds. Heights of these ripples range from 2 to $8 \mathrm{~cm}$, whereas, their slip faces range from $12^{0}$ to $20^{0}$.

\section{Modification bedforms due to contrasts between neap and spring conditions}

The megaripple fields in the study area generally shift their positions in response to contrasted neap-spring cycles. Zones of decaying megaripples appear as the most conspicuous feature formed under condition.

\section{i) Decaying Megaripples}

Megaripples often retain their orientations during neap-spring cycles. They maintain their prominence both in conditions of waxing and waning of neap-spring cycles. Under favourable conditions, the undulatory megaripples and megaripples of Type-I increase in wave length, diminish in height and therefore become less distinct and less prominent (Elliott and Gardiner, 1981). Occasionally, sediment transport along the ripple fields enhances decaying of megaripples. Thus, megaripples of low height are produced by transformation and these megaripples are often superimposed by linguoid ripples (Das, 2016). The slip faces are generally weakly discerned or may be absent in extreme cases.

\section{Ripples}

\section{Description of Small Scale Bedforms}

Ripples are the smallest bedforms on sand flats. There are many kinds of ripples of which the complex interfering type is quite abundant. Each type of ripple has its own separate field covering large areas particularly, on the topographically higher levels of mid channel bars. On the contrary, in topographically lower areas different kinds of ripples occur in close association with one another.

Generally the ebb-oriented and flood-oriented ripples are asymmetrical, linguoid form. They occur in exclusive fields of their own. Both symmetrical and asymmetrical straight-crested ripples of short wave length are found locally in areas of wind-driven waves active in shallow water. Areas of interference of waves and currents produce interference ripples of much complex morphology. Ripples of more than one type occur in close association where the hydrodynamic conditions change within small areas. The various kinds of ripples are described below. 


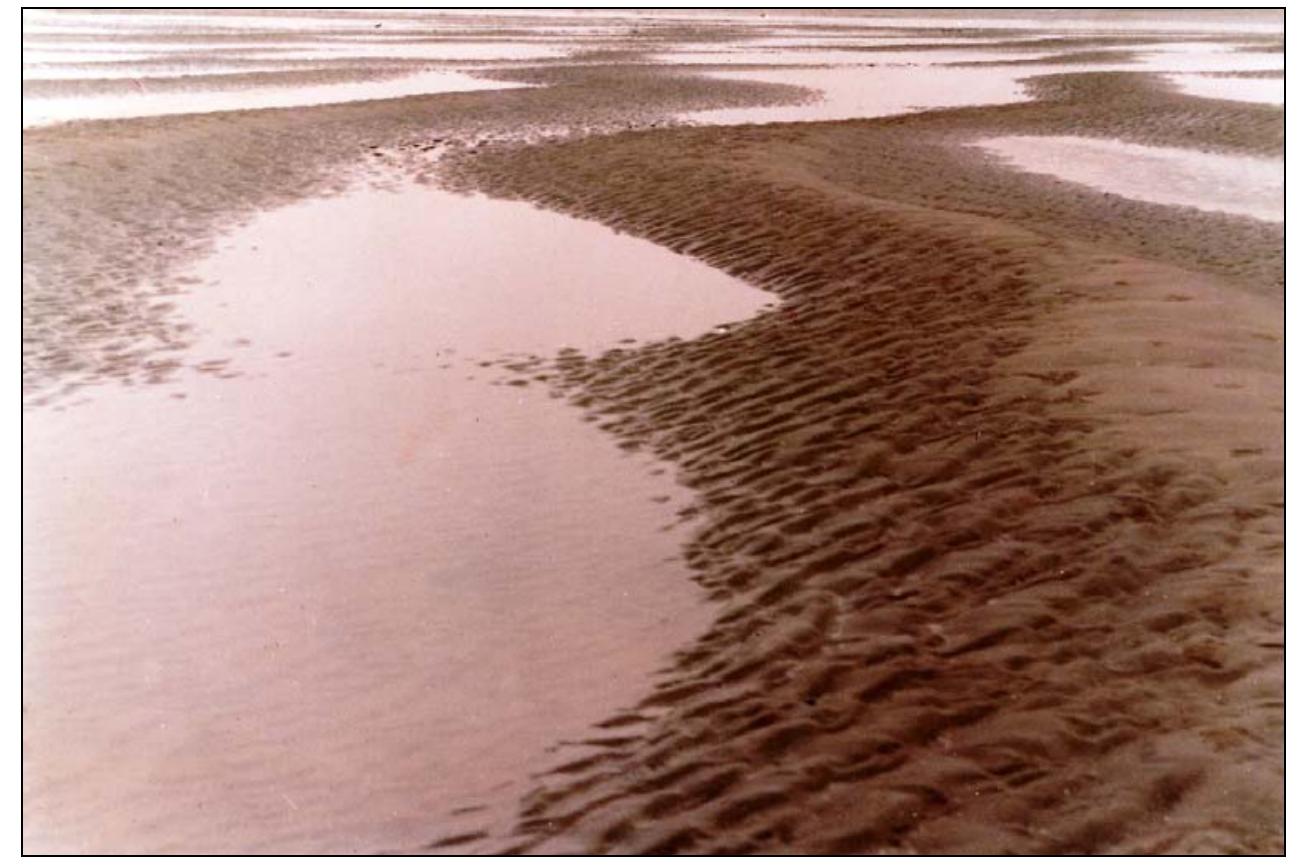

Fig. 18: Undulatory megaripples with in-phase and out of phase arrangements of the undulations.

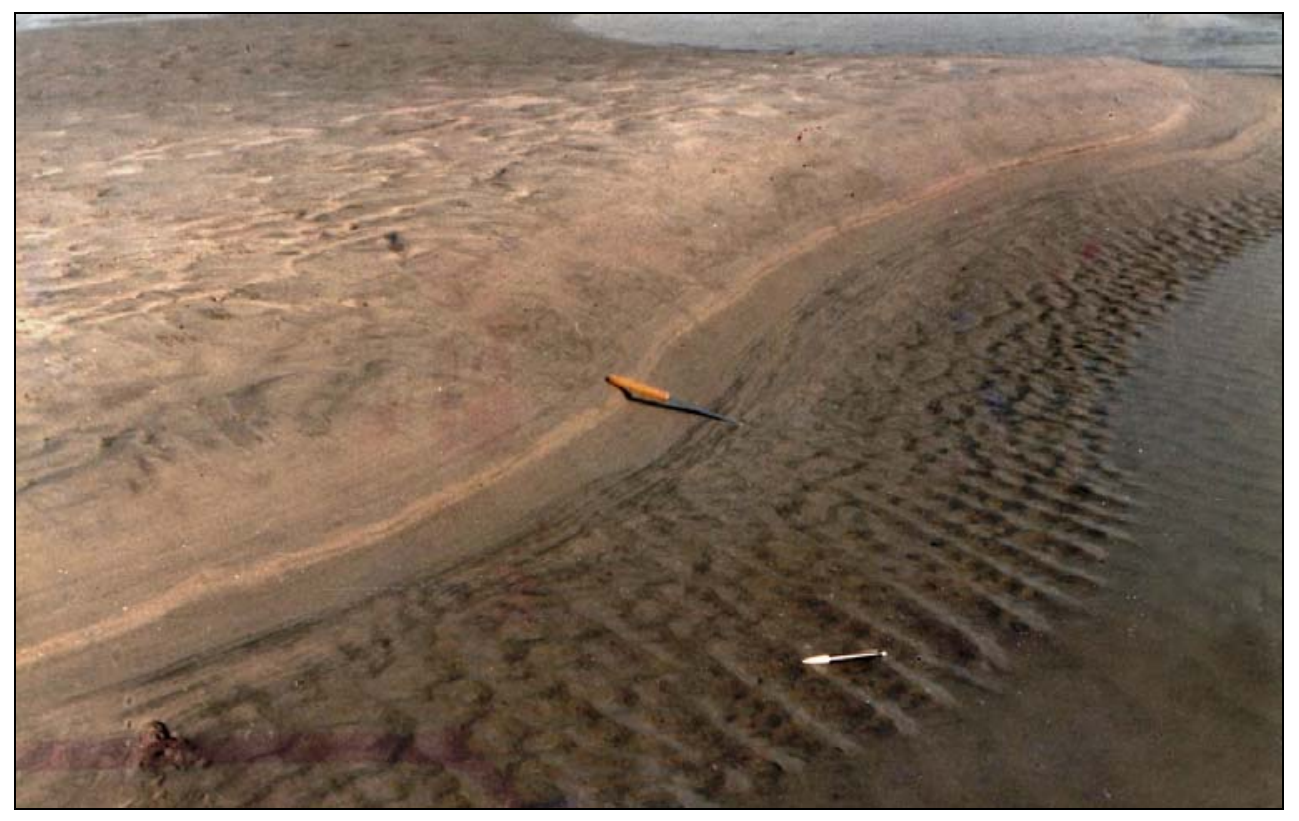

Fig. 19: Small-scale, ebb-oriented ripple aprons on the crest of a flood-oriented sandwave. Note also the channel system extending along the trough line of the sandwave. Superimposed ripples show fanning on the lee face of the sandwaves. 


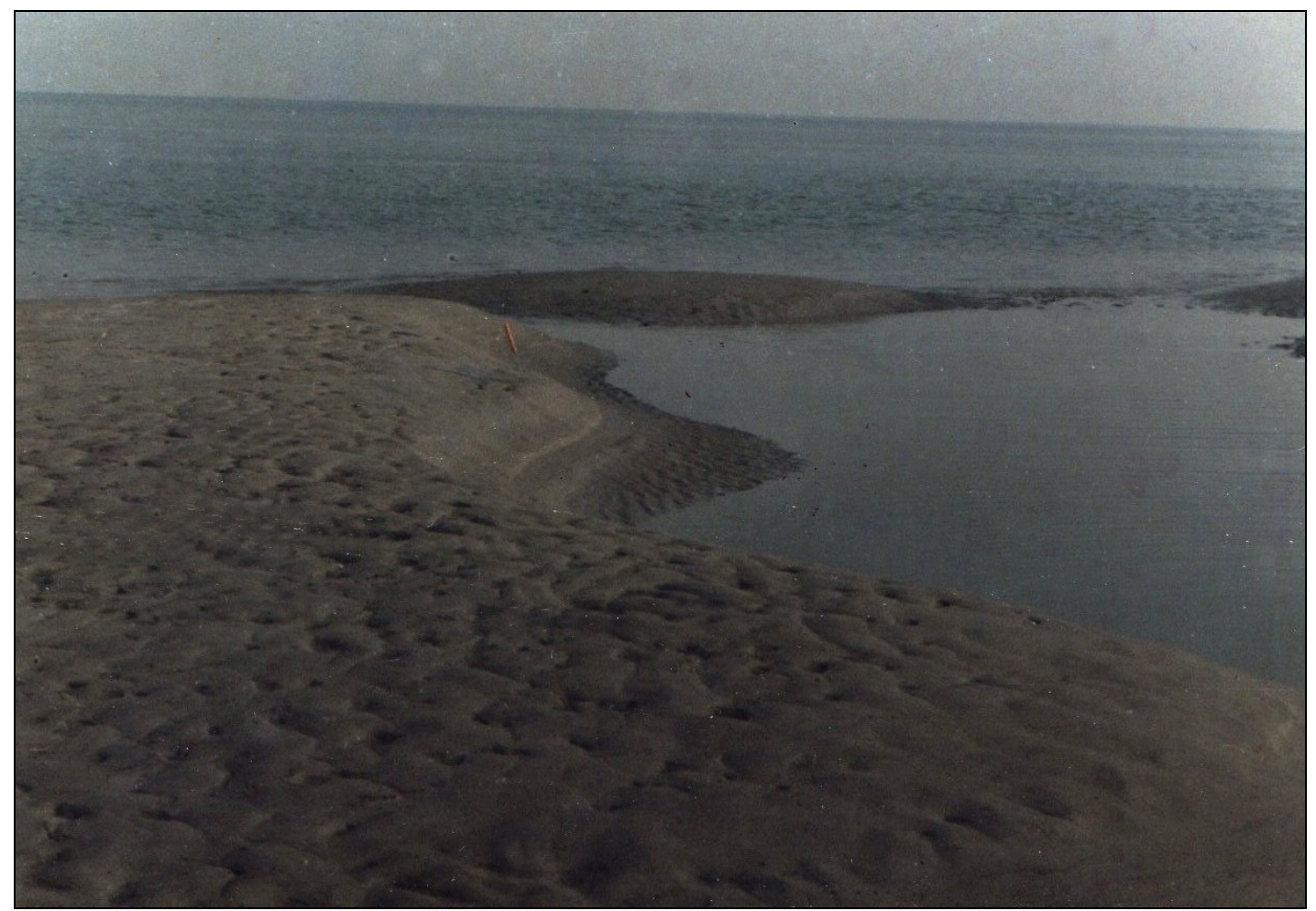

Fig. 20: Flood-oriented sandwaves with a simple two-dimensional form and lack of scour pit. The superimposed ripples are partially planed-off by the proceeding ebb flow. The foreground is an ebb-apron formed from reworking of the bedform crest.

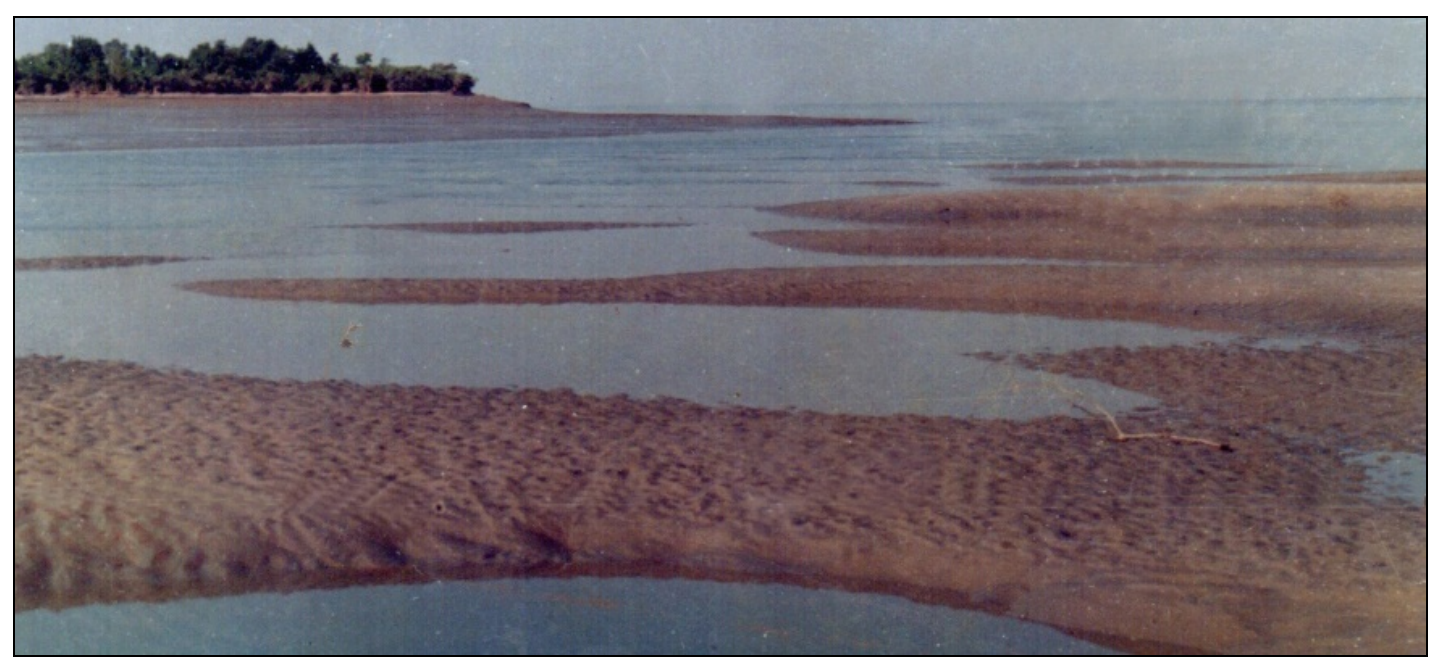

Fig. 21: Linearly arranged sandy shoals and megaripples on the mid channel bar near mouth of Thakuran. Megaripple top is partially planed-off. 


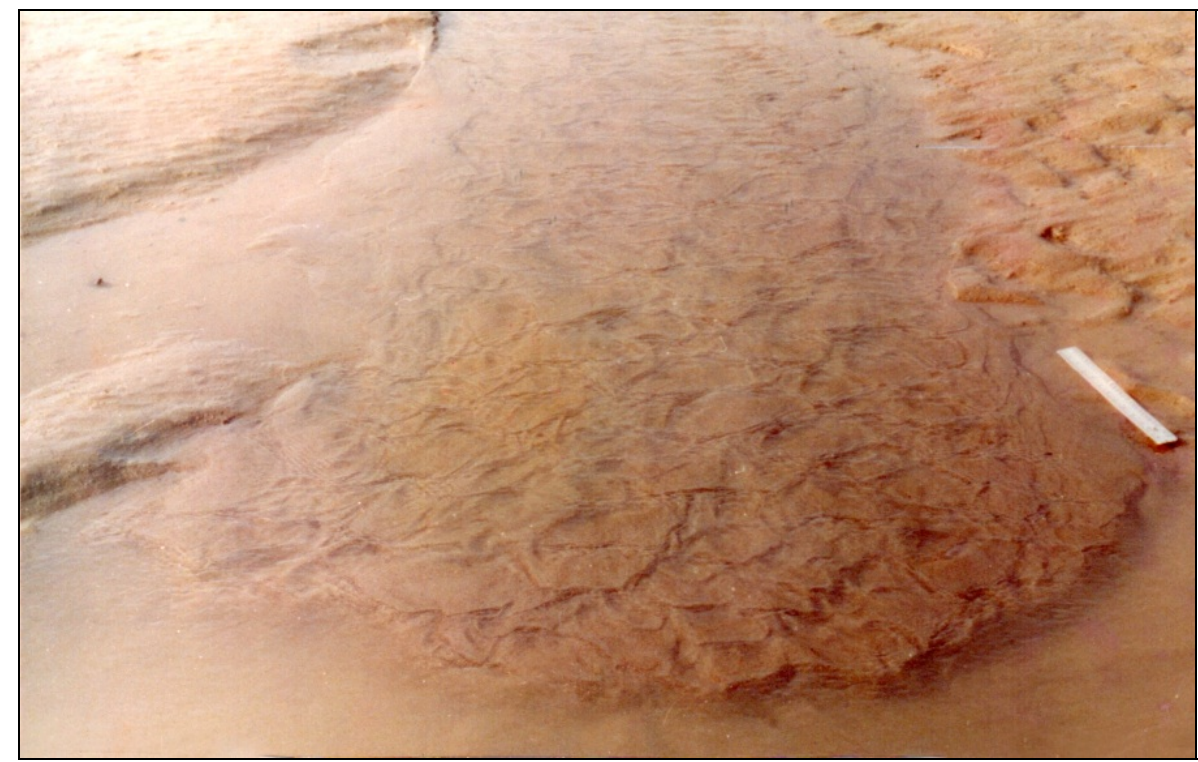

Fig. 22: Dissected channel and microdelta. The delta lobe is clearly seen. Surface marked by linguoid ripples. Dissected channels cut across the ripple trains. Note also the draining out of a channel from the microdelta on the left of the figure. Scale is 30 $\mathrm{cm}$.

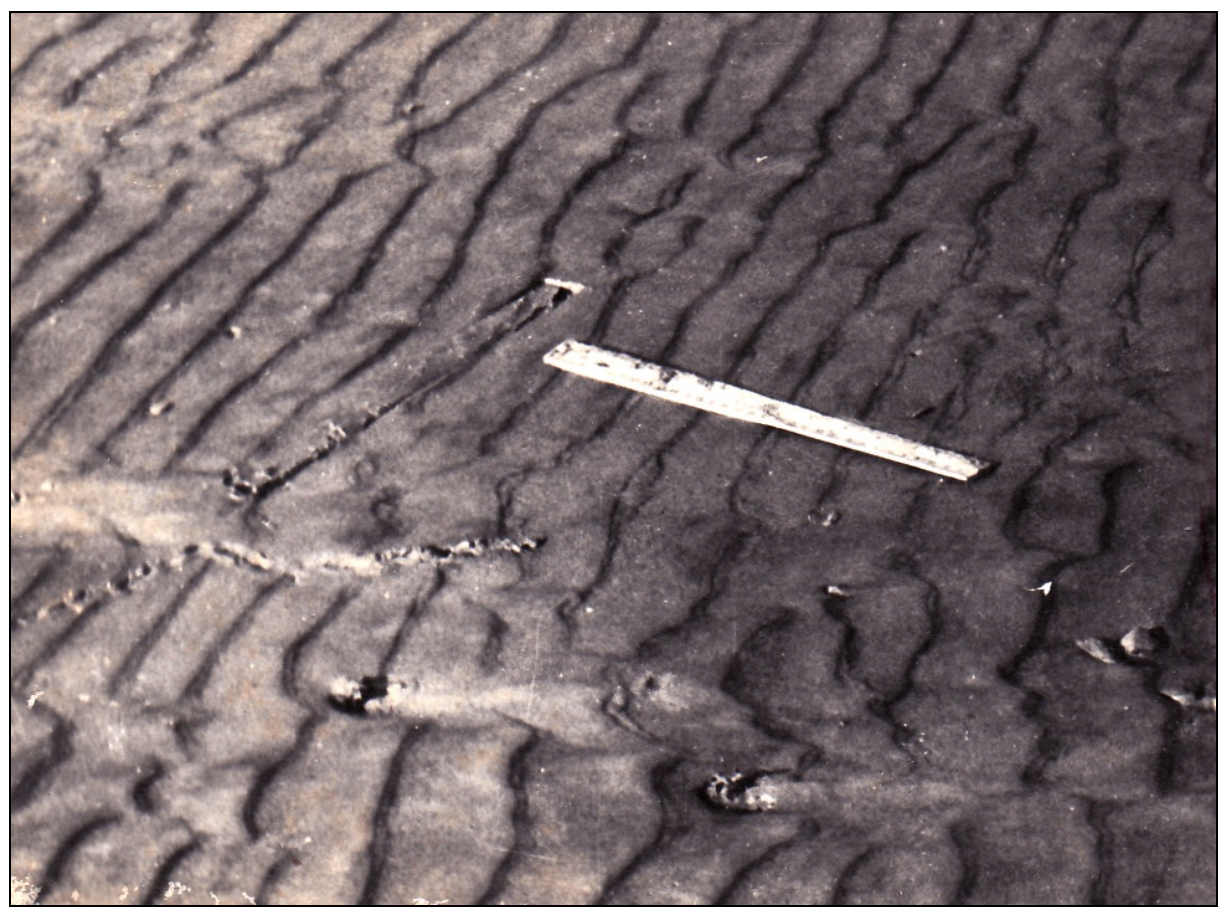

Fig. 23: Wave ripples grade to straight-crested ripples. Current crescents are opposite to ripple lee-directions and indicate reversing of tidal currents. Ruler is $30 \mathrm{~cm}$. 


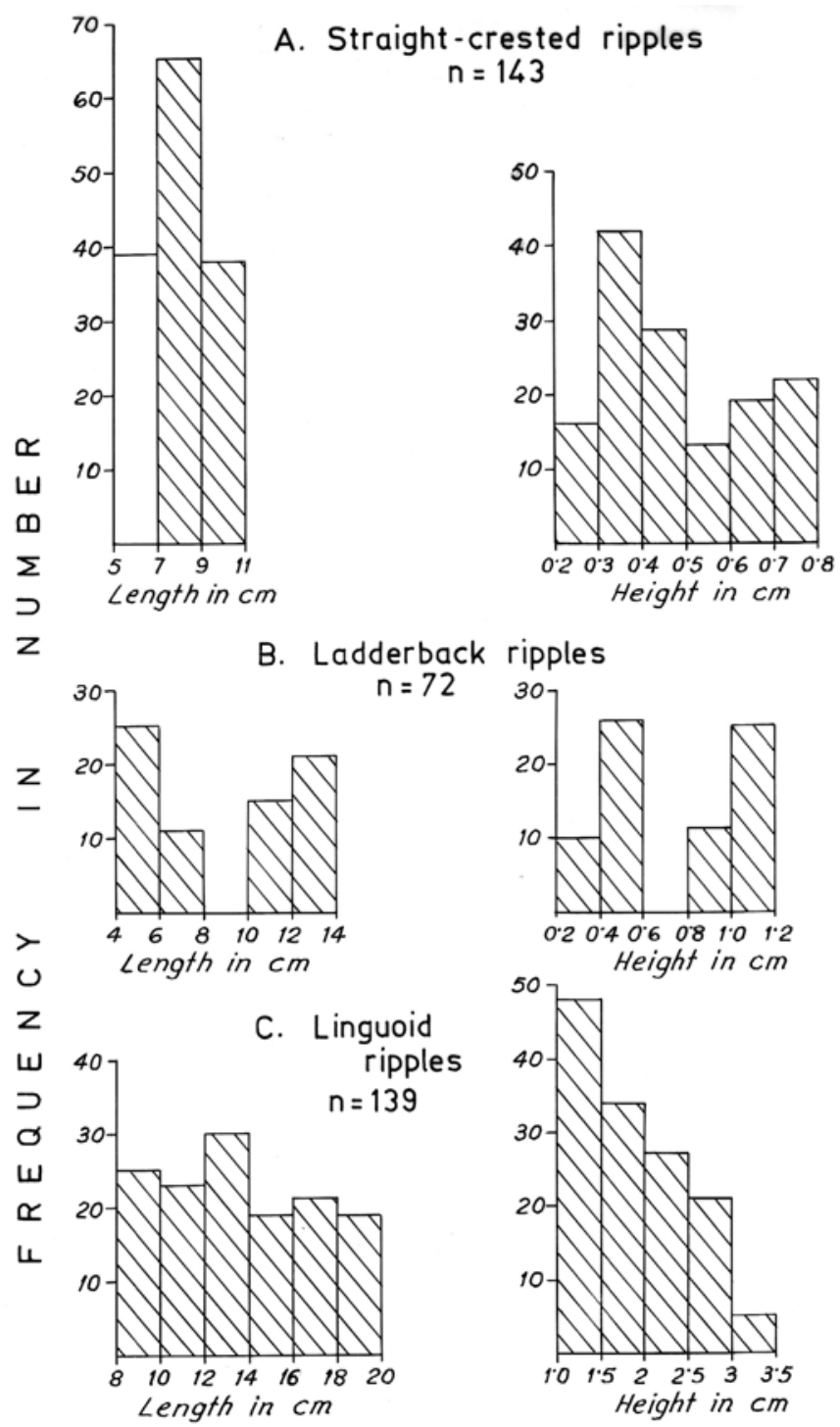

Fig. 24: Histograms of distribution of Length and Height values of various ripples.

\section{i) Straight Crested Ripples}

These ripples appear as both symmetric and asymmetric forms. They have more or less straight crests. Crestal trains of successive ripples run parallel for a few meters. The surface undulation is minor because of low ripple heights ranging from 0.25 to $0.8 \mathrm{~cm}$ (Fig. 23). Wave length is short and ranges from 5 to $11 \mathrm{~cm}$ (Fig. 24A). A good linear correlation exists between ripple wave length and height (Fig. 25B). 
The straight-crested ripples are formed by local, short-period, wind-driven waves that are formed in shallow waters. Thus, their origin is related to periods of moderate to strong winds active on sand flats.
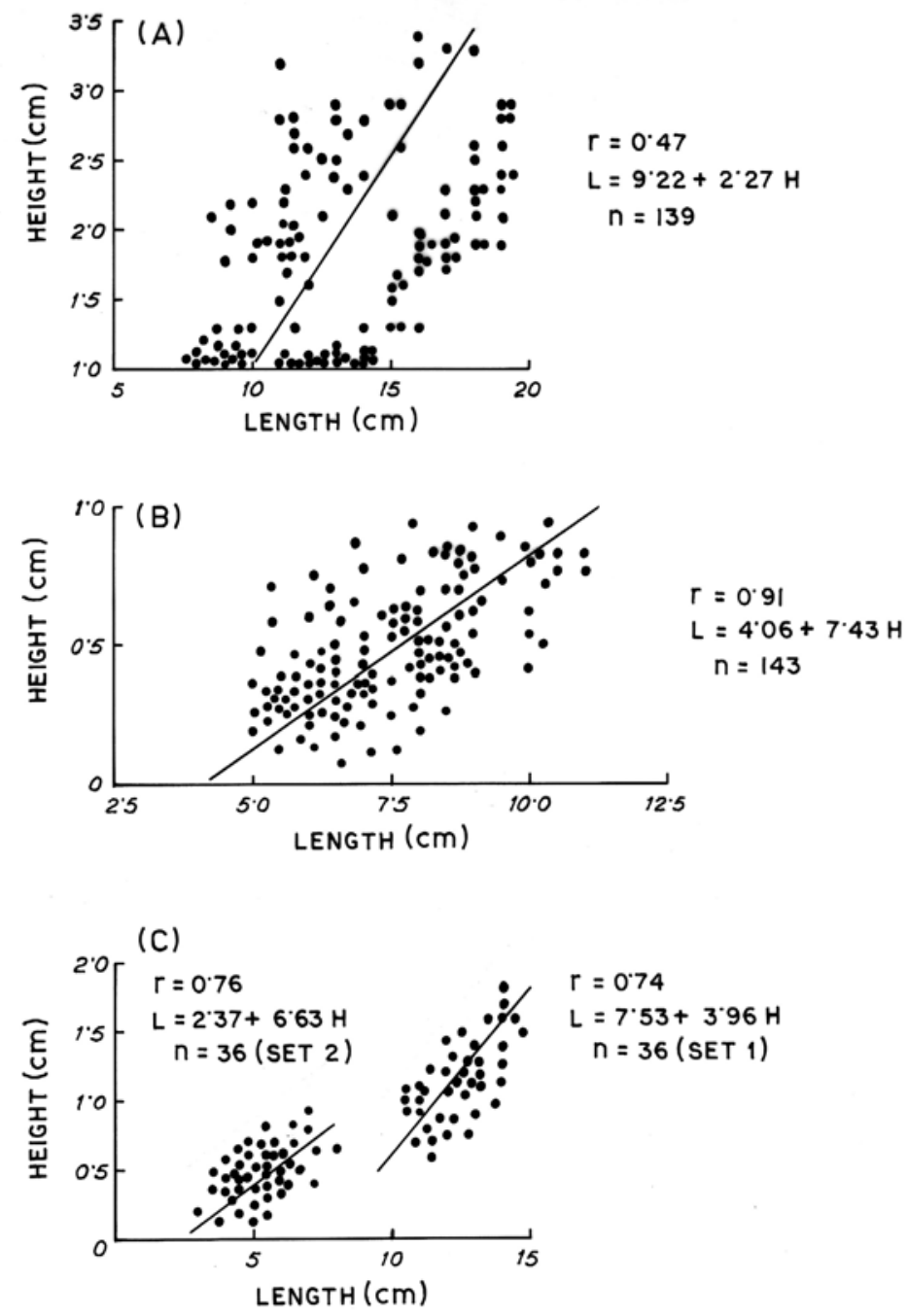

Fig. 25: Plot of Length versus Height of Linguoid ripples (A), Straight-crested ripples (B) and Ladder-back ripples (C).

\section{ii) Linguoid Ripples}

These ripples are crescentic in plan. Their crests are arcuate or tongue-like having downcurrent closures (Figs. 5, 13 \& 22). The ripples produce appreciable surface undulations as height ranges from 1 to $3.4 \mathrm{~cm}$ (Fig. 24C). Wave length ranges from 8 to $19 \mathrm{~cm}$. plots of wave length versus height reveal a nice positive linear correlation (Fig. 25A). 
Linguoid ripples commonly occupy creek floors on mid channel bars where the water depth is around a meter, particularly during the flooding time. They are generally oriented parallel to flood flow but may also occur ebb-oriented. These ripples display definite field evidences of crestal reversal with tide. Linguoid ripples laterally grade to small wave ripples or to straight-crested ripples with shallowing water depth.

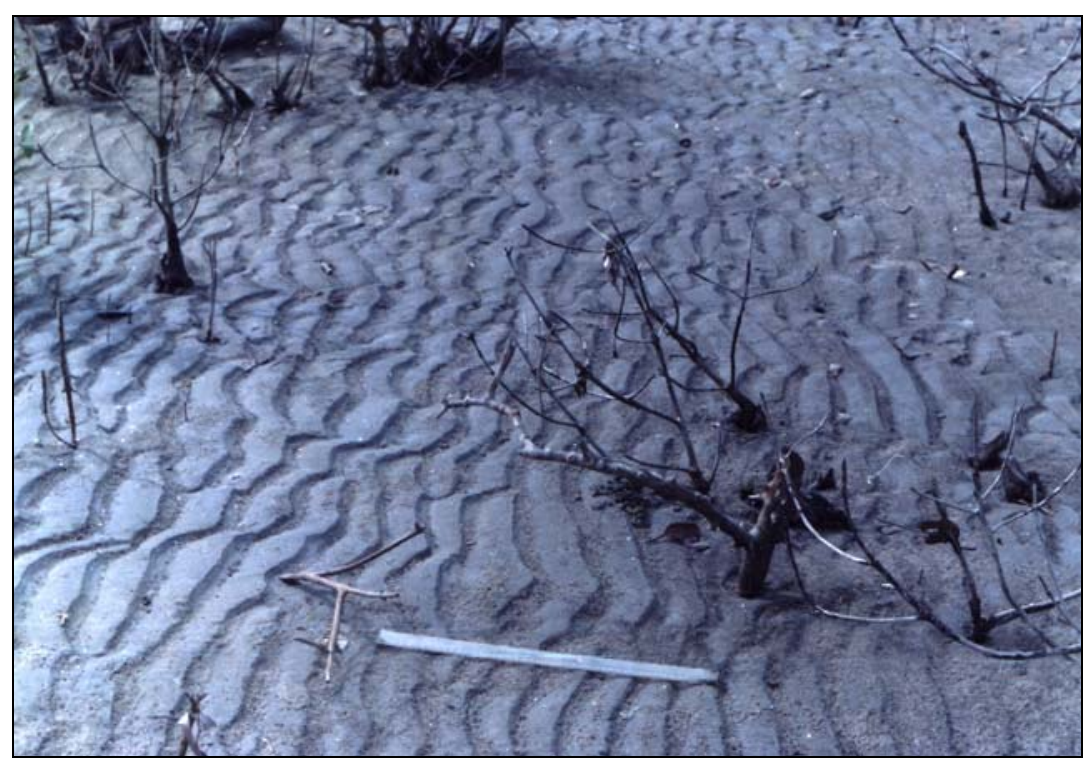

Fig. 26: Wave ripples on intertidal sand flat at Dhanchi. Ebb flow is towards left of the photograph. Note the flattening of the ripple crests and narrowing of ripple troughs. Upright trunks of mangroves are seen. Scale is $30 \mathrm{~cm}$.

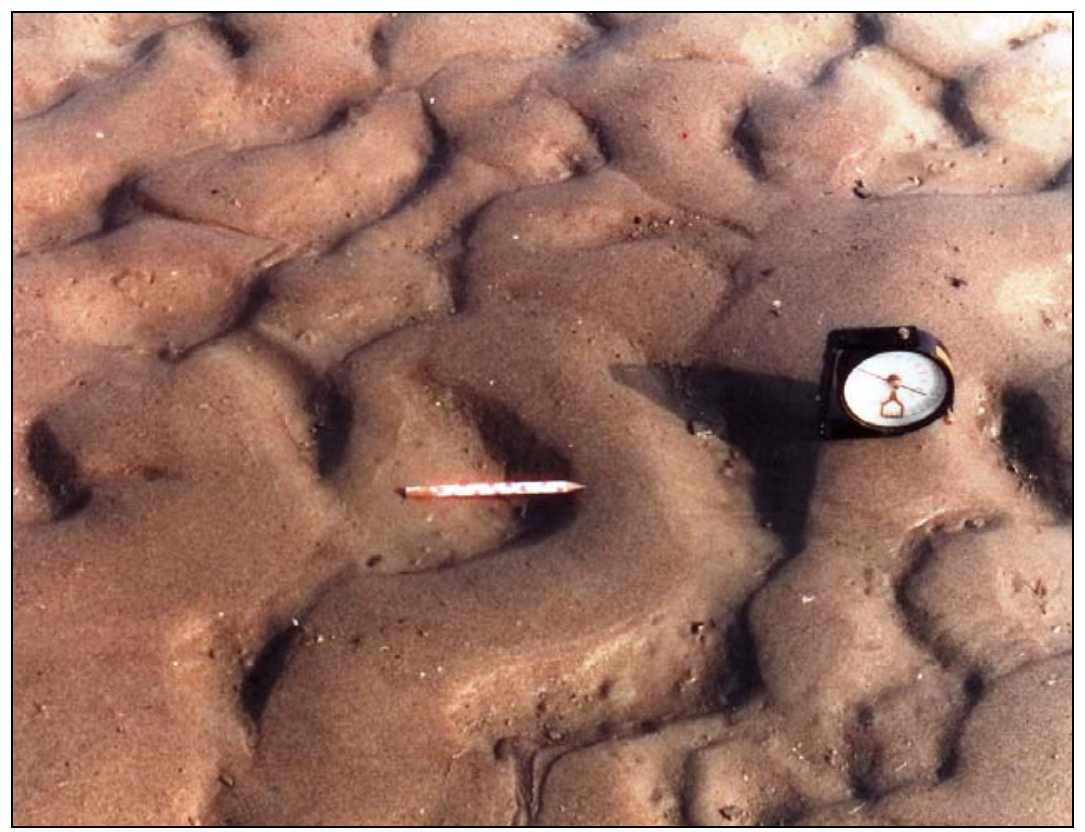

Fig. 27: Flat-topped linguoid ripples. Note the narrowing of the trough compared to width. Pencil is $12 \mathrm{~cm}$. 


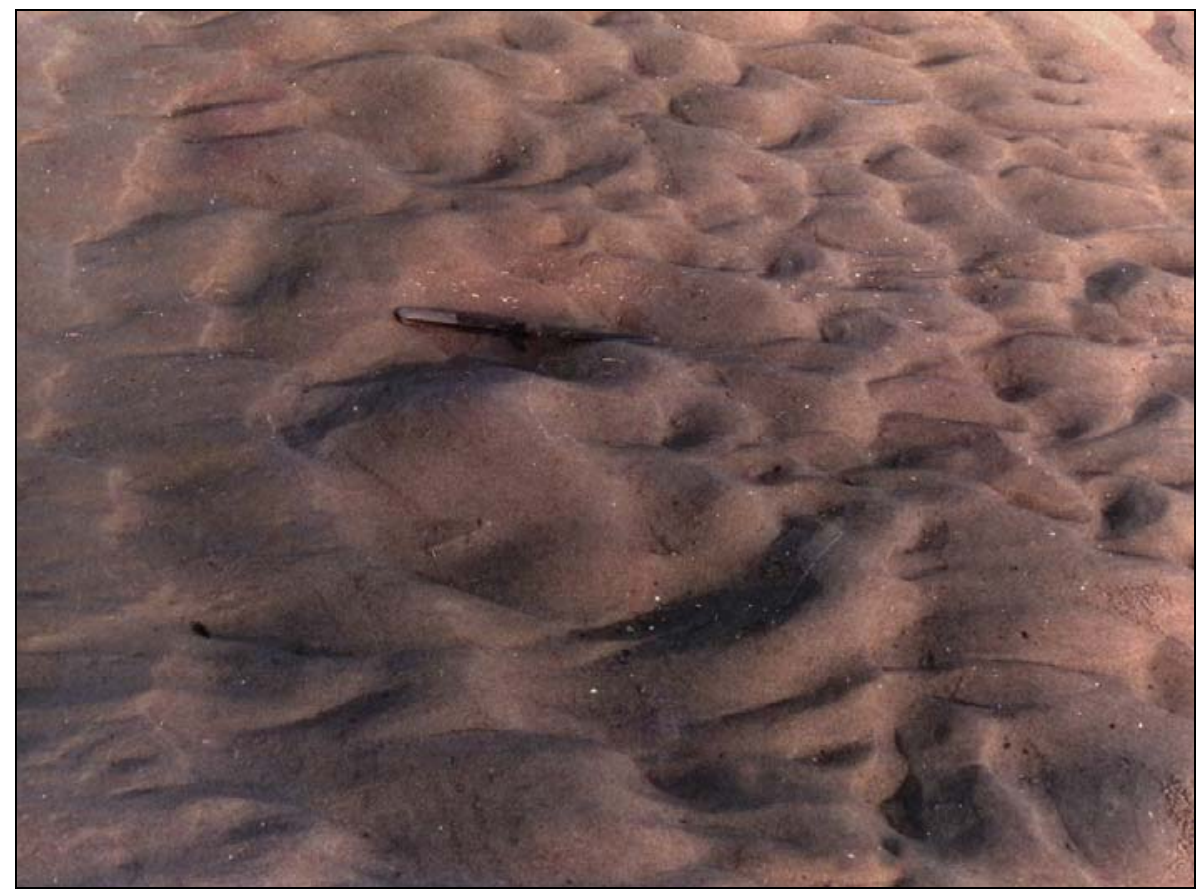

Fig. 28: Flat-topped linguoid ripples show increase flattening with increasing slope near trough margin. Knife is $26 \mathrm{~cm}$.

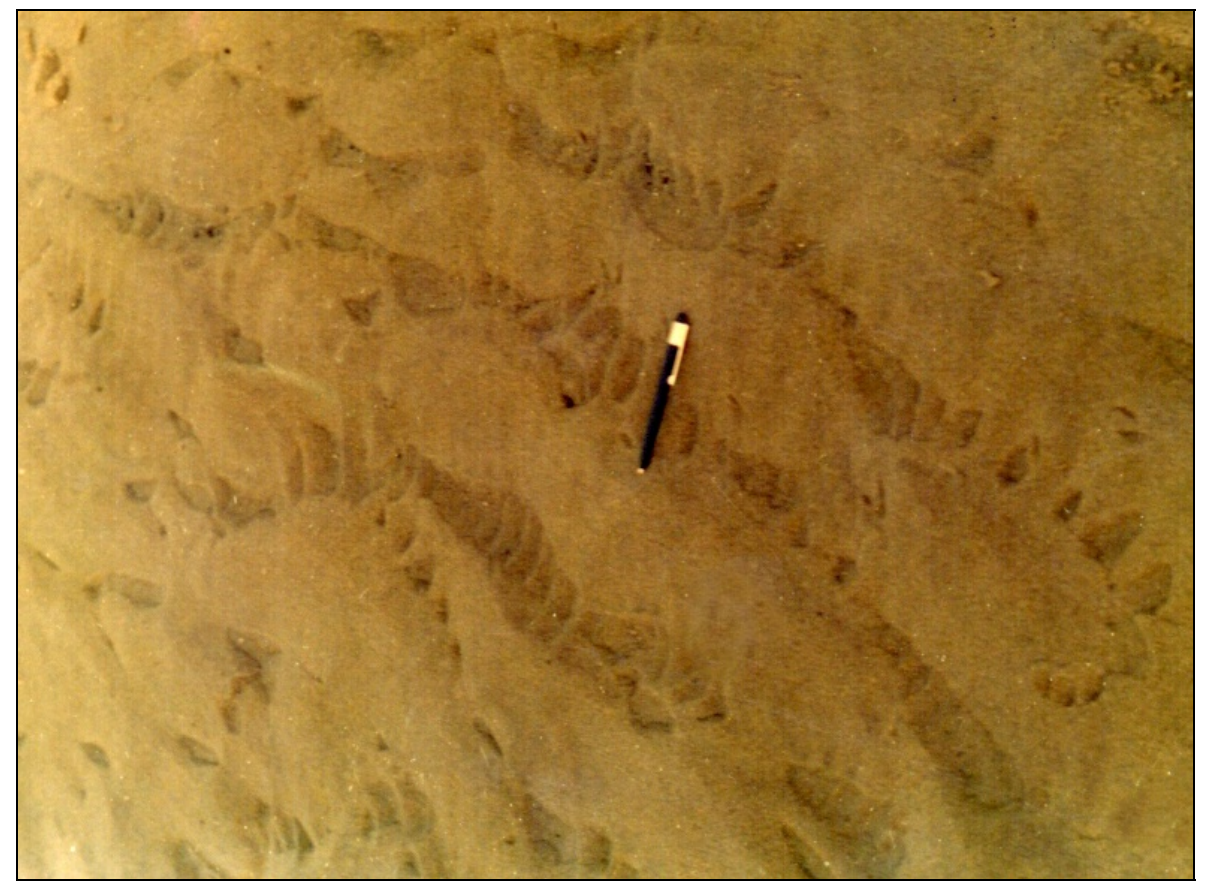

Fig. 29: Flattening of the ripple crests has left very little space for the troughs. Ripple patterns appear partially on the troughs. Pen is $15 \mathrm{~cm}$. 


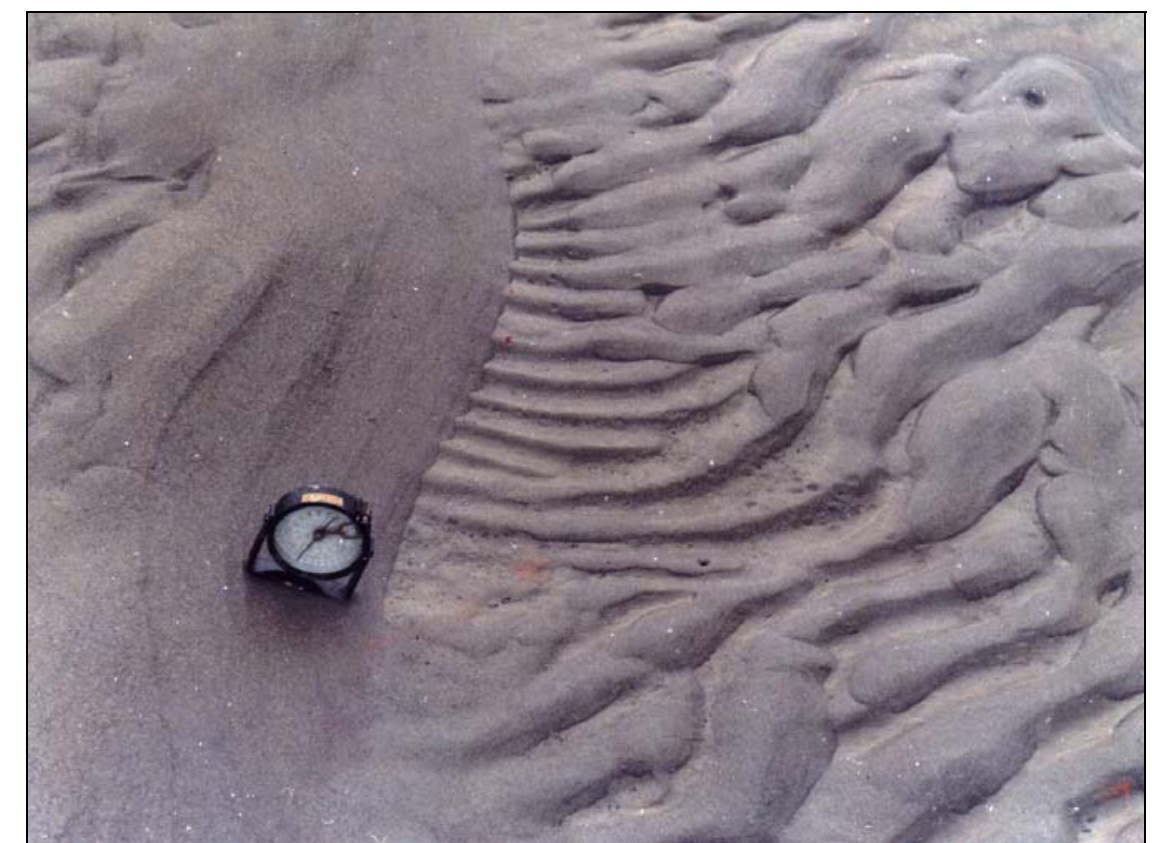

Fig. 30: Capped-off ripples. Wave ripples are modified to linguoid current ripples by the thin film of water during subaerial emergence. Sudden truncation of the ripple trains (marked by clinometer) is due to shear drag of surface ripples during emergence.

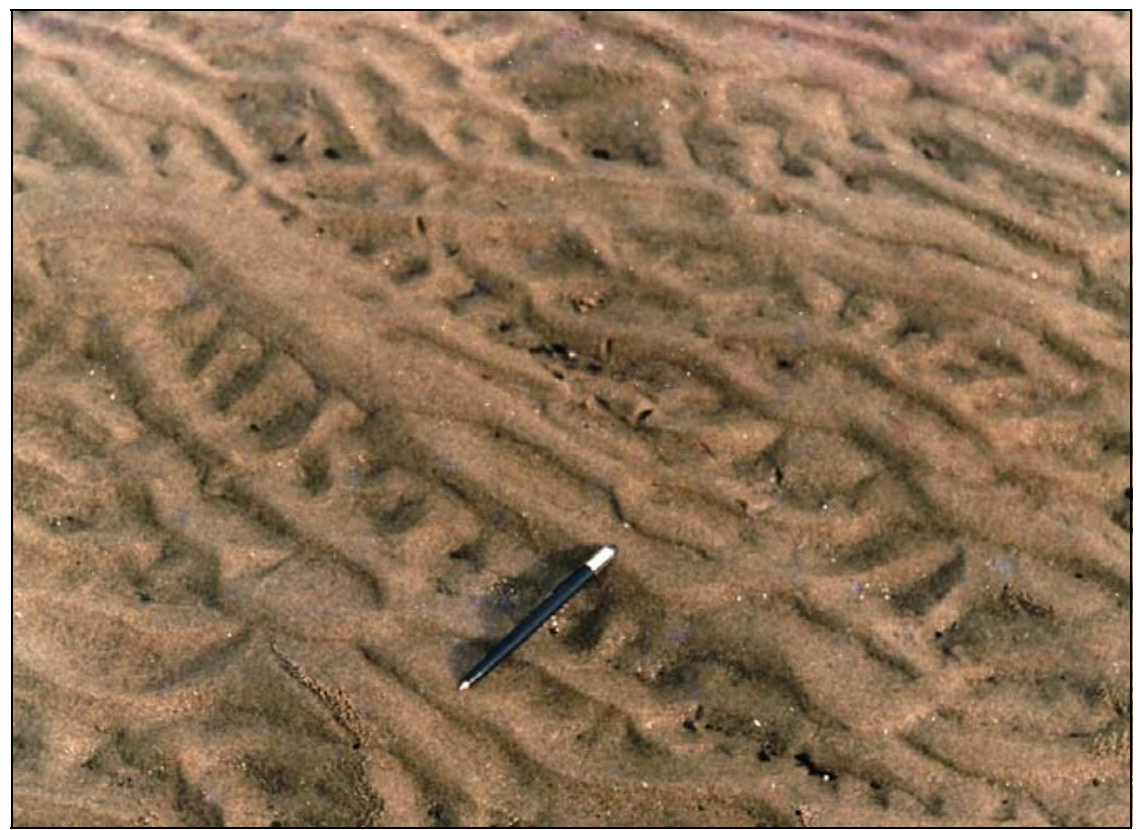

Fig. 31: Ladder-back ripples. An older set of ripples is preserved in the trough of a younger set formed at right angles. The younger set exhibit multiple crests. Pen is $15 \mathrm{~cm}$. 
Open access e-Journal

Earth Science India, eISSN: $0974-8350$

Vol. 9 (II), April, 2016, pp. 53 - 103

http://www.earthscienceindia.info/

\section{iii) Small Wave Ripples}

These ripples are asymmetric in plan and exhibit crestal sinuosity. They show close association with straight-crested ripples. They have a steep lee-slope and a very gentle stoss slope (Fig. 26). Wave length ranges from 7.0 to $8.5 \mathrm{~cm}$ and height from 0.08 to $0.11 \mathrm{~cm}$. A positive linear correlation exists between their wave length and height.

Small wave ripples occur as strike-wise variation from straight-crested ripples and reflect a shallow-water origin on the mid channel bar surface. These ripples are also formed by wind-driven waves generated in shallow waters.

\section{Some Characteristics Ripple Types and Other Structures of Tidal Origin}

Although not exclusive of intertidal flat some ripple types viz. flat-topped ripples, ladder-back ripples and double-crested ripples are very characteristic of intertidal zone (Terwindt, 1988) and have been studied from the mid channel bars of the Thakuran River.

\section{Flat-topped or Capped-off ripples}

They occur superimposed on sandwaves and on crests of megaripples. The flattening of the crests is generally prevalent in linguoid ripples and asymmetric wave ripples. In flattopped ripples, the ripple troughs are very narrow compared to the width of the crests (Fig. 27). The magnitude of the crestal flattening increases with increasing slope of the intertidal flat as the ripples approach the megaripple trough margins (Fig. 28). In extreme cases the ripple crests are modified to more or less flat surfaces keeping very little space for the ripple troughs (Fig. 29).

Sometimes the wave ripples with sinuous crests are seen to be changed into linguoid forms during final draw down of water. At places the crest of superimposed younger set of interference ripples are only flattened leaving the crestal trains of the earlier set almost intact. The narrow elongated troughs of ripples are ornamented with earlier set ripple crests obliquely or at right angles to the elongation direction of ripple troughs (Fig. 29).

The mechanism of formation of flat-topped ripples is attributed to erosion (Fig. 30) induced by enhanced shear of falling water or due to backwash at late stage emergence (Klein, 1970). According to Reineck and Singh (1980) the flattening is caused by 'capillary waves' which are produced by strong winds on the water surface. Flat-topped ripples are typical, though not exclusive for tidal deposits (Terwindt, 1988).

\section{Ripples with Double Crests}

Some domains of ripple in the intertidal flat display ripple with double crest lines having spacing about 5 to $6 \mathrm{~mm}$ in between. The ripples are generally asymmetric in profile and have almost straight crests which often terminate laterally against the linguoid ripples. Double-crested ripples may form under the following conditions: i) in stagnant pools of very shallow water by wind-generated waves and ii) in ripple flats under wave-cum-current flow (Figs. 31 \& 32). The double-crested ripples most commonly occur in intertidal zones (Klein, 1970; Reineck and Singh, 1980; and Terwindt, 1988). Yet, they are not exclusive for such environment. 


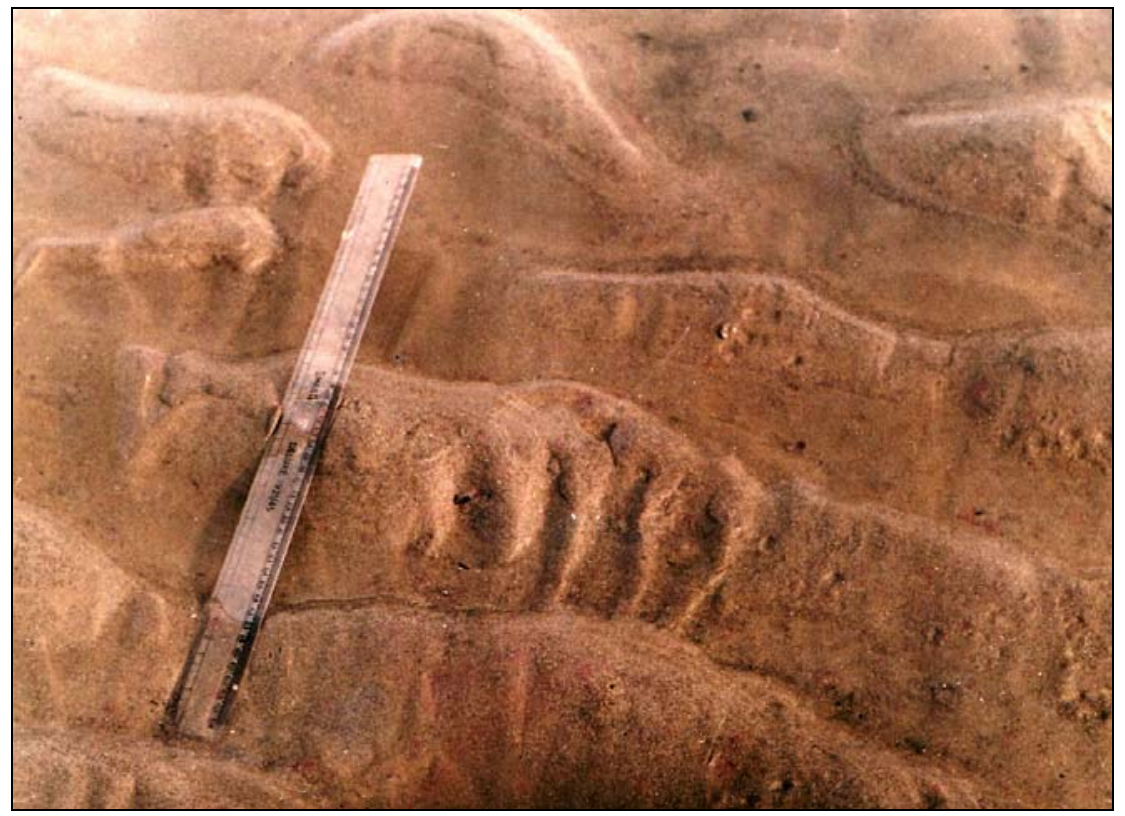

Fig. 32: Ladder-back ripples showing double crests in the younger set. An older ripple set is preserved in the troughs of a younger set aligned at right angles. Note the large scale of the younger ripples and flattening of their crestal trains. Scale is $45 \mathrm{~cm}$.

\#

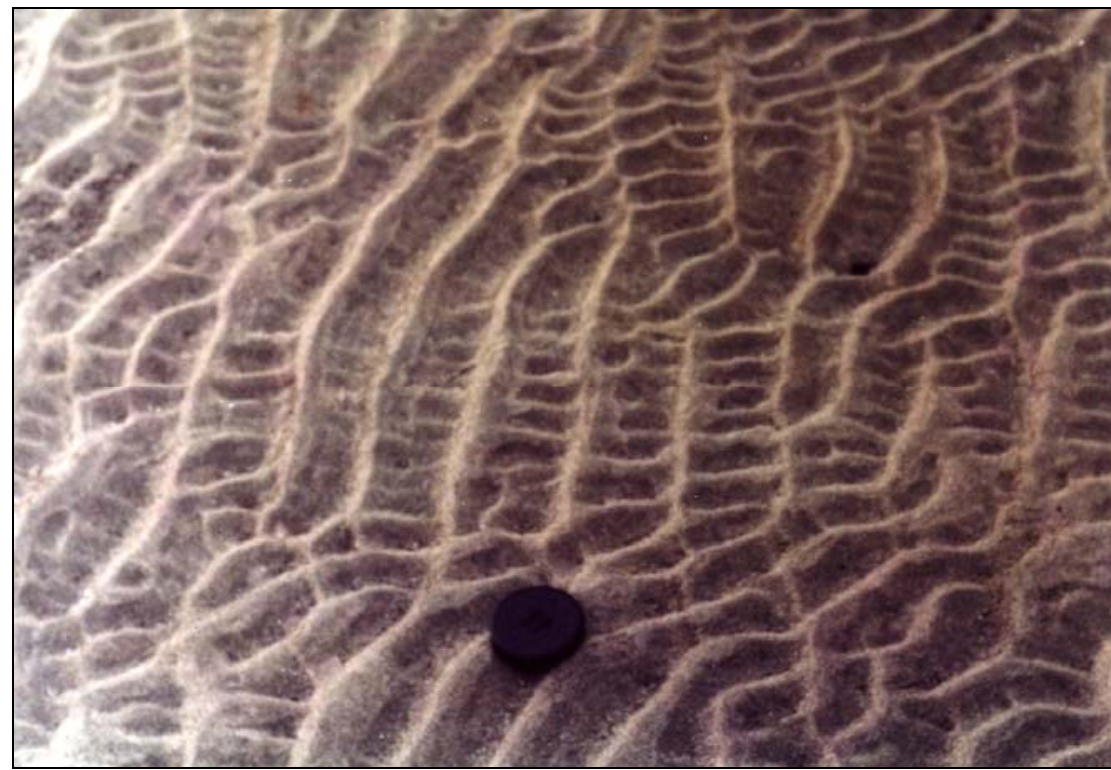

Fig. 33: Interference ripples showing ladder-back form. Two different sets of ripples show oblique to perpendicular crestal alignment. Cap is $5 \mathrm{~cm}$ diameter. 


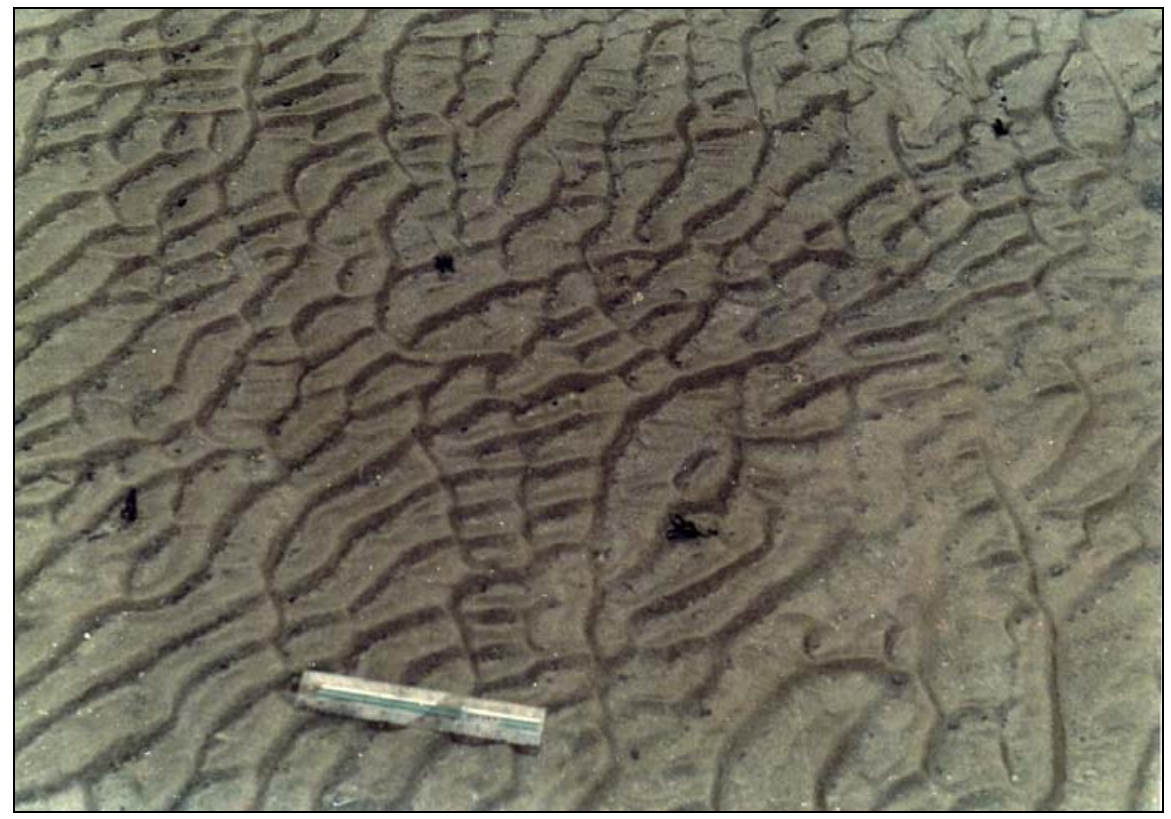

Fig. 34: Complex network of ripple-trains are seen. Ripple crests show change of curvature with flow reversals prior to emergence. Straight-crested current ripples are superimposed on smaller sinuous current ripples with trends mutually perpendicular to one another. Scale is $15 \mathrm{~cm}$.

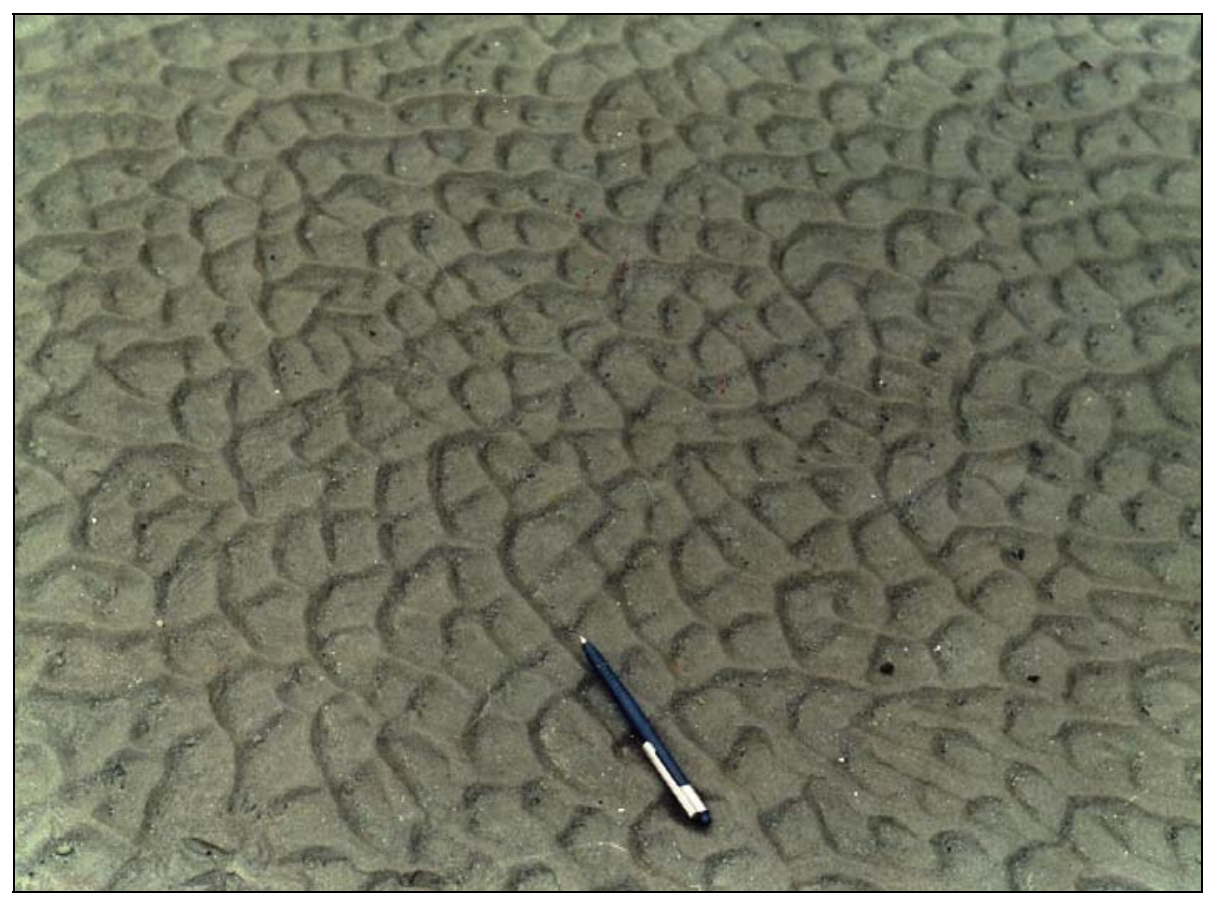

Fig. 35: Interference ripples showing polygonal crestal patterns. Towards the upper left portion of the photograph the ripples grade more to the ladder-back type. Pen is 15 $\mathrm{cm}$. 


\section{Ladder-back Ripples}

These are interference ripples in which two sets of superimposed ripples are oriented essentially at right angles to each other (Davis, 1983). In most occasions, there is a difference in the scale of formations of the two sets and the smaller ripples run along the troughs of larger ripples. In the present field many different configurations for these ripples exist varying from simple ladder-back forms (Fig. 33) to complex network of superimposed ripple trains (Figs. 34, 35 \& 36). The superimposed small current ripples often occur on straight or sinuous-crested ripples having crestal trends almost at right angles to each other (Fig. 34).

Wavelength of the larger set of the ladder-back ripples ranges from $10-14 \mathrm{~cm}$ and that of the smaller set from $4-8 \mathrm{~cm}$. The corresponding height of ripples ranges from $0.8-$ $1.2 \mathrm{~cm}$ and $0.2-0.6 \mathrm{~cm}$ (Fig. 24B). The plots of wavelength versus height of these two sets of ripples reveal a strong positive linear correlation (Fig. 25C).

Complex network of ripple trains characterizes many sandy intertidal surfaces subjected to flow reversals. Change in curvature of the ripple crests often occurs due to change in flow directions prior to emergence. The bidirectional ripple fabrics with changing ripple trains point to their tidal origin. Similar ripple structures have also been reported from other tidal settings (Barclay and Davies, 1989).

Reduction of water depth particularly during the ebb phase controls the size and orientation of current ripples. With the decline of water depth the size of current ripples decreases resulting in superimposition of smaller ripples on the larger sets. In many occasions in the present case described here the smaller ripples run along the troughs of the larger ripples, because the water level drops below the crestal heights of the larger ripples. In addition, ladder-back ripples of other kind originate through interference between two simultaneously operating wind induced waves.

The lowering of water depth also produces double crests in the larger set ripples of the ladder-back variety (Figs. 33 \& 36). The secondarily formed parallel ripples occur along the troughs of the earlier larger set. Tidal current bottom shear drives the initial current ripples until the water level drops to a critical depth when ripple migration ceases. Yet the shear stress on the troughs where water depth is slightly higher, may still be capable to move sand grains and create secondary ripples of smaller amplitudes (Klein, 1970).

\section{Relics of Ripple Crests}

The wave ripples in the intertidal flats are often modified by current during a falling water stage. If some water is retained in the troughs at the time of subaerial exposure, the lee faces of the ripples suffer partial destruction by wind-driven water and leave only the relics of ripples crests. The wind-driven waves often create small wave ripples along troughs of the earlier ripple set (Fig. 37). Reineck and Singh (1980) have described similar relics of ripple crests from the North Sea tidal flats. 


\section{Water Level Marks on Ripple Surfaces}

Water level marks also known as etch marks (Klein, 1970) are supposed to be the modification structures characteristic of intertidal sand flat environment. Such etch marks form during punctuated fall in water level on emerging mid channel bars. Etch marks occur on both megaripple and ripple surfaces (Fig. 38).

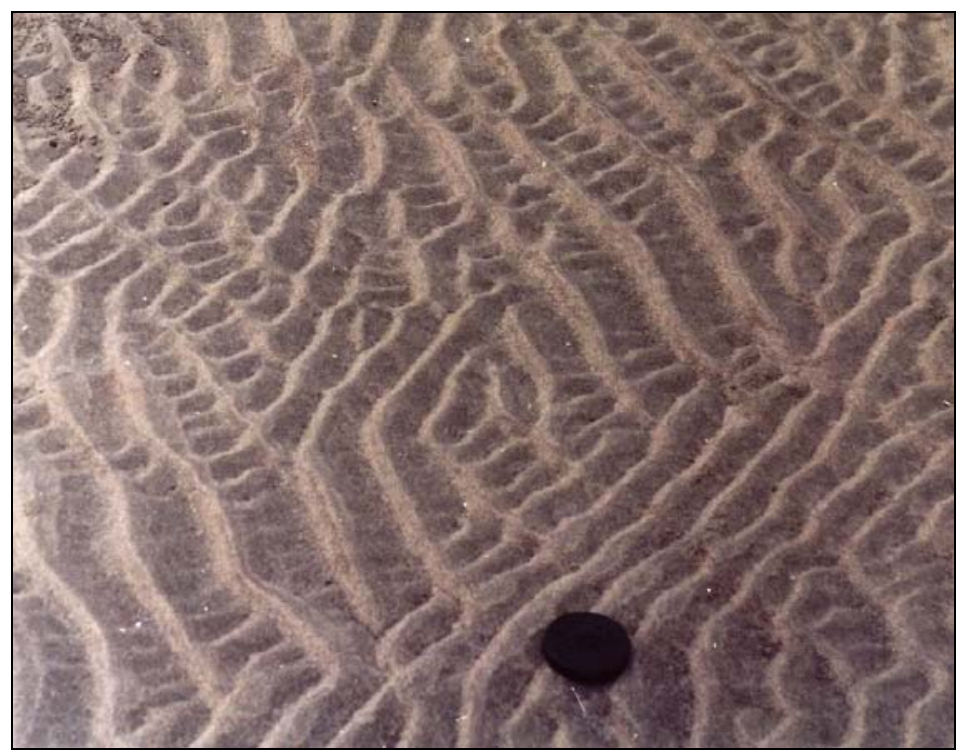

Fig. 36: Ladder-back ripples. Bidirectional ripple trains are seen on intertidal sand flat. Ripple sets reflect wind-and/or tide-controlled reversals of flow direction in very shallow water. An older ripple set is visible as short segment of ripple crest preserved in the troughs of a younger set formed at right angles.

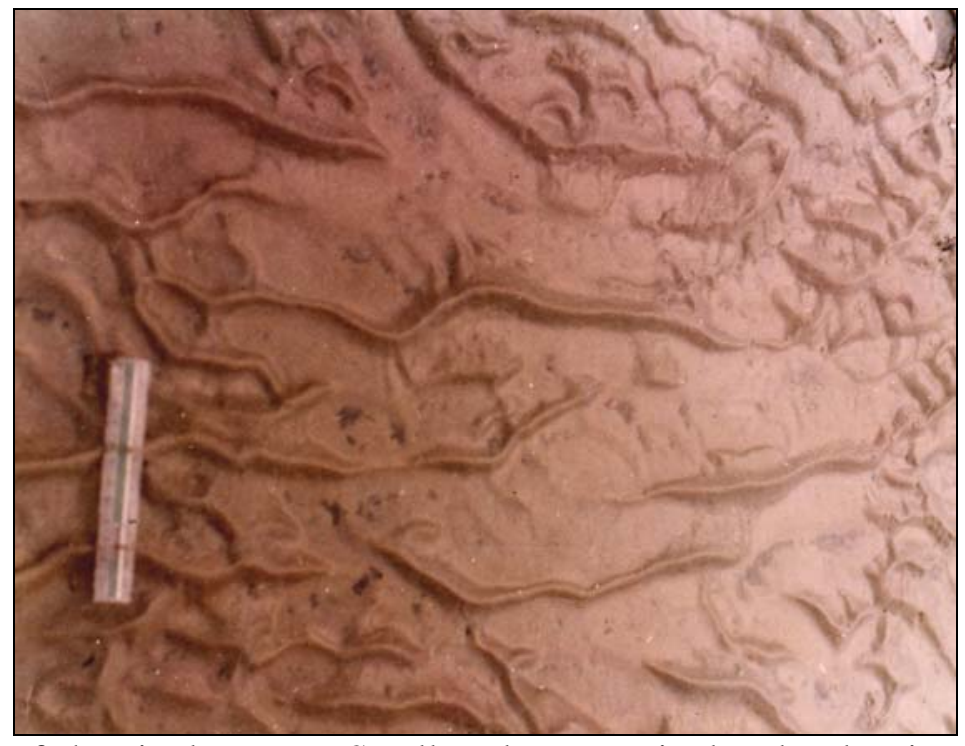

Fig. 37: Relics of the ripple crests. Small-scale wave ripples develop in the troughs. The relatively larger-ripples are destroyed by wind-driven current. Scale is $15 \mathrm{~cm}$. 


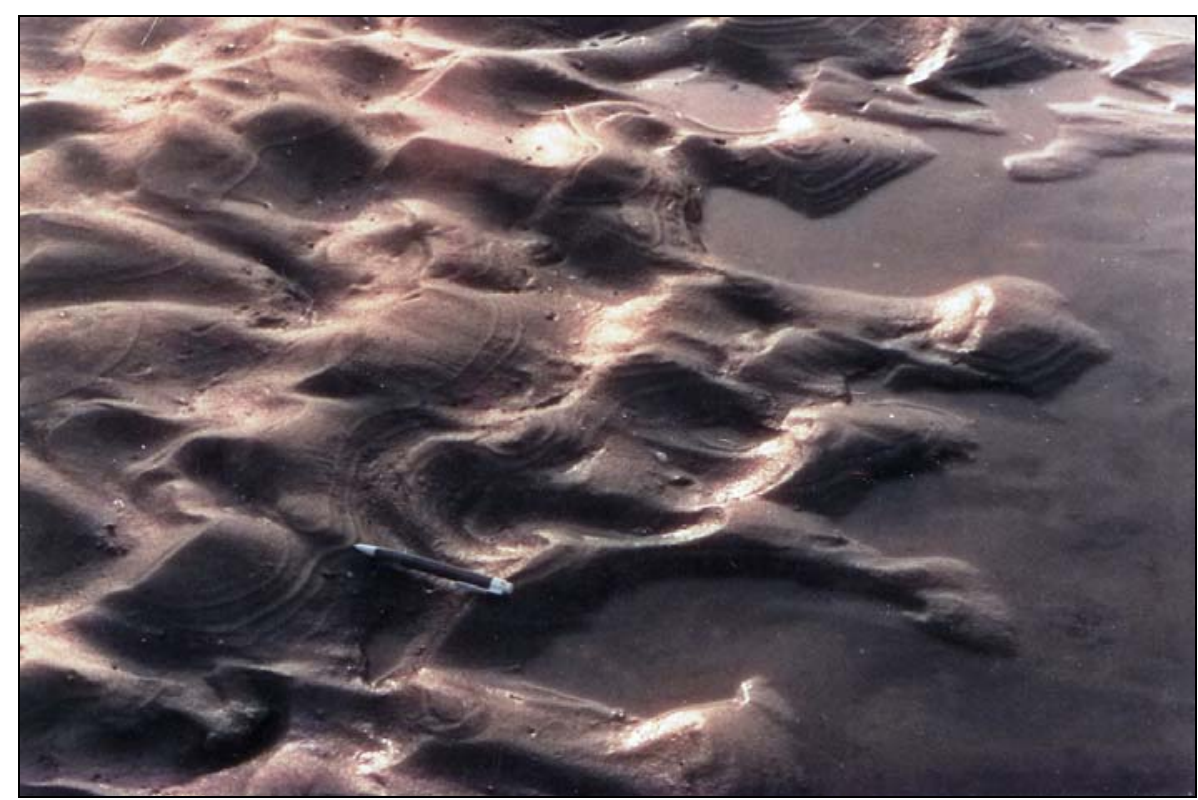

Fig. 38: Water level marks on ripple slopes formed during irregularly (in phases) falling water level.

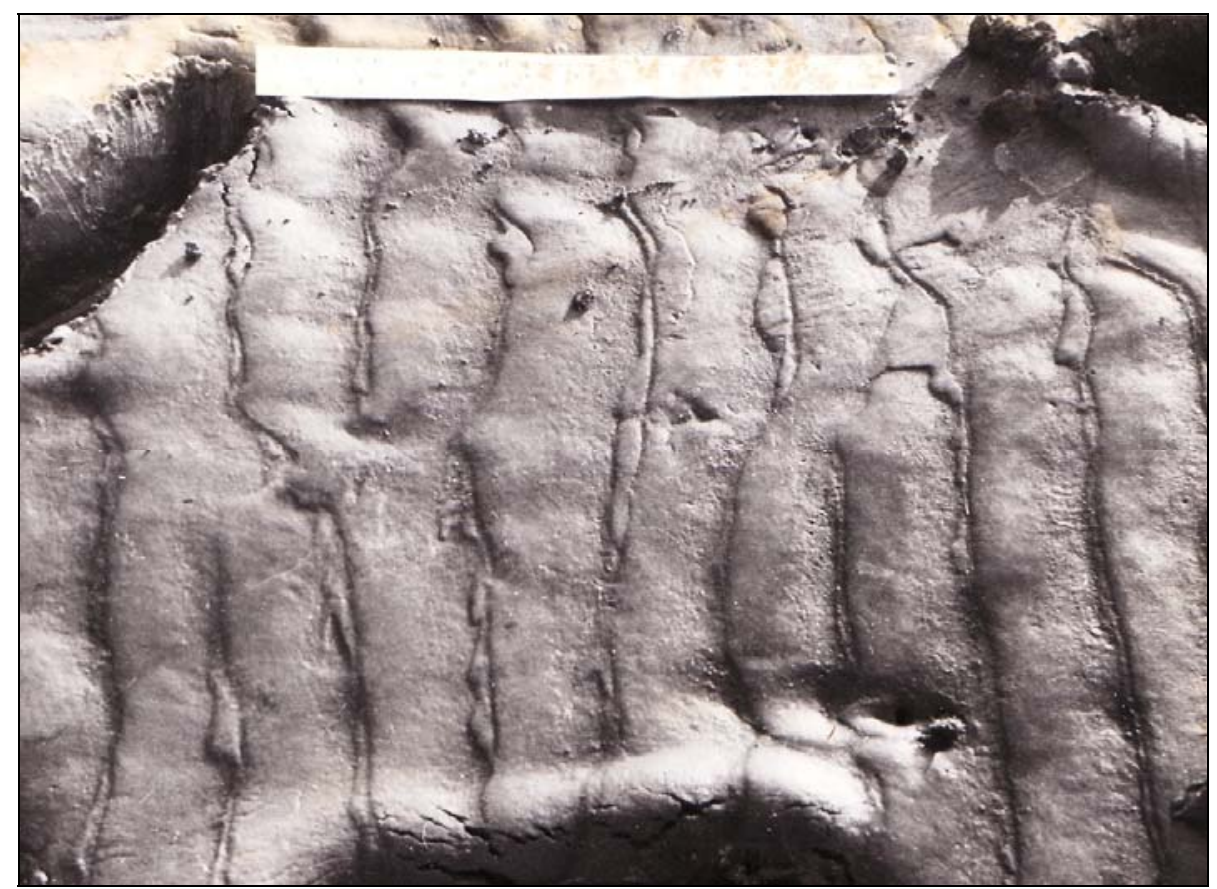

Fig. 39: Wave ripples modified by swash. Crests of ripples are rounded. Thin veins of sand occupy the narrow ripple troughs. Note variations in width of the veins. 


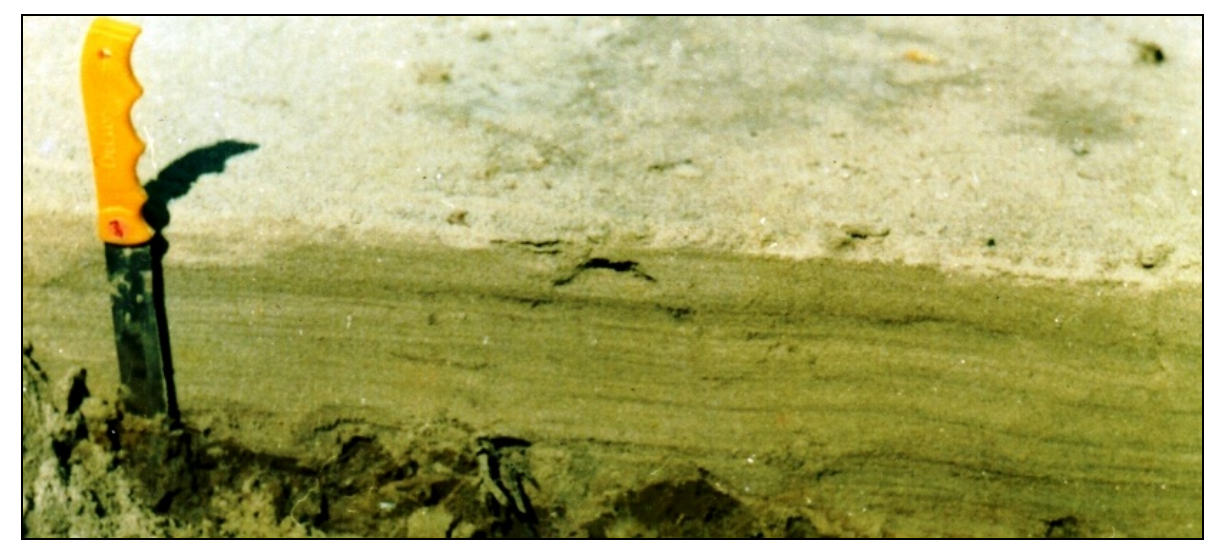

Fig. 40: Alternating sand-mud couplets at Dhanchi point bar. Knife is $26 \mathrm{~cm}$.

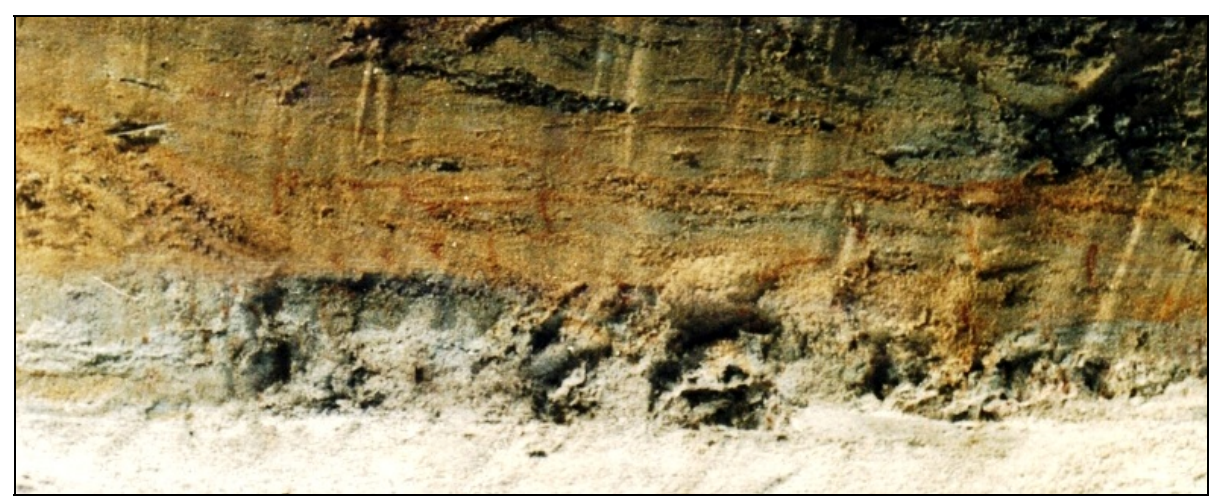

Fig. 41: Planar tabular cross-bedded unit intercalated with mud drapes towards the right of the photograph. Note the lateral gradation of the cross-laminae to flaser bedding towards the left.

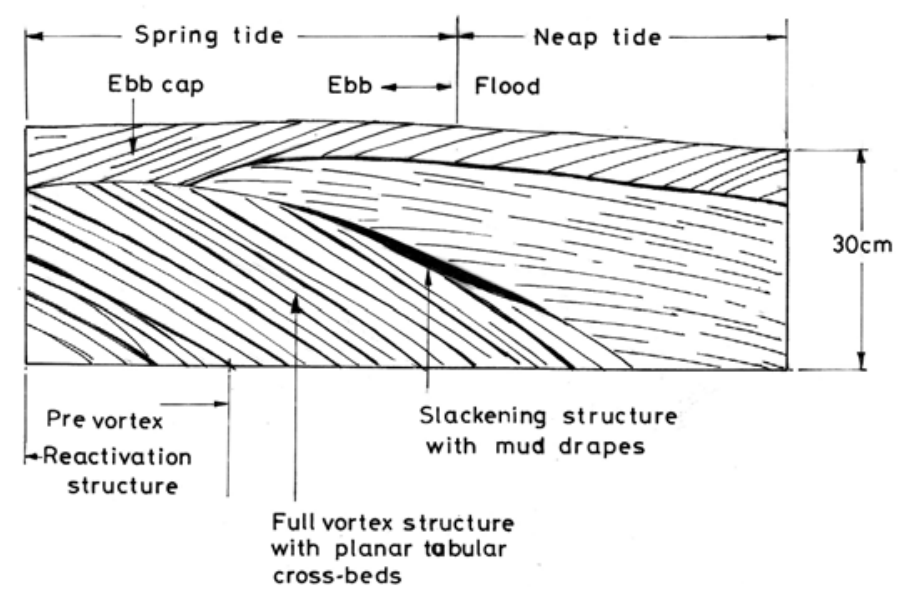

Fig. 41A: Cross section through a megaripple with a succession of tidal bundles containing pre-vortex, full vortex and slackening structures as response of single spring tide (Field sketch of a section adjacent to trench in Fig. 41) 
Following the suggestion of Klein (1970) the mechanics of water level marks can be explained as follows. As the tide ebbs and progressively exposes different parts of the mid channel bar, different scales of pools appear in the troughs of ripples and megaripples. Low velocity open-channel flow also occurs in troughs of larger bedforms. A slight increase in surface wind velocity forms a small wave pulse on the pool surface. This wave pulse laps against the slip face of the bedforms (megaripples and ripples) and erode parts of the bedforms at that water level. The gradual fall in water level coupled with repeated microwave pulses produce the etch mark. Continuation of this process produces a series of parallel water recession marks.

\section{Sedimentary Structures of the Point Bars}

\section{Longitudinal Ripples}

These ripples named by Van Straaten (1961) are generally straight-crested without bifurcation. The ripple crests run more or less parallel to current and the wave propagation is at right angles to the current direction. Although wave action is supposed to be the major force for their formation, a simultaneous weak current flowing parallel to the crests also controls their shape (Reineck and Singh, 1980).

The longitudinal ripples dominate on muddy stable substratum. These ripples are generally symmetrical in form; their length ranges from $0.5-2.5 \mathrm{~cm}$. The ripple crests continue uninterrupted for 10-100 cm. Reineck (1972) described longitudinal ripples as erosive form in mud with about $40 \%$ of sand. Longitudinal ripples are characteristics of very shallow water environment and generally form during falling water stage with eventual emergence.

\section{Symmetrical Wave Ripples}

These ripples have more or less symmetrical profiles and straight crests. Instead of having pointed crests and rounded troughs typical for wave ripples, these ripples possess rounded crests. The rounding of crests is supposed to be a modification feature and results due to reworking of wave ripples during the process of emergence. Wave length of these ripples ranges from $5-6 \mathrm{~cm}$ and height from $0.5-0.6 \mathrm{~cm}$.

In many places, thin veins of sand (2 to $5 \mathrm{~mm}$ wide and a few $\mathrm{cm}$ long) occupy the narrow ripple troughs. The veins also show variations of width very commonly (Fig. 39). The veins thus, appear as longitudinal bedforms and are good indicators of subaerial emergence or quasi-subaerial emergence of the ripple surface.

In sectional manifestations these ripples show unidirectional foreset laminae. The forward motion of the wave somewhat stronger than the backward motion produces foreset laminae (Reineck and Singh, 1980). The backward motion of a wave is strong enough to produce the symmetry of the ripples but unable to produce foreset laminae. The rounding of ripple crests takes place during the phase of ripple emergence. The sand veins perhaps indicate accumulation of transported sand along the ripple troughs during subaerial exposures of the ripple surface. Their longitudinal alignment is chiefly controlled by the transportation of sand across the direction of wave movement. 
Open access e-Journal

Earth Science India, eISSN: $0974-8350$

Vol. 9 (II), April, 2016, pp. 53 - 103

http://www.earthscienceindia.info/

\section{Description of Internal Structures Sand-Mud Couplets}

These constitute the most characteristic point bar successions in the mesotidal settings of the river (Smith, 1988; Rahmani, 1988). The sand-mud couplets are clearly visible in point bar trench sections cut out during low tide. Sequence of laminae containing alternate sand and mud lies subhorizontal to slightly inclined to the point bar surface. Similar to the point bar surface, these laminae broadly reveal a convex-up configuration. The sand-mud couplets are made up of alternate thick $(2$ to $5 \mathrm{~cm})$ and thin $(0.5$ to $1 \mathrm{~cm})$ sandy laminae separated by very thin mud layers (mm-scale) or mud-drapes (Fig. 40).

Sand-mud couplets in modern tidal deposits were first reported by Visser (1980), who related its origin to the daily tidal cycles i.e. to the flood-ebb cycles. The thicker sand layers were deposited by the dominant flood tidal current and the thinner sandy layers by subordinate ebb tidal currents. The mud layers or mud drapes represent sedimentation during slack water periods (Boersma and Terwindt, 1981).

\section{Large-scale cross-beds with mud drapes and reactivation surfaces}

Point bar deposits locally show plannar tabular cross-bedding oriented landward, evidently flood oriented. These cross-bedded units (30 cm thick) indicate cross-section through megaripples and reveal a succession of tidal bundles containing reactivation surfaces, well-defined planar tabular cross-strata and mud stringers or mud laminations (Fig. 41) in response to a single tide (Boersma and Terwindt, 1981). Laterally these cross-bedded units grade to imperfectly defined cross-strata.

The reactivation surfaces represent pre-vortex structures. The foreset laminae represent full vortex structures and the mud stringers represent suspension fall out during post vortex slackening phase of a total acceleration-deceleration sequence of a single spring tide period. The imperfectly defined cross-strata that occur laterally reflect a reduced vortex activity around neap tide when the full vortex stage did not reach (Fig. 41A).

\section{Concretionary laminae alternating with fine sand laminae}

In some sections a unit of sand-mud laminations is followed underneath by isolated and coalescing sheets of concretionary (Kankar) materials within sand-mud laminae (Fig. 42). The kankar layers are laterally discontinuous and are within $3 \mathrm{~cm}$ thickness. They occur at a depth of $10-20 \mathrm{~cm}$ from the surface and their major constituents are derived from old palaeosols.

The kankar layers as channel-lag deposits are known to occur from Chambal and Jamuna River point bars, India (Reineck and Singh, 1980). Channel-lag concretionary deposits have also been described by Fisk (1944), Arnborg (1958) and Lattman (1960).

\section{Backwash Ripples}

\section{Sedimentary Structures of the Swash Platform}

These are parallel-to-river bank gentle undulations that occur away from the river channel margin. The bedform gets prominence due to variations of colour from the crests to the troughs of ripples. They are sinuous in plan; wavelength ranges from $36-62 \mathrm{~cm}$ with a mean value of $47 \mathrm{~cm}$ and height from $0.3-0.9 \mathrm{~cm}$ with a mean value of $0.6 \mathrm{~cm}$. The ripples 
are generally asymmetrical in profile with a lee-slope direction towards the river channel. Dark minerals mostly biotite concentrate along the troughs of ripples whereas light coloured quartzo-feldspathic minerals mark the ripple crests. Thus, instead of being marked by their relief these ripples are characterized by sinuous, alternate light and dark colour bands.

The backwash ripples occupy the highest topographic areas and concentrate in regions of maximum advance of wave swash within a width of $7-10 \mathrm{~m}$. The ripples disappear as the mangrove mud banks approach. The backwash ripples migrate towards the river channel by backwash movements and reveal secondary modifications following their initial formation at higher Froude number (Komar, 1976).

\section{Swash Marks}

These are tiny, curved ridges or markings on the sandy swash platform. The curved ridges with their convexity landward mark the maximum advance of wave swash. The ridges are generally of insignificant height $(<2 \mathrm{~mm})$ and show strike-wise continuation for several meters although with minor breaks at places. The ridges are generally made up of very fine sand grains.

Swash marks result from the lobate fronts of dying waves swash. In the present area the swash marks register the limit of the outer bank of the river channel and as a result their alignment is at right angles to the shoreline alignment. Hence the swash marks here occur almost at right angles to their counterparts on the sea beach.

The spacing of successive swash marks is directly dependent on the slope amount of beach or platform on which they occur (Emery and Gale, 1951; Komar, 1976). Sandy platforms with steeper slopes give rise to closer spacing of swash marks, whereas, gently sloping surfaces yield wider spacing. The spacing of swash marks in the present study area ranges from 5-20 cm and corroborates a corresponding change of slope of the swash platform from $6^{0}$ to $2^{0}$.

\section{Rill Marks}

Rill marks are dendritic erosional structures on the sandy swash platform and are made by a system of small rivulets originated from a flow of thin layer of water during falling water stage. Rill marks are of various forms and dimensions and their morphological variations are primarily controlled by local topography, slope of sediment surface, grain size and flowage of water.

Cepek and Reineck (1970) described a number of morphological varieties of rill marks of which only three varieties are quite abundant in the present study area. They are observed on slopes possessing angles of $2^{0}$ to $6^{0}$ and grain size ranging between medium sand and silt (2.4 to 5.6 phi).

\section{a) Partially Conical Rill Marks}

They appear in the form of partially developed conical depressions whose walls are sculptured by fine rills (Figure 43). The cones are around $15 \mathrm{~cm}$ across. Water drained from the conical rills to form larger rill marks (70 to $80 \mathrm{~cm}$ long) with accumulation tongues 
downslope. A sudden change in slope amount of the platform is marked by a change in the morphological variety of rill marks (Fig. 43).

\section{b) Bifurcating Rill Marks}

They often show downslope bifurcation and are generally sinuous or meandering in pattern (Figure 44). The bifurcation is often quite strong and the last bifurcations remain open in the downslope and downcurrent direction. Each of the bifurcated rill moves in a meandering fashion. These rill marks are confined to a slope angle ranging from $2^{0}$ to $3^{0}$ and run for a distance of 3 to $8 \mathrm{~m}$ on sandy platform.

\section{c) Branching Rill Marks}

These are composed of small rill systems which bundle together to form a broad channel. The rills exhibit very prominent bifurcations to yield a dendritic pattern. The direction of bifurcation is pointed upcurrent (Fig. 45). The finer rills unite together downslope and are often confined to an eroded broad channel whose walls stand 3 to $4 \mathrm{~cm}$ high from the rill floor. The rill floor is also characterized by coarser lag material of fragmental shells and mud pellets (Fig. 45). Branching rills prefer a slope angle ranging from $3^{0}$ to $6^{0}$.

\section{Rhomboid Marks}

These are rhomboderal patterns or diamond-shaped structures on the swash platform. There are two different sets of rhomboid marks which appear as superimposed large-scale and small-scale reticulate patterns on the sandy surface. The smaller set ranged from 2 to 3 $\mathrm{cm}$ along their longer diagonals and 0.8 to $1.2 \mathrm{~cm}$ along their shorter diagonals. The larger set has longer diagonals around $1 \mathrm{~m}$ and shorter diagonals around $45 \mathrm{~cm}$. Rhomboid marks have positive relief of a few $\mathrm{mm}$ to less than $1 \mathrm{~cm}$ from the normal sediment surface.

Unlike their typical occurrence on sandy beach (Hoyt and Henry, 1963; Komar, 1976), the rhomboid marks in the present study area, are formed on swash platform where their long diagonals are aligned at right angles to the longitudinal profile of the river and thus, are parallel to shoreline. Such an orientation of the long diagonals of the rhomboid marks on river mouth swash platform apparently contradicts the longer-diagonal orientations of rhomboid marks in the adjacent beach which is at right angles to the shoreline.

Rhomboid marks originate from a relatively high velocity condition of the wave backwash when the depth of water sheet is less than $1.5 \mathrm{~cm}$. They appear on the sandy platform when the wave backwash moves down leaving the area exposed (Komar, 1976).

\section{Current Crescent}

These are crescent shaped (U-or V-shaped) structures, which widen in the flow direction. In the present study area they form around dead gastropod or pelecypod shells and their arms open downslope towards the river direction. The crescents are 5-6 cm across around the moat and 8-10 cm along their arms. The tapering end of the dead gastropod shells always points downcurrent and downslope direction. 


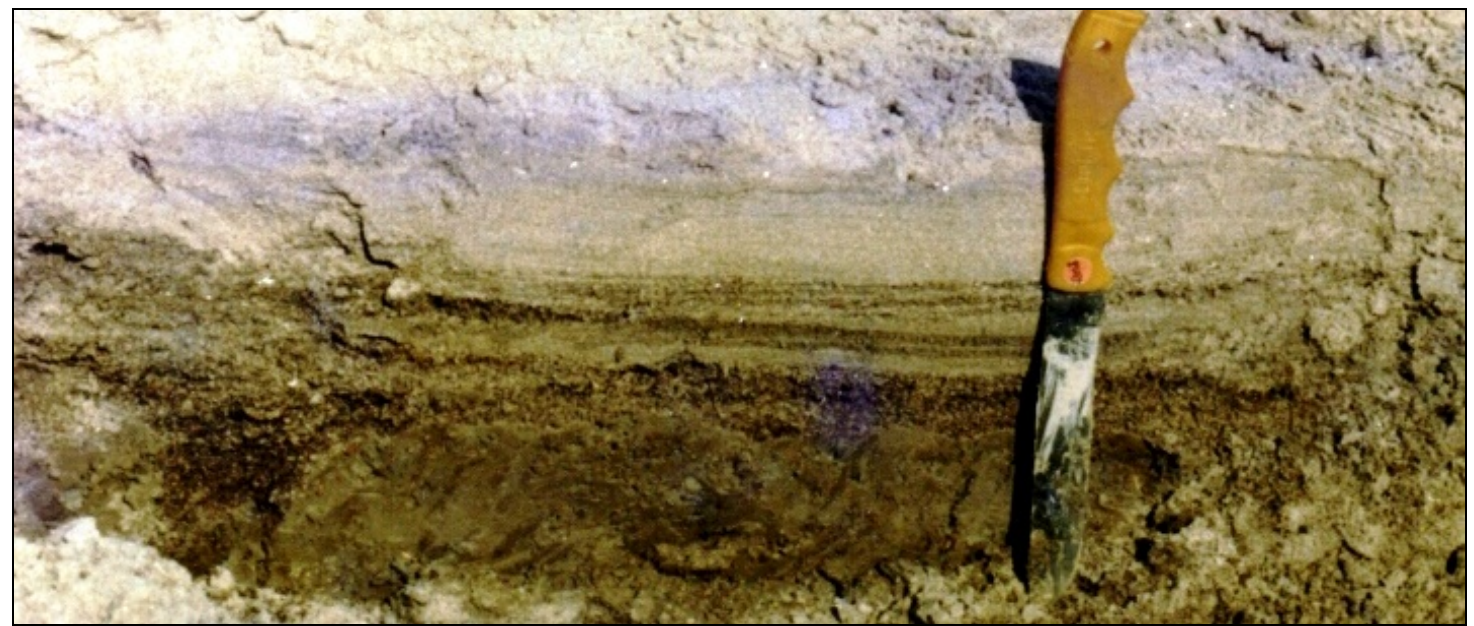

Fig. 42: Kankar (concretionary) beds at Dhanchi point bar seen at a depth of $10-20 \mathrm{~cm}$. The beds occur as isolated and coalescing sheets within alternating sand-mud laminae.

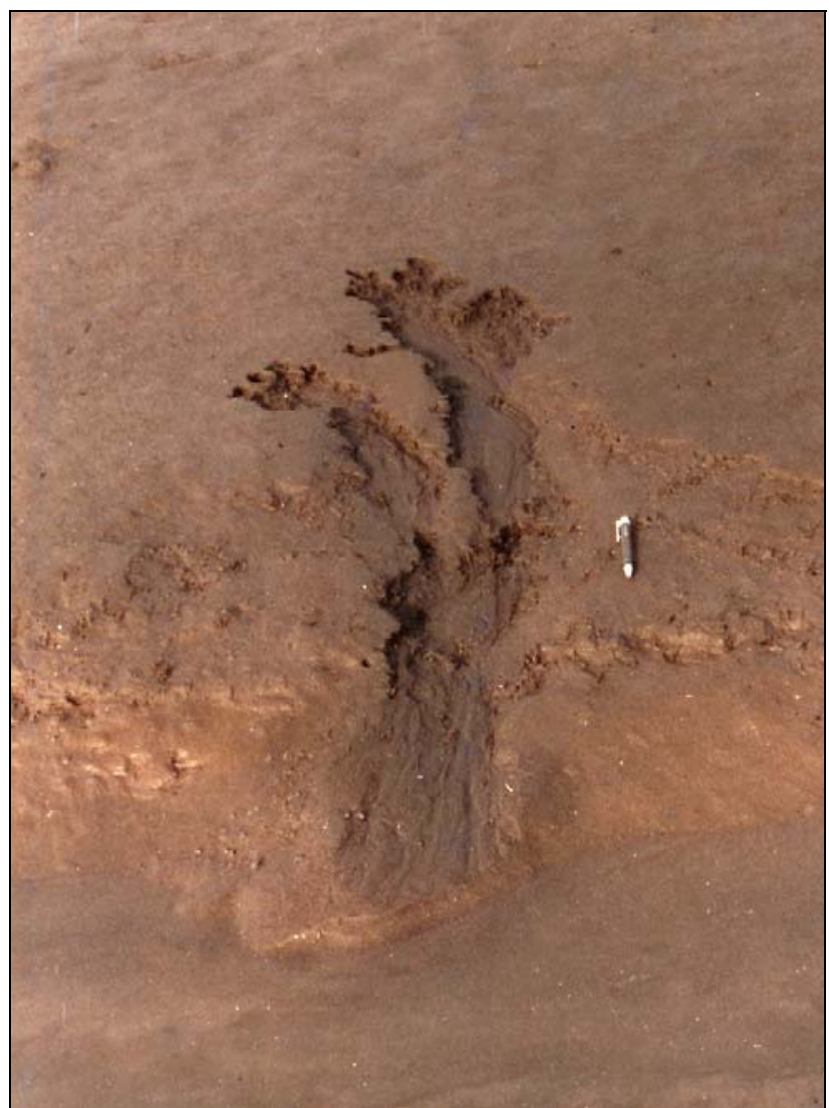

Fig. 43: Conical rill marks with accumulation tongues. Walls of pseudoconical depressions are sculptured by fine rills. Sediment eroded during rill formation is deposited at the end of the rill system in the form of a few mm thick tongues. Flow is from top to bottom. Pen is $15 \mathrm{~cm}$. 


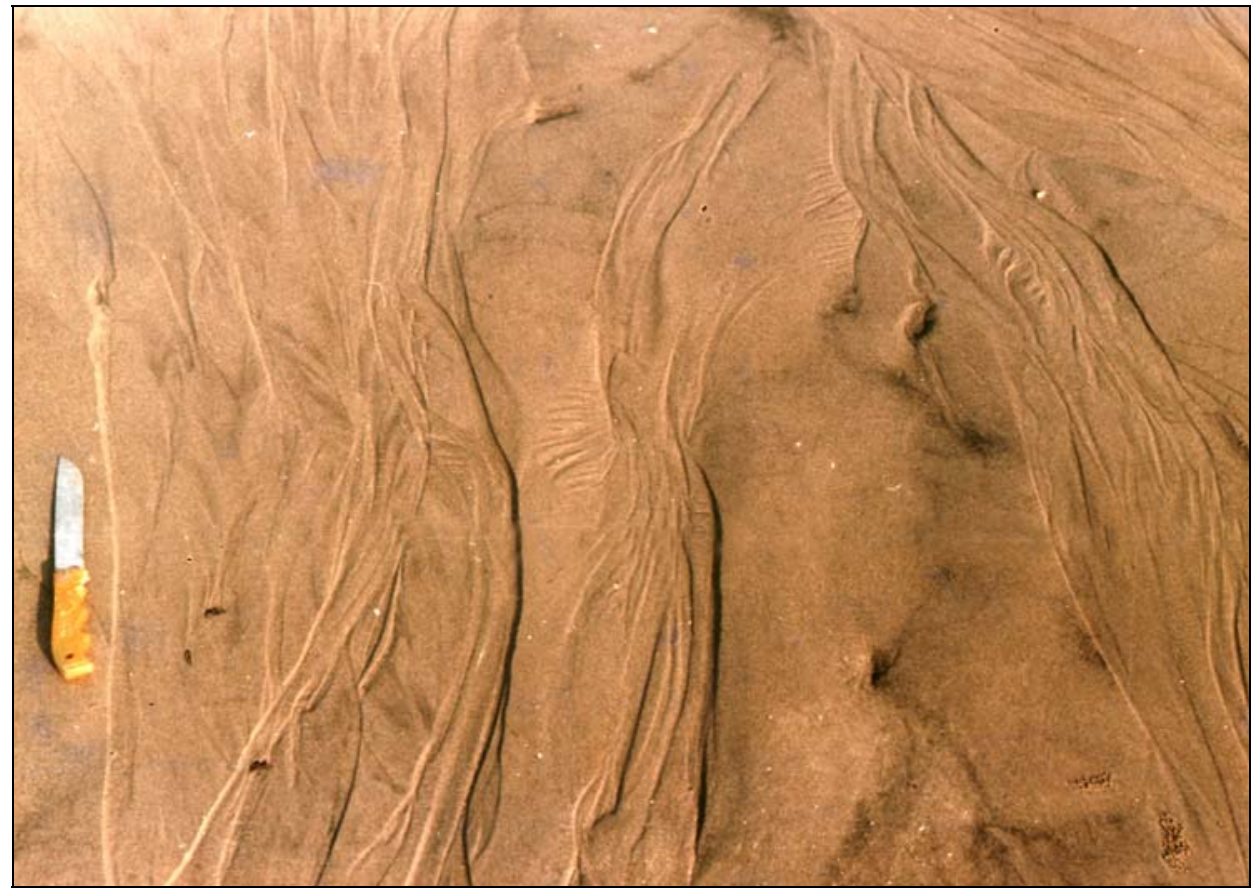

Fig. 44: Bifurcating rill marks. The rills show strong bifurcation in the down current direction. The flow is towards the observer. Knife is $26 \mathrm{~cm}$.

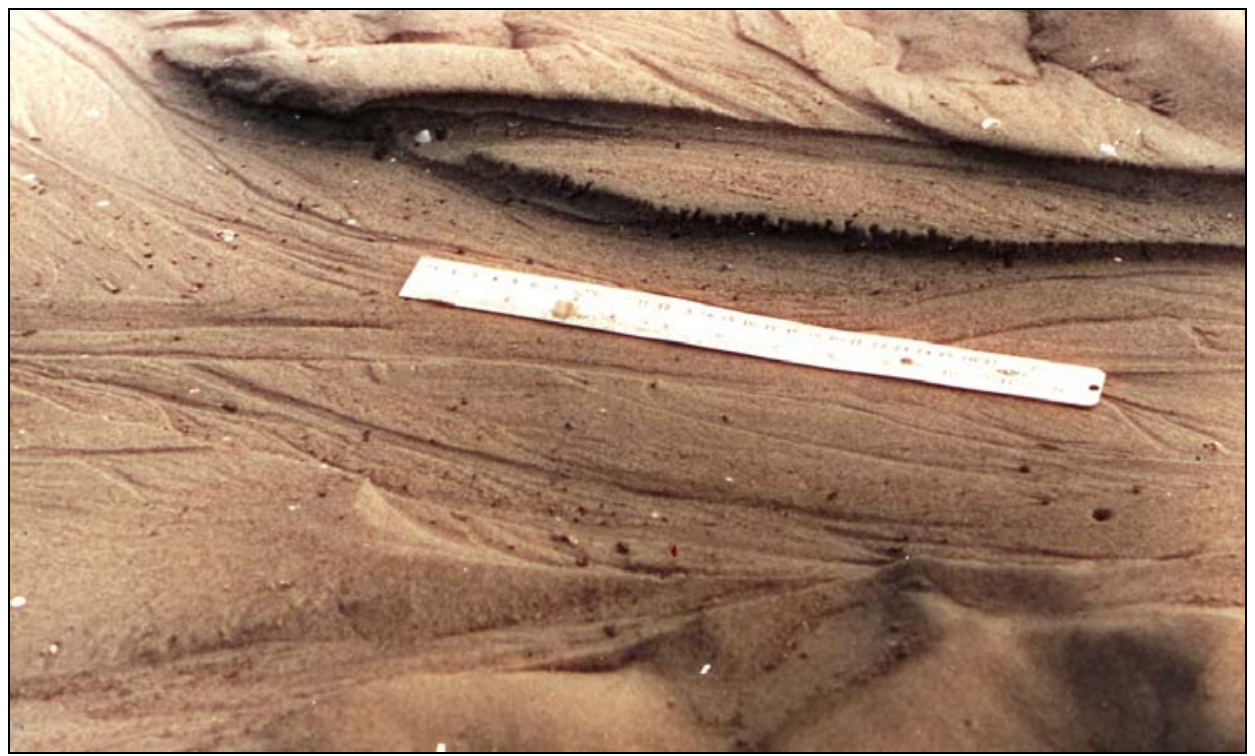

Fig. 45: Branching rill marks. Rills meet together to form a broad main channel. The flow is towards the right. Note the coarse lag materials (shell fragments and mud-pellets) on the rill floor. Scale is $30 \mathrm{~cm}$. 


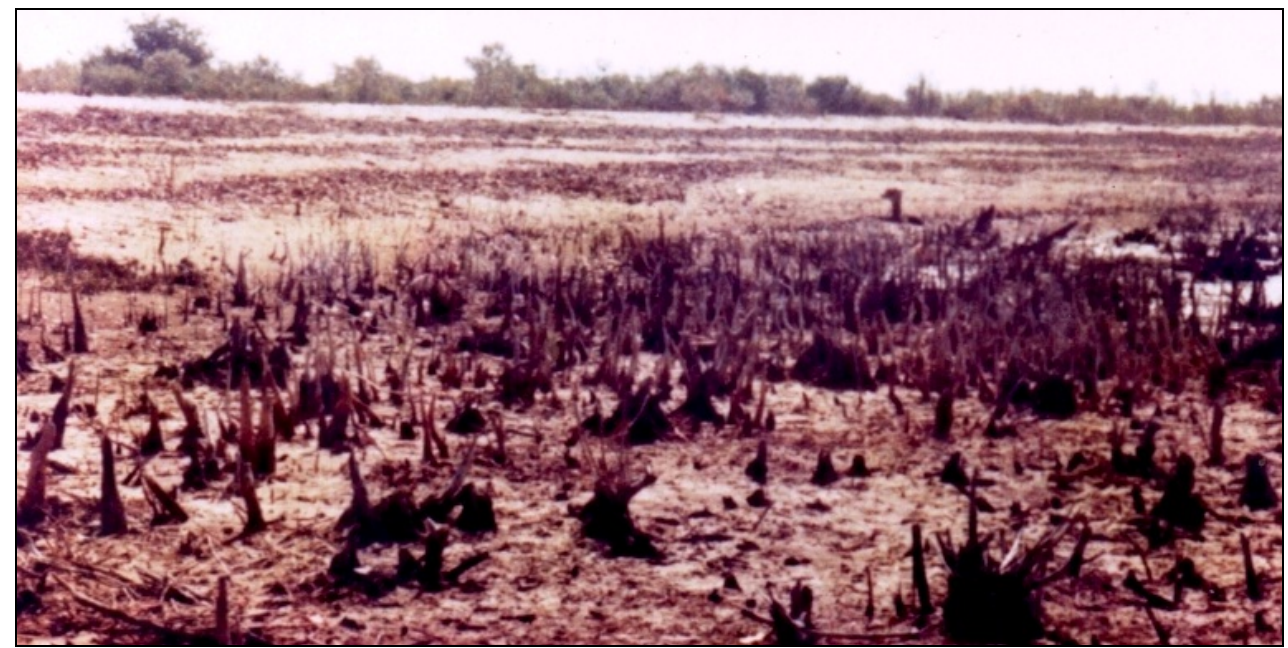

Fig. 46: The wash-over flat showing gradual seaward slope (towards bottom) near Dhanchi. The intertidal zone is with numerous mangrove trunks. Intertidal ripples are followed backward by supratidal dune field with dried up leaves in trains.

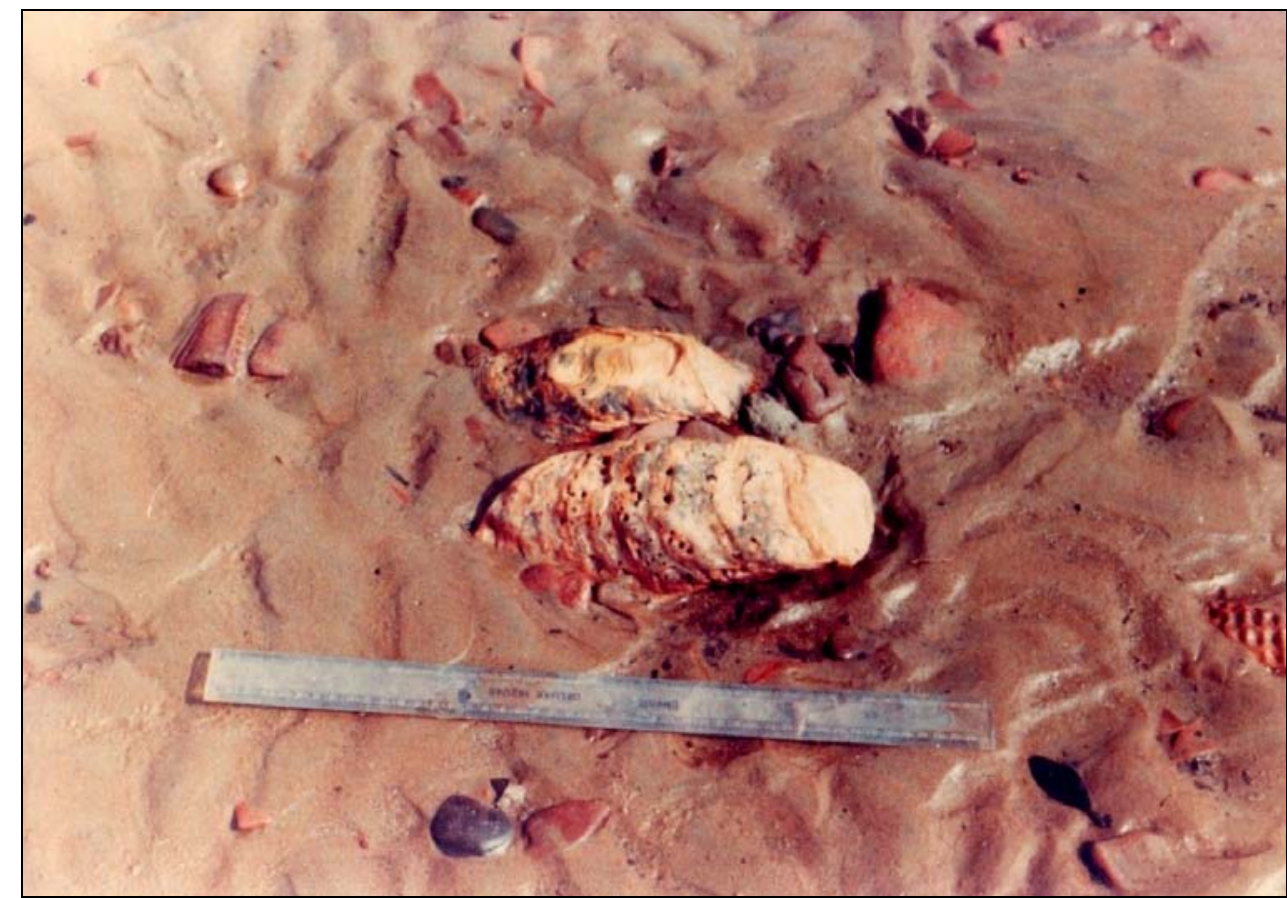

Fig. 47: Intertidal wash-over flat. Oyster shells maintain long-axes orientation parallel to current direction. The ripples (flat-topped) also indicate the same orientation. Scale is $30 \mathrm{~cm}$.

Although observed in both aqueous and Aeolian environment, current crescents (Peabody, 1947; Sengupta, 1966; Allen, 1984; and Bhattacharya, 1993) are quite abundant in the foreshore sandy beach. They form around scattered tools of permeable or impermeable bluff bodies like pellets, shell fragments, mineral matters, lithic fragments, vegetation hummock and decomposable organic matter. In addition to their preservation with these 
tools, they have recently been reported to the preserved lacking preservation of obstacles (Bhattacharya, 1992; Owen, 1994).

Current crescents in the present situation are formed from wave backwash against the dead shells strewn over the swash platform. The gastropod shells, in particular, are shifted with their tapering ends downslope due to repeated swash and backwash movement. The close association of swash marks and current crescents favours dominance of swashbackwash effect on the sandy platform. The opening direction of the arms of the current crescents, the concavity of swash marks and the tapering ends of the gastropod shells acting as tools, all point towards the downslope direction.

Summing up it may be concluded that the perpendicular-to-shoreline alignment of the bedforms like backwash ripples, swash marks, rhomboid marks and current crescents may be interpreted wrongly as beach features in rock records. Such a misinterpretation may lead to a $90^{\circ}$ error in mapping a local palaeo-shoreline.

\section{Surface Features}

\section{Sedimentary Structures of Wash-over Flat}

A wide wash-over flat at the mouth of Thakuran reveals its channel-fill origin from the geometry of internal sedimentary structures. The intertidal wash-over flat exhibits a gradual seaward slope ranging from $3^{0}$ to $6^{0}$. Further upward the surface is characterized by intertidal ripple flat backed by a supratidal aeolian flat.

The stability of the flat is maintained to a great extent by the stilt-root system of the mangrove trees, a large number of which are stripped of leaving only portions of their upright trunks (Fig. 46). Mangrove leaves, woods exotic boulder and large shells of dead oysters are strewn all over the intertidal portion of the wash-over flat (Fig. 47). The oyster shells with their long axes parallel to wave swash and backwash lie embedded on the flat surface. Fine rill marks are aligned parallel to the flow directions. The supratidal zone is marked by Aeolian dune-like features produced by accumulation of dry mangrove leaves (Fig. 48).

\section{Internal Sedimentary Structures of the Wash-over Flat}

Sedimentary units depicting a number of internal sedimentary structures have been recognized in the wash-over flat. These internal structures point to a channel-fill origin of the flat. Hummocky cross-beds generally occur at the base of the vertical sections studied and reflect a wave-induced base of the channel. Flood-generated megaripples with internal largescale planar tabular cross beds follow upward which, in turn give way to small scale ripples originated from reversing tidal currents and then to flaser beds. Sand-mud couplets of variable thickness occur at the top of most sections. A progressive decline of depositional energy is reflected in many sections. The channel-fill deposit surficially exhibits feature of wash-over flats in the intertidal zone and dune facies in the supratidal region.

Different sections cut on the wash-over flat displayed the following sequences of structural units from bottom to top:

i) A unit hummocky cross-beds, followed upward by a unit of flaser beds to sand-mud couplets (Fig. 49). 
ii) A unit hummocky cross-beds, followed upward by large-scale planar tabular crossbeds to a unit of sand-mud couplet (Fig. 50).

iii) A unit hummocky cross-bed, followed upward by flaser bedding into a unit finely laminated sand.

Minor erosional plains are often present in between the units.

\section{Hummocky Cross-stratification}

These structures are generally described as being formed by storm waves (Harms et al., 1963; Davis, 1983) at a depth of few meters from the wash-over flat surface. They are low angle $\left(2^{0}\right.$ to $\left.8^{0}\right)$ undulating cross-stratifications (Fig. 50). The lamina-sets (15-20 cm thick) are both concave and convex upward with wave length of 1 to $2 \mathrm{~m}$ and height of 6 to $15 \mathrm{~cm}$. The hummocks are often incomplete when traced laterally.

\section{Planar Tabular Cross-stratification}

The planar tabular cross-beds form an isolated set in between the underlying hummocky cross-stratifications and the overlying sand-mud laminated units. The foresets dip landward at an angle of $15^{\circ}$ to $18^{\circ}$ and thus, indicate their flood-tidal origin. The foreset laminae run for a distance of $9-10 \mathrm{~m}$ downdip. The cross-bedded units vary in thickness from $17-22 \mathrm{~cm}$ of which the individual lamina ranges in thickness from a few $\mathrm{mm}$ to 1.5 $\mathrm{cm}$. The foreset contain mud layers punctuated within sandy laminae.

The sandy planar-tabular cross-laminated unit refers to a full vortex structure originated during flood flow. The mud drapes and mud laminae punctuated within foreset laminae refer to slackening structure. The cross-bedded unit thus represents a single spring tide phenomenon. Occasionally wedge-shaped, partly decomposed mangrove trunks are locally trapped within the foreset laminae (Fig. 50 \& 52). These are drifted woody matters from nearby mangrove forests; the wood lenses are $10-12 \mathrm{~cm}$ thick centrally.

The planar cross-beds are not laterally persistent. They grade to flaser beds (Fig. 49) and further 15 - $20 \mathrm{~m}$ away into parallel-laminated units strikewise (Fig. 51).

\section{Flaser Bedding}

These are cross-stratified ripple bedding containing thin streaks of mud in the crests and troughs of ripples. Most flaser laminations in the present study area of wavy flaser type of Reineck and Wunderlich (1968) in which the mud flasers are concave upward when they occupy the crests of ripples and concave downward in the overlying ripple crests. In trench sections the flaser bedded unit is seen to continue laterally for a length of 4 to $5 \mathrm{~m}$. The mud flasers are often of some mm thickness (Fig. 49).

In general, oppositely moving flood and ebb currents with high and low water standstills are responsible to create the flaser bedding (Reineck, 1960). The wavy flasers, however, originate when each sand depositing current partially erodes the crests of the earlier-formed ripples and the mud streaks drape over them. 


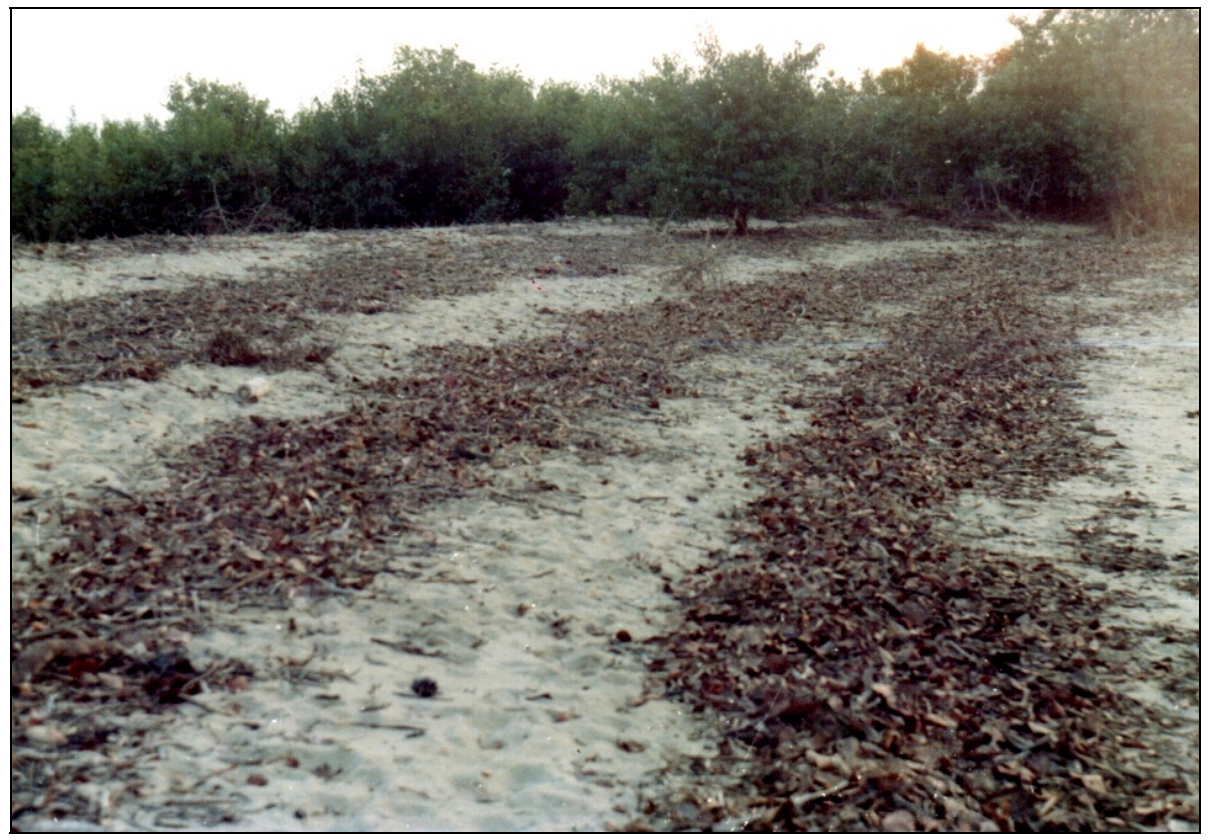

Fig. 48: Supratidal zone of the wash-over flat exhibiting dune-like trains due to accumulation of mangrove leaves.

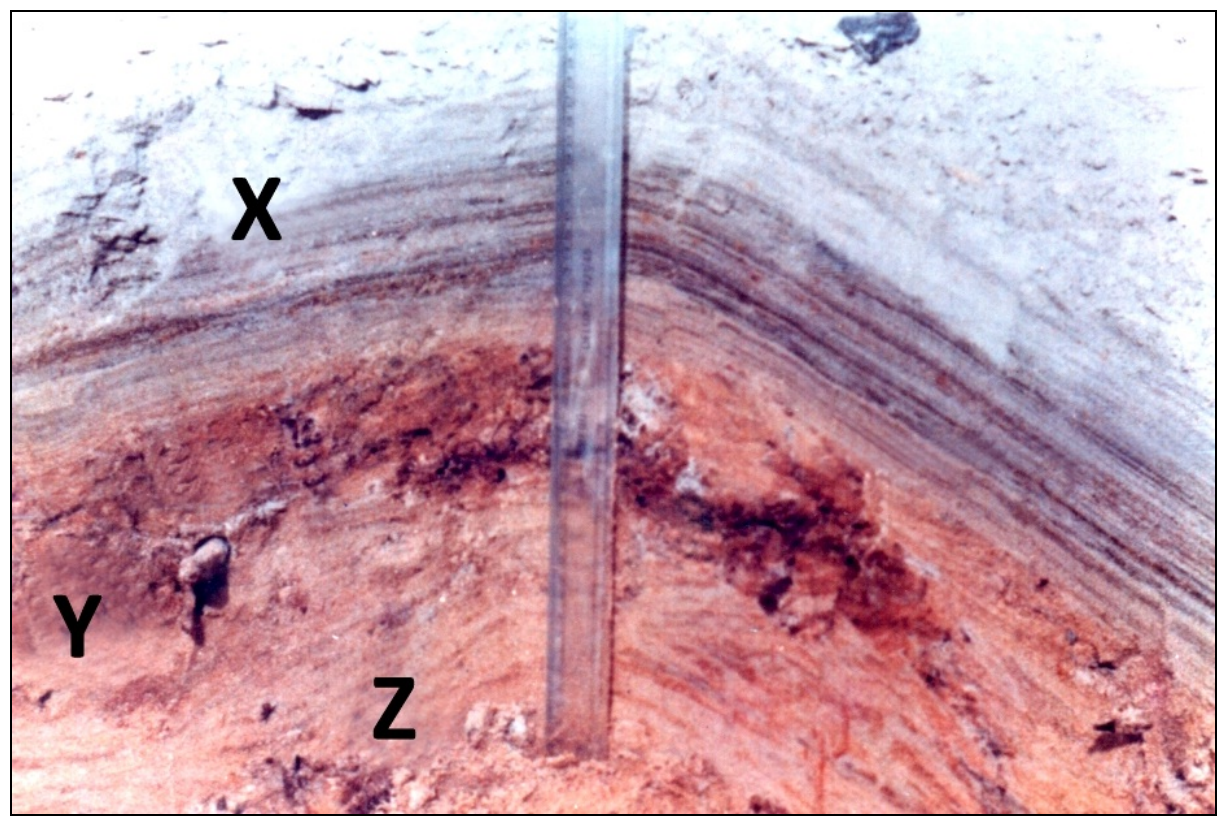

Fig. 49: A sequence of sand-mud couples with major breaks marked by mud laminae. The topmost part shows disruption of laminae due to sagging of sand from above (X). The middle unit is made up of drifted woody (mangroves) matter. The bottom of the woody zone is deformed into gentle undulations (Y). The lowermost unit reveals flaser laminations due to presence of mud lenses within sandy laminae (Z). 


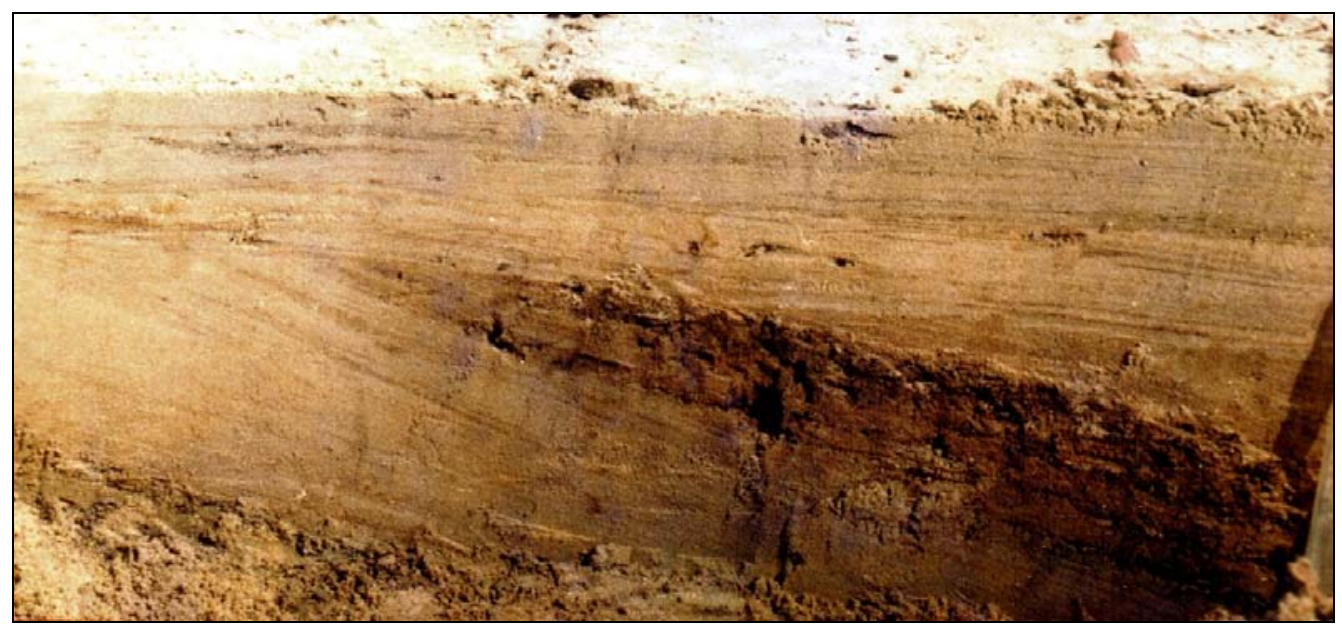

Fig. 50: Planar tabular cross-bedded unit sandwiched between overlying sand-mud alternations and underlying hummocky cross-stratifications. The foreset dips upcurrent i.e. towards the flood current. Dark zone represents woody matter. Scale is $45 \mathrm{~cm}$.

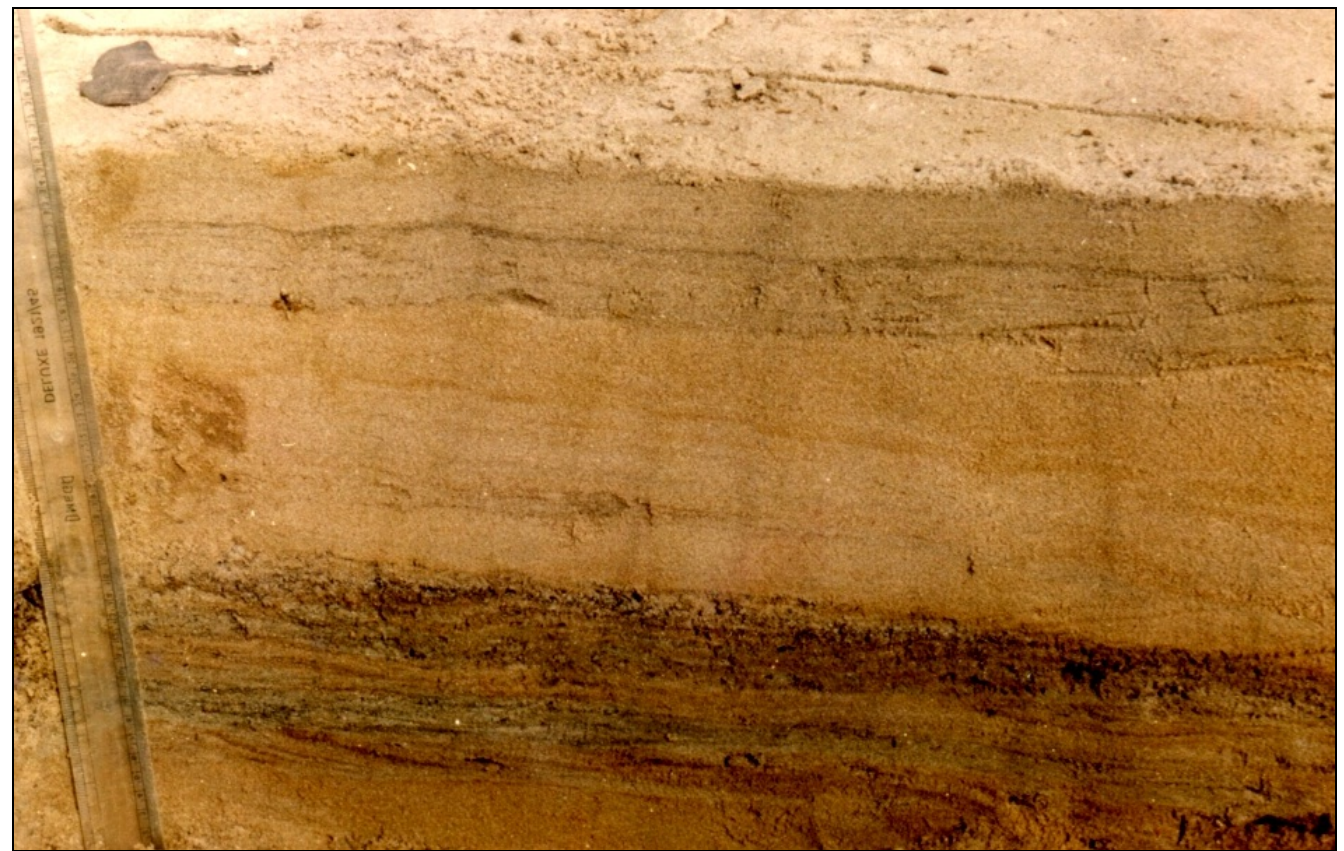

Fig. 51: Alternation of thick units $(6-10 \mathrm{~cm})$ of sand and mud observed left of the trench revealing planar tabular cross-bedded units. Muddy unit at the bottom is intercalated with thin sand lenses. 
Open access e-Journal

Earth Science India, eISSN: $0974-8350$

Vol. 9 (II), April, 2016, pp. 53 - 103

http://www.earthscienceindia.info/

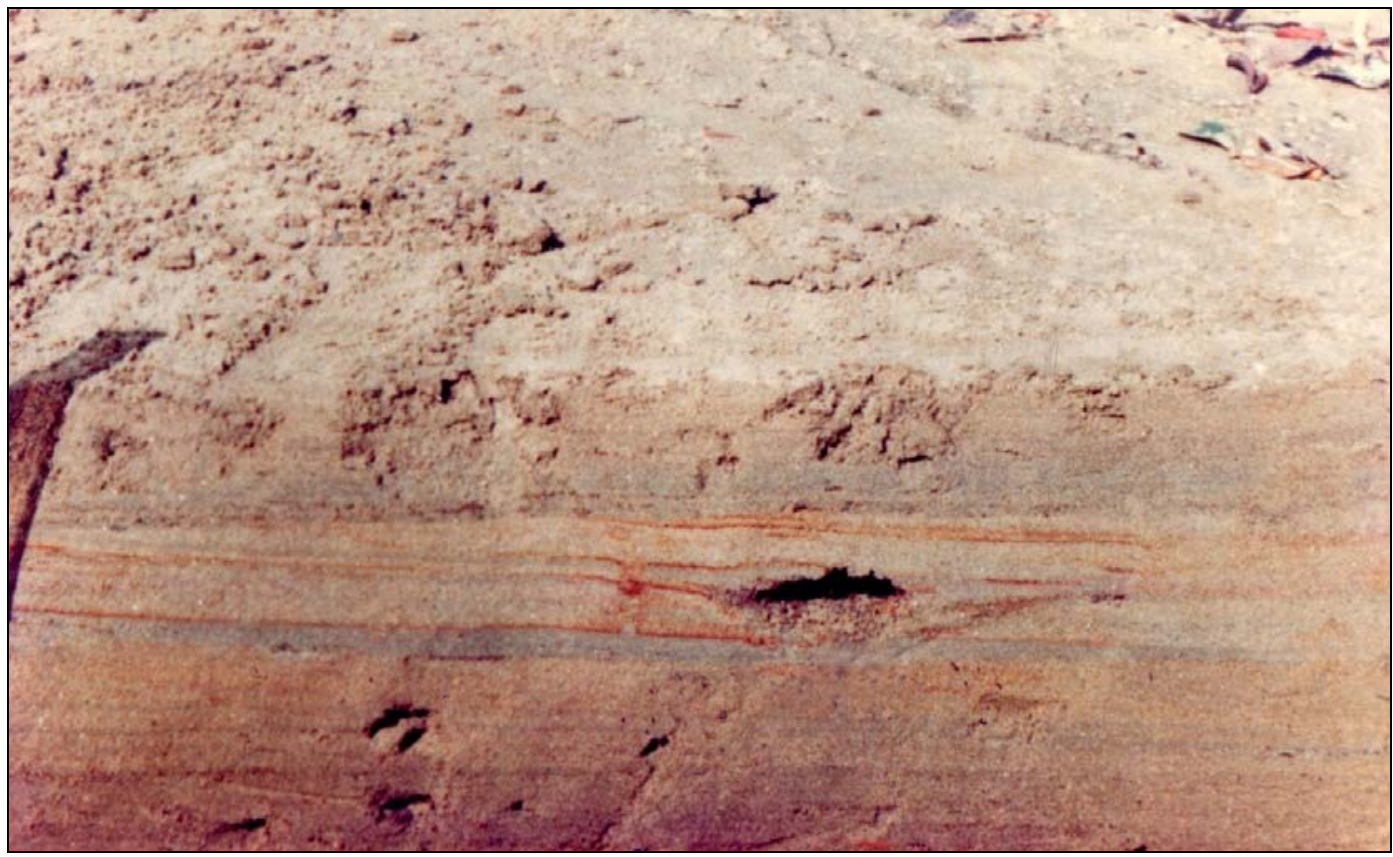

Fig. 52: Double sand-mud couplet in a trench section at Dhanchi. Sagging of laminae at the central part is due to bioturbation. A small tube opening is seen.

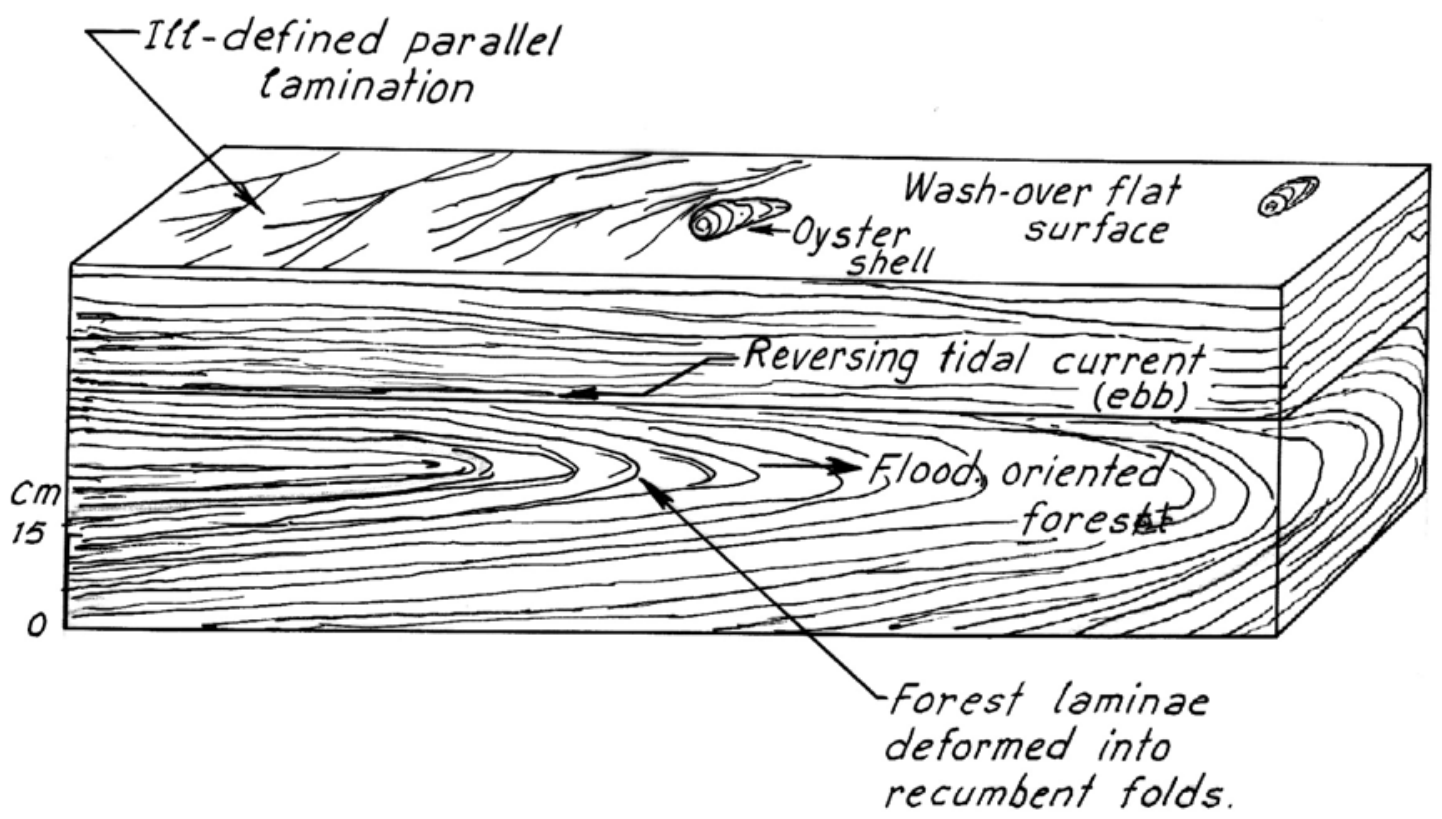

Fig. 53: Deformation of foreset laminae (Flood-oriented) into recumbent folds. 


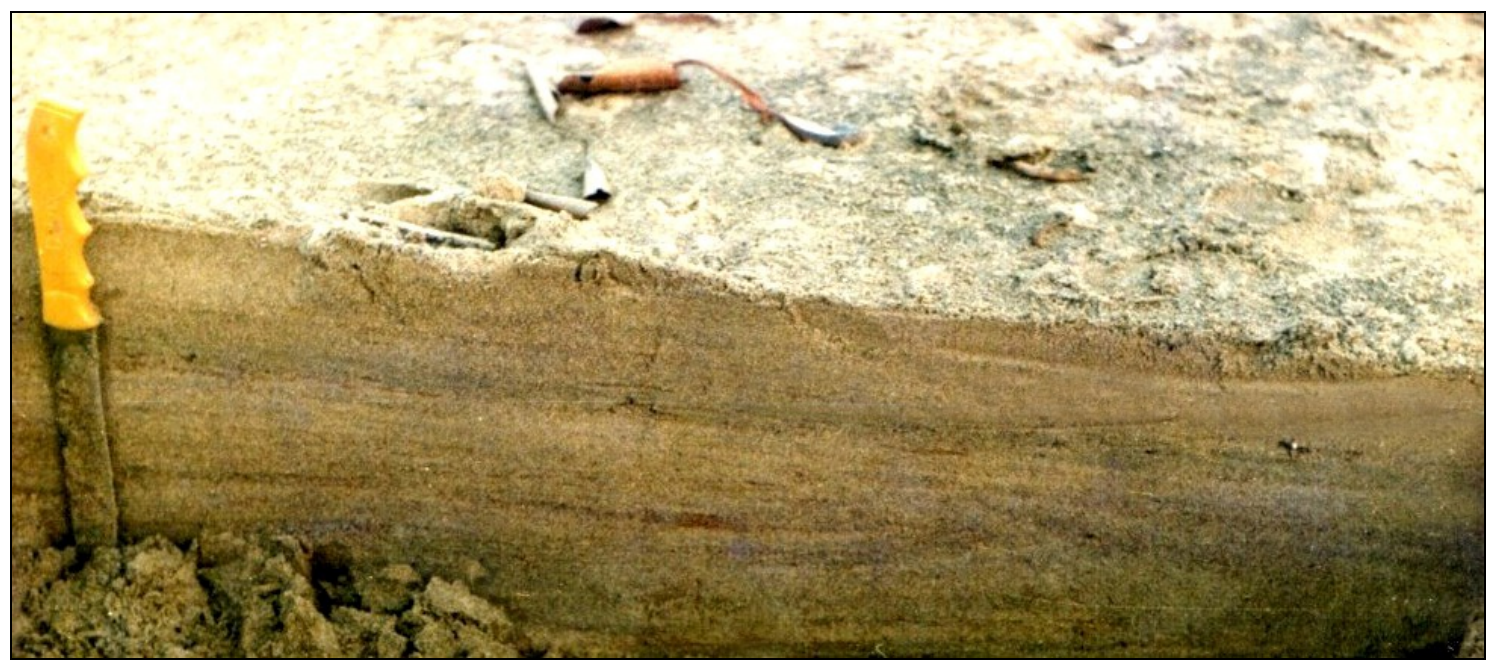

Fig. 54: Penecontemporaneous deformation structure within sandy units. The laminae are deformed into recumbent folds within two successive units when the overlying and underlying units are undeformed.

The flaser-bedded unit follows upward to interlaminated mud and sand unit towards the topmost part of the sequence.

\section{Alternate Sand-Mud Laminations}

These are horizontal to subhorizontal sets of laminae with alternation of sand and mud. The set thickness varies from $6-15 \mathrm{~cm}$ in which individual lamina is of mm-thickness (Fig. 52). Occasionally isolated small ripples are starved in the sandy laminae. The individual layers can be traced for 3 to $4 \mathrm{~m}$ laterally without any change in structure and granulometric properties.

The alternate sets of sand-mud layers represent deposition on more or less flat bottoms during slackening of wave and current energy. Occasionally, dissipation of tractive energy leaves the ripples starved (Fig. 51). The alternation of sets of sand-mud laminae gives a definite indication of the effects of tidal rhythms related to flood and ebb cycles.

\section{Deformation Structures (Soft-sediment)}

Trench sections on the wash over flat locally reveal deformation structures confined within 10 to $15 \mathrm{~cm}$ thick sandy units. These units are separated by thinner muddy layers of 1 to $2 \mathrm{~cm}$ thickness. The sandy units are very commonly interlayered with less than $1 \mathrm{~cm}$ thick mud lenses. The deformations chiefly appear as recumbent folds with closures opposite to the dip direction of the foreset laminae (Figs. 53 \& 54). The intensity of deformations often increases along dip direction of the foreset laminae.

The force of tidal currents over the water-saturated sandy cross-laminated set exerts an overriding drag effect to produce deformation of the laminae into recumbent folds. The 
flowage of material simultaneous with sliding of the bounding surfaces adds to further complications in the foreset laminae along their dip directions (McKee et al., 1962a, 1962b; Bhattacharya, 1969).

\section{Remarks on Channel Configuration and Channel-fill}

The lateral and vertical change of the internal sedimentary structures in a channel is caused, among many other reasons, by the change of bottom configuration which is deeper at the center of the channel and shallower at the margins. The large-scale planar tabular crossbeds indicate megaripple formation along the channel thalweg. This is followed sidewise by parallel-laminated units of shallower depth origin. The sand-mud alternations and flaser beds towards the top of the sequence point to their tidal current origin at the dying phase of the channel. The landward dip of the foreset laminae reflects its flood-flow origin in a channel excavated primarily by flood currents.

\section{Summary}

Sedimentary structures in tidal environments have long been utilized for interpreting the hydrodynamic conditions of their formation. The effects of macrotidal regime, moderate wave energy and long shore currents have been given due importance in this regard. The various scales of tidal cycles involving the neap-spring and ebb-flood together with wave swash and backwash impart some modifications in the bedforms.

A quasi-equilibrium state of bedform configuration arising from unsteady flow conditions is thus a common phenomenon and this study has revealed a full spectrum of bedform modification features in a macrotidal setting. Internal manifestation of bedforms is direct consequences of surface features and many of these can be earmarked as features of the tidal domain. The morphology of the bedforms studied, closely resembles those described from the Bay of Fundy, Canada and Loughor estuary, UK (Table-2). It may be concluded that the bedforms present in the field refer to a lower flow regime of the Thakuran River; the modification bedforms are useful to interpret the total range of unsteadiness in the tidal spectrum and areas of erosion and accretion can be well delineated from the morphological changes of the river bed and river banks. Depositional features typical of tidal environment like mud couplets, tidal bedding and tidal bundles have been recognized. Both ebb-flood and neap-spring cycles have been established from the preserved physical sedimentary structures.

\section{References}

Allen, J.R.L. (1968) Current ripples: their relation to patterns of water and sediment motion. North Holland, Amsterdam. 433p.

Allen, J.R.L. (1973) Phase difference between bed configuration and flow in natural environments and their geological relevance. Sedimentology, v.20, pp.323-329.

Allen, J.R.L. (1984) Sedimentary Structures, their character and physical bases. Devlopment in Sedimentology. Elsevier. 663p.

Arnborg, L. (1958) The lower part of the River Angermanalven. I Publ. Georgr Inst Univ. Uppsala, v.1, pp.181247.

Barclay, J.E. and Davies, G.R. (1989) Tidal clastic/carbonate deposits- Carboniferous Klskatinaw Formation, Alberta, and Holocene Analogue-Shark Bay, Western Australia, pp. 117-126. In: G.E. Reinson (ed.) 
Modern and ancient examples of clastic tidal deposits- a core and peel workshop. Can. Soc. Petrol. Geol. Second Int. Fes. Symp. on Clastic Tidal Deposits. Calgary, Alberta. 126p.

Bhattacharya, A. (1969) Deformed cross-beds in the point bar deposits of the River Ajay, West Bengal and Bihar. Quart J. Geol. Min. Met. Soc. India, v.VXLI(3), pp.169-171.

Bhattacharya, A. (1992) Current crescents formed by marine algae (Volania sp): a new record of obstacle marks lacking preservation of obstacles. Sedimentology, v.39, pp.513-516.

Bhattacharya, A. (1993) Backwash and swash oriented current crescents: indicators of beach slope, current direction and environment. Sedimentary Geology. V.84, pp.139-148.

Boersma, J.R. and Terwindt, J.H.J. (1981) Neap-spring tide sequences of intertidal shoal deposits in a mesotidal estuary. Sedimentology, v.28, pp.151-170.

Boothroyd, J.C. (1978) Mesotidal inlets and estuaries. In: Coastal Sedimentary Environments. RA Davies Jr (ed). pp. 287-360, Springer-Verlag, New York, 420p.

Boothroyd, J.C. and Hubbard, D.K. (1975) Coastal Engr. Res. Center. Misc. Pap. pp. 1-7. Army Corps of Engrs. Fort Belvoir. Virginia (1972), In: LE Cronin (ed.), estuarine Res. pp.217-234.

Cepek, P. and Reineck, H.E. (1970) Form and Entstehnug Von Rieselmarken in Waltnud Strrandbereich. Senekenbergiana Marit, v.2, pp.3-30.

Costello, W.R. (1974) Development of bed configurations in coarse sands. Mass Inst Tech Exper Sediment. Lab Report, v.74, 120p.

Dalrymple, R.W., Knight, R.J. and Middleton, G.V. (1975) Intertidal sandbars in Cobequid Bay (Bay of Fundy). In: LE Cronin (ed.) Estuarine Research, v.2, pp.293-307. Academic Press. New York, San Francisco, London.

Dalrymple, R.W., Knight, R.J. and Lambiase, J.J. (1978) Bedforms and their hydraulic stability relationship in a tidal environment, Bay of Fundy, Canada. Nature, v.275, pp.100-104.

Dalrymple, R.W. Knight, R.J. Zaitlin, B.A. and Middleton, G.V. (1990) Dynamics and facies model of a macrotidal sand-bar complex, Cobequid Bay-Salmon River Estuary (Bay of Fundy). Sedimentology, v.37, pp.577-612.

Das, G.K. (2016) Sedimentary Structures. pp. 568 - 572. In: Michael J. Kennish (ed.) Encyclopedia of Estuaries. Springer. 760p.

Das, G.K. (2015) Estuarine morphodynamics of the Sunderbans. Coastal Research Library. Volume 11. Springer, Switzerland. 211p.

Davis, Jr. R.A. (1983) Depositional system: a geomorphic appearance to sedimentary geology. Prentice Hall. $669 p$.

Elliot, T. and Gardiner, A.R. (1981) Ripple, megaripple and sandwave bedforms in the macrotidal Loughor Estuary, South Wales, UK. Spl Publ Int Asso Sed, v.5, pp.51-64.

Emery, K.O. and Gale, J.F. (1951) Swash and swash mark. Trans Am Geophys Union, v.32, pp.31-36.

Fisk, H.N. (1944) Geological investigation of the alluvial valley of the Lower Mississippi River. Mississippi River Commission, Vicksburg, Miss. 78p

Harms, J.C. McKnezee, D.B. and McCubbin, D.G. (1963) Stratification in modern sand of the Red River, Louisiana. J Geol, v.71, pp.566-580.

Harms, J.C. and Fahenstock, R.K. (1965) Stratifications, bedforms and flow phenomena (with example of Rio Grande). GV Middleton (ed). Primary sedimentation structures and their hydrodynamic interpretations. Soc Econ Paleont Mineral Spl Publ, v.12, pp.84-115.

Houthuys, R. and Gullentops, F. (1988) Tidal transverse bar building up to a longitudinal sand body (Middle Eocene), Belgium. pp. 139-152. In: Tide-influenced Sedimentary Environments and Facies. PL deBoer, A VanGelder and SD Nio (eds). D Reidal Publishing Company. 530p.

Hoyt, J.H. and Henry, V.J. (1963) The role of waves and tidal currents in the development of tidal inlet sedimentary structures and sand body geometry: examples from North Carolina, South Carolina and Georgia. J Sed Petrol, v.49, pp.1073-1092.

Jackson, R.G. (1975) Hierarchical attributes and a unifying model of bedforms composed of cohesionless material and produced by shearing flow. Bull Geol Soc Am, v.86, pp.1523-1533.

Klein, G. de V. (1970) Depositional and dispersal dynamics of intertidal sandbars. J Sediment Petrol. V.40, pp.1095-1127.

Klein, G. de V. (1971) A sedimentary model for determining palaeotidal range. Geol Soc Am Bull, v.82, pp.2585-2592.

Klein, G. de V. (1977) Clastic tidal facies. Champaign III. CEPCO. 149p.

Knight, R.J. (1972) Cobequid Bay sedimentology project: a progress report. Mar Sedi, v.9, pp. 45-60. 
Open access e-Journal

Earth Science India, eISSN: $0974-8350$

Vol. 9 (II), April, 2016, pp. 53 - 103

http://www.earthscienceindia.info/

Komar, P.D. (1976) Beach processes and sedimentation. Prentice Hall Inc. New Jersey. 429p.

Lattman, L.H. (1960) Cross-section of a flood plain in a moist region of moderate relief. J. Sedi. Petrol., v.30, pp.275-282.

McKee, E.D., Reynolds, M.A. and Baker, C.H. Jr. (1962a) Laboratory studies on deformation on unconsolidated sediments. US Geol Survey Profess Papers. v.450-D, pp.151-155.

McKee, E.D., Reynolds, M.A. and Baker, C.H. Jr. (1962b) Experiments on intraformational recumbent folds in cross-bedded sand. US Geol Survey Profess Papers. v.450-D, pp.156-160.

Middleton, G.V. and Southard, J.B. (1978) Mechanics of sediment movement, short course no. 3. Soc. Econ. Palaeon. Miner., Tulsa.

Owen, G. (1994) Current crescents from the Herreria Formation (Lower Cambrian) of Northern Spain. Sedimentology, v.41, pp.211-213.

Peabody, F.E. (1947) Current crescents in Triassic Moenkopi formation. J. Sedi. Petrol., v.17, pp.73-76.

Potter, P.E. and Pettijohn, P.E. (1963) Palaeocurrent and basin analysis. $2^{\text {nd }}$ ed. Springer-Verlag, New York. 423p.

Rahmani, R.A. (1988) Estuarine tidal channel and nearshore sedimentation of a Late Cretaceous epicontinental sea, Drumheller, Alberta, Canada. pp. 433-471. In: P.L. deBoer, A. VanGelder and S.D. Nio (eds.). Tide-influenced Sedimentary Environments and Facies. D. Reidal Publishing Company. 530p.

Reineck, H.E. (1960) Uber Zeitlucken in rezenten Flachsec - Sediment Geol Pundschan, v.49, pp.149-161.

Reineck, H.E. (1972) Tidal flats. In: J.K. Rigby and W.K. Hamblin (eds.). Recognition of ancient sedimentary environments. Soc. Econ. Paleon. Mineral. Spec. Publ., v.16 pp.146-159.

Reineck, H.E. and Singh, I.B. (1972) Genesis of laminated sand and graded rhythmites in storm-sand layers of shelf mud. Sedimentology, v.18, pp.123-128.

Reineck, H.E. and Singh, I.B. (1980) Depositional sedimentary environments. Springer Verlag, New York. 408p.

Reineck, H.E. and Wunderlich, F. (1968) Classification and origin of flaser and lenticular bedding. Sedimentology, v.11, pp.99-104.

Sengupta, S. (1966) Geological and geophysical studies in Western part of Bengal basin, India. Bull. Amer. Asso. Petrol. Geologists, v.50, pp.1001-1017.

Simons, D.B. and Richardson, E.V. (1961) Forms of bed roughness in alluvial channels. Proc. Am. Assoc. Civil Engr. J. Hydr. Div. pp. 87-105.

Simons, D.B. and Richardson, E.V. (1962) Resistance to flow in alluvial channels. Am. Soc. Civil Engr. Trans., v.127, pp.927-953.

Simons, D.B. Richardson, E.V. and Nordin, C.F. (1965) Sediment sorting in alluvial channels. In: Primary sedimentary structures and their hydrodynamic interpretation. Soc Econ Paleontologists and Mineralogists. G.V. Middleton (ed). Spec Publ. 12. Tulsa Okla. pp. 34-52.

Smith, D.G. (1988) Modern point bar deposits analogous to the Athabasca Oil Sands, Alberta, Canada. pp. 417432. In: Tide-influenced Sedimentary Environments and Facies. P.L. deBoer, A, VanGelder and S.D. Nio (eds). D Reidal Publishing Company. 530p.

Terwindt, J.H.J. (1988) Paleo-tidal reconstruction of inshore tidal depositional environments. In: P.L. deBoer, A. VanGelder and S.D. Nio (eds.) Tide-influenced Sedimentary Environments and Facies. D Reidal Publishing Company. 530p. pp. 233-264.

Van Straaten, L.M.J.U. (1950) Giant ripples in tidal channels. Tijdschr K ned aardrijksk. Genoot, v.67, pp.7681.

Van Straaten, L.M.J.U. (1961) Sedimentation in tidal flats areas. J Alberta Soc Petrol Geol, v.9, pp.203-213.

Visser, M.J. (1980) Neap-spring cycles reflected in Holocene subtidal large scale bedform deposits: a preliminary note. Geology, v.8, pp.543-546.

(Received:25.02.2016; Accepted: 04.04.2016) 